\title{
Beyond the Enforcement Principle: Sodomy Laws, Social Norms, and Social Panoptics
}

\author{
Ryan Goodman $\dagger$
}

Social norms scholarship offers various conceptual models for understanding law's capacity to produce or inhibit particular behaviors. The current literature, however, has inadequately attended to either testing these theories through empirical research or studying law's ancillary effects on social structure and individuals' lives. In response, this Article undertakes an empirical study of the social effects of an unenforced criminal law: sodomy statutes. The Article examines the constitutive impact these laws have on individual identity, social relations, and conceptions of public space. This aspect of the study is based on ethnographic research conducted in South Africa before and after the country's sodomy laws were abolished. The findings of this inquiry provide the empirical basis for development of a conceptual model for understanding the process by which laws intersect with informal social surveillance to produce a regime in which lesbians and gays are ultimately encouraged to discipline themselves. In developing this framework, the Article calls for integrating these understandings of micro-level social relations into a macro-sociological perspective on the regulatory effects of law. The Article thus examines the influence exerted by the criminalization of homosexuality on other institutional discourses (such as religion and medicine). These connections are

Copyright $@ 2001$ Califomia Law Review, Inc. Califomia Law Reviw, Inc. (CLR) is a California nonprofit corporation. CLR and the authors are solely responsible for the content of their publications.

$\dagger$ Bigelow Fellow and Lecturer in Law, University of Chicago Law School. J.D., 1999, Yale Law School; M.Phil., 1999, Sociology, Yale University; Ph.D. expected May 2001, Yale University. 1 wish to thank the following people for their generous advice and comments on previous drafts: Nico Besnier, Donald Braman, Edwin Cameron, Mary Anne Case, Michele Dillon, Owen Fiss, Joshua Gamson, Jack Goldsmith, Robert Gordon, Jonathan R. Nash, Eric Posner, William Rubenstein, Austin Sarat, Cass Sunstein, Ruti Teitel, Beth Van Schaack, Stanton Wheeler, James Whitman, Eric Worby, and Kenji Yoshino. 1 am also grateful for the financial and logistical support I received from the Camps Research Fund of Yale University; the Schell Center for Human Rights of Yale Law School; the Fund for Lesbian and Gay Studies; the Center for Applied Legal Studies, Johannesburg, South Africa; and the staff of the University of Chicago D'Angelo Law Library. I owe special thanks to Derek Jinks, without whose insights and generosity this Article would not have been possible. All errors are, however, my own. 
explored as one way of analyzing law's constitutive effects in shaping and remaking social norms.

\section{INTRODUCTION}

In recent years, the legal academy has experienced an "explosion of scholarly interest in [social] norms." An effort is underway to understand law's involvement in the formation, maintenance, and control of social norms and the consequent effects on individual behavior. Borrowing from the traditions of economics and sociology, ${ }^{2}$ scholars have specifically begun analyzing law's capacity to influence individuals' conduct indirectly by changing background normative signals. ${ }^{3}$ In the area of criminal law especially, leading projects have focused analytically on the "expressive function" behaviors by associating those activities with feelings of stigma and employing mechanisms of surveillance. ${ }^{6}$ These scholarly efforts have

1. Robert C. Ellickson, Law and Economics Discovers Social Norms, 27 J. Lecal STUd. 537, 542 (1998). A series of prominent symposia is a fair indicator of the growing intcllectual excitement about this subject. See, e.g., Symposium, Law, Psychology, and the Emotions, 74 CHI.-KENT L. REV. 1423 (2000); Symposium, Norms, Law, and Order in the City, 34 Law \& Soc'y Rev. 179 (2000); Soeial Norms, Social Meaning, and the Economic Analysis of Law: A Conference Sponsored by the University of Chicago Law School and the John M. Olin Program in Law and Economics, 27 J. LEGAL StuD. 537 (1998); Symposium, Law and Society \& Law and Economics, 1997 WIs. L. Rev. 375; Symposium, The Nature and Sources, Formal and Informal, of Law, 82 CoRNELl L. Rev. 947 (1997); Symposium, Law, Economics, \& Norms, 144 U. PA. L. Rev. 1643 (1996); see also Special 1ssue, Mediating Institutions: Beyond the Public/Private Distinction, 61 U. CHI. L. REv. 1213 (1994); Symposium, The Informal Economy, 103 YALE L.J. 2119 (1994).

2. See Kenneth G. Dau-Schmidt, Economics and Sociology: The Prospects for an Interdisciplinary Discourse on Law, 1997 WIS. L. REv. 389 (describing the gradual convergence of the fields of economics and sociology in legal studies); id. at 418 ("Recent work in economics and sociology shows substantial overlap in methodology and examined subject matter and thus the potential for useful exchange."); Dan M. Kahan, Between Economics and Sociology: The New Path of Deterrence, 95 Mich. L. REv, 2477 (1997).

3. See Lawrence Lessig, The New Chicago School, 27 J. Legal Stud. 661, 666 (1998) (“[1]n thc view of the new school, law not only regulates behavior directly, but law also regulates behavior indirectly, by regulating these other modalities of regulation directly."). Lessig coined the term "New Chicago School" to describe this area of scholarship. Id. at 661 . He did so on the ground that new social norms scholars generally synthesize the conventional Chicago School's economic insights with an embrace of sociological methods of inquiry. The heuristic value of Lessig's terminology, however, is subject to debate. See Transript, The New Chicago School: Myth or Reality?, 5 U. CHI. L. ScH. RoundTABLE 1 (1998) (discussing, among so-called "new" and "old" Chicago school scholars, whether Lessig's classification scheme properly applies to their work and whether there is reason to care).

4. Cass R. Sunstein, On the Expressive Function of Law, 144 U. PA. L. REv. 2021 (1996).

5. For an example of the definition and scope of the term "social meaning" as employed in the field, see Lawrence Lessig, The Regulation of Social Meaning, 62 U. CHI. L. REv. 943, 951-52 (1995) ("Any society or social context has what I call here social meanings-the semiotic content attached to various actions, or inactions, or statuses, within a particular context.").

6. See, e.g., ERIC A. POSNER, LAW AND Social Norms 88-111 (2000) (discussing "status, stigma, and the criminal law"); James Q. Whitman, What is Wrong with Inflicting Shame Sanctions?, 107 YALE L.J. 1055 (1998); Robert Cooter, Expressive Law and Economics, 27 J. Legal Stud. 585 
developed analytic models to describe law's impact, but little empirical work has been conducted to examine law's actual effects in society. ${ }^{7}$ In this regard, little is known about the collateral effects that law has in constructing individual subjects and shaping social organization through methods such as surveillance, stigma, and punishment.

On this basis, leading scholars have recently called for a significant turn within social norms scholarship: instead of merely examining law's direct influence on social meaning, scholars should also focus on ancillary social effects produced by law and should measure those effects empirically. ${ }^{8}$ In describing this needed turn, Professor Bernard Harcourt, for example, sets forth two methodological guideposts. First, scholars must examine not only the instrumental, or direct, impact of laws by evaluating their transformation of social meanings, but also the indirect or collateral effects these laws have in transforming social relations and individuals' sense of themselves:

[T] his alternative research agenda entails ... a greater emphasis on the meaning and effect of the public policies theinselves, more willinguess to question the other consequences and implications of purportedly effective policing techınques, and heightened sensitivity to the way that affected citizens think, feel, desire, judge, and relate to others. ${ }^{\text {? }}$

(1998); Dan M. Kahan, Social Influence, Social Meaning, and Deterrence, 83 VA. L. Rev. 349, 350 (1997); Dan M. Kahan, What do Alternative Sanctions Mean?, 63 U. CHI. L. Rev. 591 (1996).

7. Mark Tushnet states the problem well:

This branch of the new Chicago school can lead to some interesting questions .... However, those inquiries call for a kind of cultural investigation that seems foreign to the new Chicago school, and that would surely be better conducted through engagement with sociological and anthropological studies and theory. The emerging literature associated with the new Chicago school seems to be looking in the wrong direction, or at least at the wrong literature, for answers.

Mark Tushnet, "Everything Old is New Again": Early Reflections on the "New Chicago School," 1998 Wis. L. Rev. 579, 584; see also Amitai Etzioni, Social Norms: Internalization, Persuasion, and History, 34 LAw \& Soc'Y REv. 157, 172 (2000) ("'Robert] Ellickson's pioneering study stands out precisely because he examined the matter empirically."); $c f$. Russell B. Korobkin \& Thomas S. Ulen, Law and Behavioral Science: Removing the Rationality Assumption from Law and Economics, 88 CALIF. L. REv. 1051, 1058 (2000) ("To progress beyond the current imitial stage of scholarship, legal scholars will have to conduct more empirical and experimental work of their own to test whether these hypotheses are in fact true in the particularized settings they study.").

8. See, e.g., Bernard E. Harcourt, After the "Social Meaning Tum": Implications for Research Design and Methods of Proof in Contemporary Criminal Law Policy Analysis, 34 Law \& Soc'Y REv. 179 (2000); Tushnet, supra note 7, at 580-85.

9. Harcourt, supra note 8, at 204-05. Harcourt elaborates:

Norms-focused research must not only delve more deeply into the contested social meaning of practices such as gang membership or juvenile gun possession, it must also investigate the social meaning of the proposed policies and policing techniques.... [t]hese policing techniques .... may, in fact, reconfigure-for better or for worse-the way that we perceive, think, desire, or interrelate with others and judge others. This suggests a need to explore, beyond the effect of social meaning on behavior (especially short-term behavior), the way Id. at 182. hat these practices shape us as subjects of our time. 
Second, in order to study these collateral effects, scholars must embrace a genuine commitment to conducting empirically-based qualitative research to verify their conclusions. Harcourt describes the "need to conduct in-depth qualitative analyses.... intensive participant observation, open-ended interviews and conversations with multiple informants, and in-depth exploration of particular communities. It also calls for longitudinal studies in order to fully investigate any change in social meaning over time." 10

Taking a cue from Harcourt and others who have voiced a similar perspective, ${ }^{11}$ this Article provides a detailed analysis of the social force of criminal laws against homosexuality. Social norms scholars have often referred to sodomy laws as an example of law's expressive function. ${ }^{12}$ In one of his more recent articles on the expressive functions of law, Dan Kahan states:

[T]he expressive theory gives us the power not only to explain but also to appraise criminal law.... Sodomy laws, even when unenforced, express contempt for certain classes of citizens. The injustice of this message supplies a much more urgent reason to oppose the persistence of these rarely enforced laws than does their supposed impingement on anyone's liberty to engage in particular sexual practices. ${ }^{13}$

Notably, Kahan's statement reveals the lack of knowledge we have about these laws. While the expressive "theory" gives us some power to explain and appraise these laws, it does not examine the empirical impacts on individuals' lives and on social relations. ${ }^{14}$ Kahan's statement, however, also indicates the value in using sodomy laws as a study of law's expressive function. A detailed examination of sodomy laws offers unique insight into

10. Id. at 194; see also Bernard E. Harcourt, Reflecting on the Subject: A Critique of the Social Influence Conception of Deterrence, the Broken Windows Theory, and Order-Maintenance Policing New York Style, 97 MicH. L. REv. 291, 300 (1998).

11. Harcolurt's discussion is not completely novel. Mark Tushnet, for example, made similar arguments at a recent symposium. See generally Tushnet, supra note 7, at 580-82. Harcourt's detailed strategy for research designs and subjects of inquiry does, however, help focus this perspective for future scholarship. See also Kahan, supra note 2, at 638 (calling for integration of empirical qualitative sociological work); Korobkin \& Ulen, supra note 7, at 1058 (calling for empirical research from a social psychology perspective).

12. See, e.g., Jason Mazzone, When Courts Speak: Social Capital and Law's Expressive Function, 49 SYRACUSE L. REv. 1039, 1041 (1999) (using Supreme Court's validation of sodomy laws as example of law's expressive function); Lessig, supra note 5, at 1013 (discussing sodomy laws as one of "[t]he best examples" of laws designed to inhibit behavior that would otherwise reinforce a disfavored social meaning).

13. Dan M. Kahan, The Secret Ambition of Deterrence, 113 HARv. L. REv. 413, 421 (1999).

14. In fact, without empirical evidence to support further theoretical claims about the consequence of these laws, theorists are able to make claims only about the obvious-the law's expression of insult or contempt-stopping short of assessing the more far-reaching and material effects these laws produce. 
lav's influence on individual behavior and on social relations, even when the lav itself is unenforced. ${ }^{15}$

As of mid-1999, 86 countries still maintained criminal laws prohibiting or regulating sexual activity between consenting adults of the same sex. ${ }^{16}$ This Article examines the social effects of sodomy laws by using, as a case study, ${ }^{17}$ South Africa, a legal regime in which sodomy laws existed under similar conditions as they do in the United States, ${ }^{18}$ but where the

15. Admittedly, even if the conclusions reached by this project were limited to an unenforced law, we would still gain significant insight into law's potential to regulate the meaning of individuals' lives and social relations. Still, 1 believe there are a number of reasons why sodomy laws provide a particularly good platform for evaluating the expressive function of law more generally. First, if unenforced or radically underenforced laws yield siguificant effects, this proves perhaps the hardest case for showing law's expressive function and ancillary impacts in society, because those effects are produced without direct involvement of the criminal justice system. In other words, we can control for variables such as enforcement and actual criminal punishment. Second, sodomy laws, insofar as they are normatively offensive, serve this type of evaluation well. Norms-focused scholars commonly discuss worthwhile social norms and criminal laws that attempt to promote generally beneficent behavior (for example, scatbelt laws, anti-smoking ordinances, anti-dueling laws, and anti-littering statutes). But cf. Lessig, supra note 5, at 990 (using example of antimiscegenation laws and more ambiguous example of abortion laws). Such discussions perhaps too easily concentrate the inquiry on the instrumental aspects of making law more effective in obtaining valuable objectives, without considering collateral injuries. By analyzing sodomy laws, which most readers will likely consider distasteful and the purpose of which is connected to the promotion of deleterious social norms (punishing adults for private, consensual sexual behavior), we can suspend those other concerns of law's effectiveness and examine non-instrumental impacts of law more clearly.

16. See International Gay and Lesbian Human Rights Commission, Sodomy Fact Sheet: $A$ Global Oveniew Criminalization and Decriminalization of Homosexual Acts, at http://www.iglhrc.org/news/factsheets/sodomy.html (last visited Jan. 19, 2001); Rob Tielman \& Hans Hammelburg, World Survey on the Social and Legal Position of Gays and Lesbians, in THE THIRD Pink Book: A Global View of Lesbian and Gay Liberation and Oppression 249-342 (1993), available at http://qrd.diversity.org.uk/qrd/world/misc/worldwide.sodomy.list (Apr. 27, 1994). In the United States, Puerto Rico and eighteen states, including three of the largest (Florida, Michigan, and Texas) have sodomy statutes. See ACLU Freedom Network, Lesbian \& Gay Rights: Status of U.S. Sodomy Laws, at http://www.aclu.org/issues/gay/sodomy.html (last updated July 2000).

17. The benefits and limits of case studies have been a topic of discussion within social science literature dating back over half a century. See, e.g., Samuel A. Stouffer, Notes on the Case-Study and the Unique Case, Sociometry, Nov. 1941, at 349; George A. Lundberg, Case-Studies vs. Statistical Methods-An Issue Based on Misunderstanding, SocIOMETRY, Nov. 1941, at 379. In contemporary sociological work, case studies have become a prominent method of inquiry. WHAT Is A CASE?: EXPloRing THE Foundations of Social Inquiry (Charles C. Ragin \& Howard S. Becker eds., 1992). It is generally understood that a case study can provide information of a richness and detail not available through other research methods, but at the cost of a lack of generalizability. See NichoL.AS Abercrombie et al.. Dictionary of Sociology 41 (4th ed. 2000). The greatest epistemological advantages to case studies is in the process of theory-generation and studying preconceived notions of social relations in everyday life. See Anthony M. Orum, Introduction: The Nature of the Case Study, in A CASE For THe CASe Study 1 (Joe R. Feagin et al. eds., 1991) (discussing advantages of case studies in general and identifying those which have infuenced the generation of new theoretical models). Successful case studies can produce working propositions that scholars can then test in different settings. This Article's case study of South African sodomy laws, though limited in obvious ways to South Africa and effects of the particular laws in question, can accordingly provide insights useful to scholars interested in criminalization of homosexuality, law and sexuality issues more broadly, and law and social norms in general.

18. See infra discussion at text accompanying notes 141 \& 145-147. 
laws were recently abandoned. In 1994, South Africa became the first nation to have its constitution expressly prohibit discrimination on the basis of sexual orientation. ${ }^{19}$ Four years later, the South African Constitutional Court applied the new Constitution in striking down the country's sodomy laws. ${ }^{20}$ The value that we might glean from this aspect of the South African experience is found not only in the final legal results, but also in understanding the social background and experiences that preceded that outcome. $^{21}$

My objective in this Article is to analyze the social consequences of South Africa's sodomy laws in an effort to inform U.S. legal discussion. The project investigates, as an empirical matter, how these laws functioned, whether enforced or not, as forms of disciplinary control. I believe the conclusions reached by this study, especially because it concerns an unenforced law, can have significant implications for contemporary discussions in the legal academy and beyond.

Part I situates the present project within the relatively narrower, but directly relevant, literature concerning the consequence of criminal laws against homosexuality. I argue that the prevailing convention in current judicial and scholarly considerations of sodomy laws unduly emphasizes the fact that sodomy laws are virtually unenforced and as a consequence considers these laws relatively harmless. This analytic fixation on what I call "the enforcement principle" has inspired judicial and Iegislative complacency; the relevant legal actors (judges, law clerks, legislators, and others) are encouraged to conclude that sodomy laws do not really matter. As

19. On April 27, 1994, South Africa's interim Constitution came into force. lts "equal protection" clause included an explicit prohibition on sexual orientation discrimination: "No person shall he unfairly discriminated against, directly or indirectly, and, without derogating from the generality of this provision, on one or more of the following grounds in particular: race, gender, sex, ethnic or social origin, colour, sexual orientation, age, disability, religion, conscience, belief, culture or language." See S. AFr. Const. of 1993, $\S 8(2)$. In 1996, the final Constitution came into force, solidifying legal equality for lesbians and gays. See S. Afr. Const. (Act No. 108 of 1996), ch. 2 (Bill of Rights), $\S 9$ (3) ("The state may not unfairly discriminate directly or indirectly against anyone on one or more grounds, including race, gender, sex, pregnancy, marital status, ethnic or social origin, colour, sexual orientation, age, disability, religion, conscience, belief, culture, language and birth."). At least two other countries have recently followed suit by adopting an explicit prohibition on sexual orientation discrimination. See Ecuador Const. (1998), ch. 2 (Of Civil Rights), art. 23, § 3; FuI Const. (Constitution (Amendment) Act 1998), $\S 38(2)$. Also, a handful of national constitutions have been interpreted to contain such a prohibition implicitly. See, e.g., CAN. Const. (Constitution Act 1982), pt. I (Canadian Charter of Rights and Freedoms), $\S 15(1)$, as interpreted by Egan v. Canada, [1995] 2 S.C.R. 513; NETH. Const. (1987), art. 1; FIN. ConsT. (1999), $\S 6$. See discussion in International Gay and Lesbian Human Rights Commission, Antidiscrimination Legislation: A Worldwide Survey, at http://www.iglhrc.org/news/factsheets/990604-antidis.html (last visited March 1, 2001).

20. Nat'l Coalition for Gay and Lesbian Equal. v. Minister of Justice, 1998 (12) BCLR 1517 (CC); see also Heidi Joy Schmid, Note, Decriminalization of Sodomy Under Sonth Africa's 1996 Constitution: Implications for South African and U.S. Law, 8 CARDOZO J. INT'L \& CoMP. L. 163 (2000) (describing resolution of constitutional law issues by the South African Constitutional Court).

21. See infra Part 11.B (discussing advantages of South African case study, in particular, for examining social effects of sodomy laws). 
for the legal academy, I suggest that scholars' fixation on lack of enforcement indicates that madequate attention has been given to the reality of everyday life and the broader effects of criminal law. Scholars overlook local- and macro-level social effects and forego potentially meaningful lines of analysis on the assumption that the enforcement factor effectively nullifies the issue. Although the enforcement principle remains the dominant paradigm within legal thinking about sodomy laws, a few scholars have either implicitly or explicitly rejected its claim. I conclude Part I by describing their positions and by evaluating the points of agreement that this Article shares with their analysis, as well as the deficiencies that this Article attempts to redress.

Part II explains the methodological, theoretical, and historical foundations for the case study. Part II.A describes the traditions of sociolegal scholarship that my project embraces: empirically-based research methods and a conceptual model favoring a constitutive approach to law. ${ }^{22}$ I propose that these sociological commitments can sigmificantly contribute both to the particular legal issues discussed here and to the development of conceptual models of law's relation to social norms more generally. Part II.B describes the methodological framework, including information on my research strategy and the parameters of the study. Part II.C recites a brief history of South Africa's sodomy laws, providing an account of these laws' origin and their subsequent treatment in modern case law.

In the remaining Parts, I turn to the empirical foundation of my analysis. Part III addresses the micro-level effects of sodomy laws. Here, I present and analyze the stories of South African lesbians and gays living in the shadow of unenforced sodomy laws. Part III.A analyzes the results of interviews I conducted in South Africa while the laws were in place. Part III.B analyzes the results of follow-up interviews I conducted after the laws were invalidated. ${ }^{23}$ Based on these findings, I suggest a number of conclusions regarding the breadth and intensity of sodomy laws' micro-level social effects. At the forefront of my concerns is the process by which sodomy laws interact with public surveillance (what I call "social

22. The definition of "constitutive" scholarship is elaborated in Part I.A. For now, we can provisionally define the constitutive approach as the exammation of law's ability to produce and manage social relations and to shape individual identity. See infra text accompanying notes 107-116.

23. Hence, one of the exceptional benefits of South Africa as a case study: the abihity to conduct a longitudinal analysis of the social effects of sodomy laws before and after the laws were abolished. A textbook definition of "longitudinal research [is] a research design in which data are collected at least two different times, such as a panel study"; and a panel study is defined as "a study design in which data are collected about one sample at least two times where the independent variable is not controlled

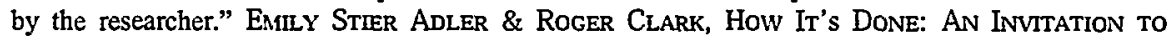
SOCIAL RESEARCH 162 (1999). The independent variable in this project's study is the invalidation of the country's sodomy laws. See also infra text accompanying notes 140-142 (explaining the longitudinal dimension of the project's field research). 
panoptics"24) in producing a regime in which lesbians and gays are ultimately encouraged to police themselves. Other conclusions relate to the ways in which sodomy laws, as symbolic statements and as threats of criminal punishment, disempower lesbians and gays in a range of contexts far removed from their sexuality (for example, in disputes with a neighbor or as victims of burglary).

Part IV addresses the influence that sodomy laws have on social norms at the macro-level. The focus is on the interaction between sodomy laws and other social institutions invested with cultural authority (such as religion and medicine). Though still keeping to the study of sodomy laws, I suggest some advantages of the constitutive approach in analyzing these phenomena, and some insights we can gain with respect to law's effects on other social institutions.

In the Conclusion, I sketch the broader implications of this study, in terms of our understanding both the constitutive and instrumental effects of law, as well as the law's expressive function. I also suggest how this project could encourage improvements in the research designs of future social norms scholarship.

\section{I}

\section{The Enforcement Principle}

In discussing the impact of sodomy laws, commentators have emphasized the question of actual enforcement. A central concern of these discussions is the formal impact resulting from criminal sanctions: whether people comply with the laws, whether arrests are made, and whether convictions occur. This fixation on the actual enforcement of sodomy laws has overlooked the myriad ways in which these laws, albeit unenforced, still matter. This Part canvasses a wide range of academic and judicial writing in order to demonstrate the enforcement principle's primacy in contemporary discussions of sodomy laws. Part I.A discusses leading commentators' explicit reliance on the enforcement principle. Part I.B discusses how other leading commentators have implicitly relied on the enforcement principle. Part I.C describes the opposition to the enforcement principle that has been raised by a few scholars.

\section{A. Explicit Reliance on the Enforcement Principle}

In Bowers v. Hardwick, the Supreme Court, by a 5-4 majority, upheld the constitutionality of a state sodomy law. ${ }^{25}$ Justice Lewis Powell's concurring opinion explicitly relied on the enforcement principle. In so

24. This term is not my own. It is borrowed from Michel Foucault's concept of "panopticisms." See infra text accompanying notes 208-2I3.

25. 478 U.S. 186 (1986) (holding that Georgia's sodomy statute does not violate the Fourteenth Amendment right to privacy). 
reasoning, he failed to comprehend the symbolic significance and material implications of sodomy laws. In the course of admitting his apprehension in giving the majority its fifth vote, ${ }^{26}$ Justice Powell offered, as a consolation, the prospect that a future suit could be brought under the Eighth Amendment's prohibition against cruel and unusual punishment, assuming that there was actual enforcement:

This is not to suggest, however, that respondent may not be protected by the Eighth Amendment of the Constitution. The Georgia statute at issue in this case... authorizes a court to imprison a person for up to 20 years for a single private, consensual act of sodomy. In my view, a prison sentence for such conduct-certainly a sentence of long duration-would create a serious Eighth Amendment issue. Under the Georgia statute a single act of sodomy, even in the private setting of a home, is a felony comparable in terms of the possible sentence imposed to serious felonies such as aggravated battery... first-degree arson ... and robbery.

In this case, however, respondent has not been tried, much less convicted and sentenced. ${ }^{27}$

By singularly focusing on the "end points" of criminal law such as prosecution, conviction, and sentencing, Justice Powell relied on erroneous assumptions regarding the impact of sodomy laws. His concern over measuring the length of jail time, as well as whether a trial and conviction took place, ignored other personal harms exacted by sodomy laws, whether enforced or not. Justice Powell explicitly found solace in the rationale that the laws were, after all, unenforced:

It was conceded at oral argument that, prior to the complaint against respondent Hardwick, there had been no reported decision involving prosecution for private homosexual sodomy under this statute for several decades. Moreover, the State has declined to present the criminal charge agaimst Hardwick to a grand jury .... The history of nonenforcement suggests the moribund character today of laws criminalizing this type of private, consensual conduct. $^{28}$

Behind the scenes, Justice Powell apparently vacillated about the constitutional question and, based on later reports, it seems the issue of enforcement is what settled his mind..$^{29}$ During the Justices' conference following oral argument, he told his colleagues that he would vote in favor

26. Id. at 197 (Powell, J., concurring).

27. Id. at $197-98$

28. Id. at $198 \mathrm{n} .2$ (citation omitted).

29. Al Kamen, Powell Changed Vote in Sodomy Case: Different Outcome Seen Likely If Homosexual Had Been Prosecuted, WASH. Post, July 13, 1986, at A1. 
of striking down the sodomy statute. ${ }^{30}$ Later, however, he switched positions. For him, the "critical factor" was the fact that Hardwick had not actually faced prosecution. ${ }^{31}$ After retirement, Justice Powell was asked whether he regretted any decision he had made while on the bench. Bowers was a "close call," "32 he explained, "1 think 1 probably made a mistake in that one." "133 Yet, he added that he considered this a matter "of little or no importance" "because the statute had not been enforced for decades. ${ }^{34}$ Notably, members of the mainstream press who reported Justice Powell's admission also followed suit by agreeing with his assessment that the decision did not damage anyone directly because the statute was never enforced..$^{35}$

In the judiciary, Justice Powell is not alone in his disregard of sodomy laws' expressive effects. Judge Richard Posner adopts a similar position in his discussion of the social impact of sodomy laws. Using a law and economics framework, Posner performs a cost-benefit analysis of sodomy statutes in assessing the laws' efficacy and social costs. ${ }^{36}$ After evaluating the competing concerns as he views them, Posner concludes that sodomy laws are inefficient and therefore lack rational justification. ${ }^{37}$ According to Posner, however, because sodomy laws are unenforced, there is no real damage inflicted and, consequently, no urgency in eliminating such legislation:

The analysis ... seems to me decisive in favor of repealing laws punishing homosexual acts between consenting adults. Not that repeal will do many homosexuals much good. The enforcement of these laws has become exceedingly rare. It is better not to have laws on the books that reflect ignorance and prejudice; but if they

30. Id.

31. Id.

32. Ruth Marcus, Powell Regrets Backing Sodomy Law, WASH. Post, Oct. 26, 1990, at A3.

33. Ethan Bronner, Ex-Justice Powell Has $2 d$ Thoughts on Sodomy Case, Boston Globe, Oct. 26,1990 , at 3 .

34. Michael S. Slawin, You Be the Judge in Your Own Home, St. Louis Post-DisPatch, Nov. 13, 1990, at 3C (Letters to the Editor); Marcus, supra note 32.

35. See, e.g., Bronner, supra note 33 ("While the case has had little direct impact-no one has been arrested under the Georgia law since-it was of great significance for the doctrine of constitutional privacy.").

36. Richard A. Posner, The Economic Approach to Homosexuality, in SEx, PrefFerence, AND FAMILY 173 (David M. Estlund \& Martha C. Nussbaum eds., 1997) [hereinafter Posner, The Economic Approach]; Richard A. Posner, Sex and Reason 14 (1992) [hereinafter Posner, Sex and Reason].

37. Posner, The Economic Approach, supra note 36, at 178-79; PosNER, SEX AND REASON, supra note 36 , at 309, 441. Posner acknowledges that his model leaves room for substantial improvement, and notes that further investigation is specifically needed to estimate "the effect of the current legal disabilities on the practices of homosexuals." Id. at 293. This Article takes up Posner's charge in a broader sense. That is, my discussion investigates, not simply "homosexual" practices as Posner's remarks suggest, but the various effects that sodomy laws have on a wide range of experiences of lesbian and gay individuals. 
are not enforced, they do little harm, despite much lore to the contrary. ${ }^{38}$

To illustrate his position, Posner states that sodomy laws should generate the same lack of concern as now defunct laws prohibiting adultery. ${ }^{39}$ In more general terms, he describes such "unenforced or radically underenforced laws" as "dead letters." 40 Posner's evaluation of the social impact of sodomy laws is deceptively simple: since no one is arrested or jailed, no one is seriously injured. Analyzed in these terms, his prescription for judicial and legislative complacency appears quite reasonable.

A number of legal scholars have similarly disregarded the material impact of sodoiny laws. Some of these scholars embrace the enforcement principle, focusing their attention on the social costs of sodomy laws that are unrelated to direct material harms. Nan Hunter, for exainple, submits: "Nor will [Bowers] have a direct, immediate impact on day-to-day life-again, unlike a decision eliminating legal abortion, or inviting coercion of confessions, or ending desegregation plans." ${ }^{\prime 41}$ Hunter argues that the impact of Bowers is "in its language and its social meaning as a symbol. ${ }^{242}$ In making a related argument, Timothy Reimig also accepts the enforcement principle. ${ }^{43} \mathrm{He}$ states: "Even though sodomy laws have had little practical consequences, their emotive force for large sections of society perpetuate (sic) their existence."44 Reimig proceeds to argue that sodomy laws function as an expression of insult by anti-gay members of the public. ${ }^{45}$ These symbolic effects have important consequences, ${ }^{46}$ but

38. Posner, Sex ANd Reason, supra note 36, at 309 (citation omitted). It is unclear what Posner means by "much lore to the contrary." He follows this statement by citing and criticizing, at length, propositions against criminalizing homosexuality from a book written in the 1960s. Id. at 309-10 (discussing Herbert L. Packer, The Limiss of the Criminal Sanction 304 (1968)).

39. Id. at 292 .

40. Id. at 4 .

41. Nan D. Hunter, Banned in the U.S.A.: What the Hardwick Ruling Will Mean, in SEX Wars: Sexual Dissent and Political Culture S0, 81 (Lisa Duggan \& Nan D. Hunter eds., 1995).

42. Id.

43. Timothy W. Reinig, Comment, Sin, Stigma \& Society: A Critique of Morality and Values in Democratic Law and Policy, 38 Buff. L. Rev. 859 (1990).

44. Id. at 865 .

45. Id. at 866 . The thrust of Reinig's constitutional argument against sodomy laws is that they violate the First Amendment's prohibition against government-sponsored religion. See id. at 894 . Reinig claims that "[s]odomy statutes have as their principal effect a perception in society that government officially approves of certain religious doctrines conceming the immorality of gay sexuality." Id. at 897-98 (emphasis added). In making this point, he first emphasizes sodomy laws' lack of enforcement to demonstrate that they do not serve other purposes. See id. at 863,865 . He then casts sodomy laws' function and effect in terms of their "mere symbol" and expression of an invective. See, e.g., id. at 866,901 .

Reinig also suggests that sodomy statutes and other anti-gay laws generate societal stigma which, in turn, limits lesbians' and gays' participation in the democratic process. See id. at \$94. This Article obviously shares more in common with that aspect of Reinig's argument. Reinig, however, does not develop how this claim relates to sodomy laws in particular. I, therefore, address such political process 
Hunter and Reinig's arguments unnecessarily avoid consideration of the direct, material effects of sodomy laws in individuals' daily lives.

Richard Mohr makes a similar analytic move in his book Gays/Justice, ${ }^{47}$ a work that has been touted as "certain to become a classic of gay political thought." ${ }^{98}$ In general, Mohr presents a cogent assessment of the condition and prospects of lesbian and gay rights. His analysis of sodomy laws, however, goes astray when it agrees with the enforcement principle. Mohr first accepts as common knowledge that sodomy laws rarely, if ever, land anyone in jail. ${ }^{49}$ On this basis, he claims that the best argument for repudiating sodomy laws must come from admittedly abstract theories of dignity. Mohr submits that the laws' condemnation of homosexual behavior constitutes an insult to lesbians and gays. ${ }^{50}$ Mohr states: "[S]odomy laws are the chief systematic way that society as a whole tells gays they are scum."

Mohr, however, presumes that few individuals, whether lesbian, gay, straight, or bisexual, ever know that sodomy laws exist, ${ }^{52}$ a fact he believes reduces his argument to largely nonmaterial harms. ${ }^{53}$ Ultimately, his position collapses into an abstract, quasi-deontological principle. On the ground that hardly anybody knows about the laws, Mohr expressly rejects the idea that sodomy laws impose material effects, such as psychological damage or unhappiness, on lesbians and gays. ${ }^{54}$ Instead, Mohr reasons that lesbians and gays, "even if unaware of sodomy laws, are insulted behind their backs by them. Even if some gays are unaffected by them in the sense that their happiness or fortunes do not depend upon the laws' removal,

arguments in the following section as they are more fully developed, and persuasively presented, in Janet Halley's work. See infra Part 1.C.

46. As mentioned earlier, see supra note 14, while I agree that sodomy laws symbolically convey a message of insult or contempt, that sort of analysis stops woefully short of understanding the material consequences these laws produce, such as the ways individuals regulate their behaviors in response to the law, the unanticipated influences on local social relations, and the macro-level effects in the social regulation of sexuality.

47. Richard D. Mohr, Gays/Justice: A Study of Ethics, Society, and Law (1988). Reinig borrows directly from Mohr to make his point that, although unenforced, sodomy laws are a means of expressing an insult. See Reinig, supra note 43, at 866.

48. Ian Kramer, Book Note, Gays/Justice: A Study of Ethics, Society and Law, 91 Colum. L. REV. 1259, 1260 (1991).

49. MoHR, supra note 47 , at 51 .

50. Id. at 57 .

51. Id. at 60 .

52. Id. at 53-54. My project disputes Mohr's premise that people are largely unaware of the existence of sodomy laws. One likely explanation for the disagreement is that media attention and the mobilization of the gay rights movement have significantly raised the level of awareness of these laws since Mohr published his book. Regardless of this explanation, Mohr does not cite any empirical research to support his conclusion, and the interviews I discuss in Parts IlI and IV contradict Mohr's claim.

53. Id. at 57-59.

54. Id. at 53-54. 
nevertheless their dignity is diminished by the laws' very existence."s5 Mohr admits that his argument from dignity is "an elusive notion, often appealed to when people have run out of moral reasons and explanations." 56 However, in reaching this unsatisfying result, he fails to consider whether his commitment to an initial premise, the enforcement principle, was possibly misguided. If he had challenged the underlying logic of the enforcement principle, or investigated whether people knew about sodomy statutes and how they reacted to the statutes, Mohr could have provided a better assessment of the material harms produced by such laws.

Mohr's book was one of the first discussions of sodomy laws following Bowers, and it still retains significant influence in academic circles. In a 1995 article, Professor Donald Dripps subscribes to a position much like Mohr's. ${ }^{57}$ Dripps adopts the position that sodomy laws have no practical effect beyond the power of symbolic statements. In fact, he takes this as the consensus view: "Defenders and detractors agree that the essential significance of sodomy laws is symbolic. They remain on the books in half the states, but are nowhere enforced with respect to private, consensual acts." 58 Dripps considers measuring neither the social effects of the symbolic nature of the law nor the more direct ways in which individuals might manage their lives in relation to the laws. Rather, his argument is limited to minimizing the material impact of sodomy statutes.

Dripps expands on Mohr's position that sodomy laws have no material effects by arguing that because sodomy laws have no real impact, cases such as Bowers lack judicial standing. ${ }^{59}$ The motivation behind his project is an admirable attempt to encourage judges to limit Bowers to its facts. Nevertheless, his conclusions, like Mohr's, rely on the flawed (and dangerous) premise that sodomy laws do not materially impact people's lives. Dripps's characterization of sodomy laws makes these laws seem defunct and inconsequential: "Nor could Hardwick complain of the threat of future prosecution, because all knew that the charge against him was a unique aberration from a deliberate pattern of nonenforcement. The vote of the

55. Id. at 60.

56. Id. at 57 .

57. Donald A. Dripps, Bowers v. Hardwick and the Law of Standing: Noncases Make Bad Law, 44 EMORY L.J. 1417, 1442 (1995); see also id. at 1424 n.28 (citing MoHR, supra note 47, at 52-62). Also, Reinig's article is replete with citations to and quotations from Mohr. See, e.g., Reinig, supra note 43 , at $862-63,865-66,889,901$.

58. Dripps, supra note 57, at 1442.

59. On the issue of standing, Dripps's suggestion runs counter to the strategy of many litigators in the field. Attorneys for Lambda Legal Defense and Education Fund have been arguing for broader recoguition of the impact of sodomy laws, otherwise judges are quick to dismiss challenges against sodomy laws for lack of standing. See Evan Wolfson \& Robert S. Mower, When the Police Are in Our Bedroonis, Shouldn't the Courts Go in After Them?: An Update on the Fight Against "Sodomy" Laws, 21 FoRDHAM URB. L.J. 997, 1002-1009 (1993) (reproducing amicus curiae brief by Lambda). 
Justices did not cost any party to the case anything." ${ }^{60}$ Dripps generalizes his conclusion to an assessment about the lives of gay men as a whole: "[I]f the Atlanta authorities were bent on enforcing the statute, hive cases of actual prosecution would very shortly reach the courts. If the Atlanta authorities were bent on not enforcing the statute, there would be no threat to gay men as a class." ${ }^{61}$ Bowers, according to Dripps, should not even be considered "a real case."62 In short, Dripps's work gives added support to Mohr's position and explicitly encourages wider acceptance of the enforcement principle in judicial reasoning about sodomy statutes.

\section{B. Implicit Reliance on the Enforcement Principle}

While the foregoing commentators explicitly rely on the enforcement principle, other scholars do so implicitly. In particular, although some legal scholars have offered broad theoretical reformulations for analyzing sodomy laws, the enforcement principle still retains a hold over their work. In this section, I consider two leading articles in order to demonstrate the enforcement principle's subtle influence on other important areas of scholarship: Jed Rubenfeld's The Right of Privacy ${ }^{63}$ and Kendall Thomas's Beyond the Privacy Principle. ${ }^{64}$

Rubenfeld's project proposes a fundamental reconceptualization of the constitutional right to privacy and, in doing so, relies on a theory of enforcement that proves inadequate when applied to sodomy laws. Rubenfeld's argument is that the constitutional right to privacy should be construed not by asking what the law prohibits, but rather what the law produces in compelling individuals to behave according to its dictates. ${ }^{65}$ Rubenfeld's project implicitly adheres to the enforcement principle by depending on the assumption that enforcement works and by concerning only the implications of compliance. ${ }^{66}$

60. Dripps, supra note 57 , at 1417.

61. Id. at 1428 .

62. Id. at 1436 ; see also id. at 1437.

63. Jed Rubenfeld, The Right of Privacy, 102 HaRv. L. Rev. 737 (1989).

64. Kendall Thomas, Beyond the Privacy Principle, 92 Colum. L. Rev. 1431 (1992).

65. Rubenfeld provides a succinct description of the argument:

Suppose instead we began by asking not what is being prohibited, but what is being produced. Suppose we looked not to the negative aspect of the law-the interdiction by which it formally expresses itself-but at its positive aspect: the real effects that conformity with the law produces at the level of everyday lives and social practices.

Rubenfeld, supra note 63, at 783.

66. Rubenfeld relies on Foucault for his impetus to examine the practices and identities that laws produee. Id. However, Rubenfeld adopts a conventional understanding of the mechanisms of enforcement by which laws result in those social practiees. He explains that his alternative approach to privacy is based on an "anti-totalitarian principle," $i d$. at 787, 794-96, a description which corresponds with a traditional view of state imposition of authority. Arguably, Rubenfeld must adopt this traditionalist perspective because the examples which are important to his point, such as West Virginia's "enforced flag-salute," $i d$. at 785 (discussing state law requiring schoolchildren to salute the flag and profess loyalty to the country), arise from situations in which individuals hotly contest the 
In his discussion of sodomy laws, Rubenfeld eschews any attempt at "condemning [sodomy laws] because they merely result in persons doing the proscribed thing under the conditions of illicitness." analyses of social practices that exist "under the conditions of illicitness," his approach directs the legal inquiry towards an exclusive consideration of what happens to lesbian and gay people who comply with the law's prescription for exclusively heterosexual behavior. His project, therefore, offers a reformulated, yet limited, concept of law. ${ }^{68}$ Under Rubenfeld's framework, one is supposed to ignore the fact that sodomy laws are not actually enforced and, instead, inquire into the consequences that would hypothetically result if the laws were enforced and followed. ${ }^{69}$

Rubenfeld's model depends on the primciple that formal enforcement matters most. ${ }^{70}$ As a consequence, it proves inadequate in the context of

state's enforcement of the policy or law. Id. at 782; see also id. at 782, 784 (stating that anti-abortion laws result in "enforced identity" of motherhood, and the denial of interest of "the pregnant woman seeking an abortion"); id. at $801 \mathrm{n.223} \mathrm{("As} \mathrm{to} \mathrm{adultery,} \mathrm{the} \mathrm{case} \mathrm{is} \mathrm{much} \mathrm{less} \mathrm{clear.} \mathrm{In} \mathrm{the} \mathrm{absence} \mathrm{of} \mathrm{an}$ enforced law proscribing sex between unmarried persons, a state that barred adultery would not be standardizing its citizens into the single mold of monogamous marriage."); id. at 791 (stating that "the ban on contraception was equivalent in its positive aspect to enforced child-bearing"); id. at 795 (arguing that anti-totalitarian analysis takes cognizance that denial of the right-to-die means that "the most elemental acts of existence--such as breathing, digesting, and circulating blood-are forced upon [the terminally ill patient] by an external agency"); id. at 788 (discussing "state-enforced rule[s]"); id. at 792-93 (describing "laws against abortion, interracial marriage, non-nuclear family residences, and private education ... in ... the life of the person forced to obey"). Arguably, Rubenfeld could steer away from one aspect of "the enforcement principle" by basing the link between law and compliance on law's symbolic or constitutive effects rather than formal enforcement. This, however, is not the line he pursues, and taking such an approach would possibly introduce antinomies into aspects of his reasoning.

67. Id. at 800 n.221.

68. Rubenfeld's concept of law, in part, reflects Austinian positivism which, as characterized by Ronald Dworkin, defines a legal "command as an expression of desire that others behave in a particular way, backed by the power and will to enforce that expression ...." Ronald M. Dworkin, The Model of Rules, 35 U. CHI. L. Rev. 14, 18 (1967). In this regard, Rubenfeld's position includes a conservative element; the argument asks the law to reckon only with the consequence of people obeying its specific mandates. Moreover, the positivist tradition relies on the "will to enforce" for defining what is "real" or viable law; and Rubenfeld follows suit by pushing the question of whether a will to enforce and constitutionally validate specific legal mandates actually exists. Under this framework, because the state does not exhibit the "will to enforce" sodomy laws through its police powers, one is encouraged to believe that sodomy laws are not "real law." This narrow appreciation of the nature and consequence of law resembles the assumptions that propelled Justice Powell's view that sodomy laws were "moribund," Bowers, 478 U.S. 186, 198 n.2 (1986), as well as Dripps's conclusion that Bowers was not "a real case." Dripps, supra note 57 , at $1436,1437$.

69. See, e.g., Rubenfeld, supra note 63, at 801 ("We ought, however, to give up the image of "the homosexual' in the first place and measure the law instead in terms of its creation of heterosexuals (and, in a different way, of homosexuals too) within the standardized parameters of a state-regulated identity."); id. at 802 ("Laws that force such undertakings on individuals may properly be called 'totalitarian'....").

70. Although Rubenfeld seemingly shares Justice Powell's view of the "moribund character" of sodomy laws, he also insists that a judge should conceptualize these laws as a commitment of the law to the production of a fabricated identity for homosexual people, that is, forcing homosexuals into the role of exclusive heterosexuality. As such, Rubenfeld concedes that sodomy laws do not materialize 
sodomy statutes. ${ }^{11}$ It is common knowledge that sodomy laws do not, in actuality, "work." Focusing on sodomy laws' hypothetical enforcement, therefore, fails to evoke a sense of the laws' importance or relevance. Moreover, Rubenfeld's analytic framework perpetuates the prevailing approach to deciding the effects of sodomy statutes by considering the matter primarily in terms of compliance, arrests, and convictions.

In sum, Rubenfeld's concentration on the juridical endpoints of sodomy statutes misses wider areas of concern. Admittedly, his project makes an important contribution by arguing that the relevant inquiry should focus on social practices produced by legal sanctions rather than the social practices or behaviors those laws are meant to prohibit. Yet his model still depends on a legal regime in which formal enforcement is effective. As such, Rubenfeld's approach fails to assist in the analysis of laws whose enforcement is practically nonexistent. His analysis also encourages complacency with regard to eliminating sodomy laws because the terms of reference fail to comprehend the full and actual impact of the laws, whether enforced or not. Ultimately, the application of Rubenfeld's conceptual model to sodomy laws involves the same problem as Richard Mohr's largely theoretical and dignitarian approach. That is, Rubenfeld's model, in the context of sodomy laws, may be criticized for its excessive, if not exclusive, attachment to theoretical injuries. ${ }^{72}$

Other scholarship has taken a broader account of the sociocultural effects of sodomy laws, though still to a limited degree. The work of Kendall Thomas provides one of the most compelling responses to the narrowly conceived discussion of sodomy laws. ${ }^{73}$ In his landmark piece,

through actual force. Instead, he maintains that their legal force should still be considered on a theoretical level by asking, for example, what if the law did compel people to follow its mandate?

71. Rubenfeld's article makes exceptionally important contributions to constitutional theory and analyses of state power, and it is only in the area of anti-gay laws that 1 am arguing his analysis falls short.

72. Rubenfeld's privacy argument is more compelling when applied to other areas such as abortion. In the abortion context, his argument does have practical consequences, because under such laws, many pregnant women are legally compelled to bear children and take on the role of motherhood. Rubenfeld's argument works for the case of euthanasia as well, because terminally ill patients are forced by the state to remain alive. In the case of sodomy laws, however, his argument operates only on a conceptual level. Rubenfeld brackets crucial sociological perspectives on the law and, instead, makes a plea which rests on the emotive force of only abstract theoretical principles. (Hence, Kendall Thomas's progression on the debate in his article, Beyond the Privacy Principle. See supra note 64.) Rubenfeld's model, when applied to sodomy statutes, relies on and encourages a narrow appreciation of the real and broader effects of the law in lesbian and gay peoples' lives. This approach misses sociological insights that can perhaps only be accessed through empirical research. As Susan Silbey and Egon Bittner write: "We think that definitions of the law that take into account solely that meaning that is expressed in patterns of intended use... fall far short of acceptable standards of empirical inquiry." Susan S. Silbey \& Egon Bittner, The Availability of Law. LAw \& PoL'Y Q., Oct. 1982, at 399, 426.

73. Thomas, supra note 64; see Kendall Thomas, Corpus Juris (Hetero)Sexualis: Doctrine, Discourse, and Desire in Bowers v. Hardwick, 1 GLQ: J. OF LESBIAN \& GAY STud. 33 (1993). 
Beyond the Privacy Principle, Thomas resituates the discussion away from analyzing sodomy laws according to the administration of the state's enforcement apparatus towards studying locally diffuse and variegated power. ${ }^{74} \mathrm{He}$ submits that sodomy laws have an effect outside of traditional understandings of the law, because citizens feel empowered by the background of these laws to commit acts of extreme violence against individuals who are, or are presumed to be, lesbian or gay. ${ }^{75}$

Though Thomas breaks new ground in searching out ways in which state authority is exercised through sodomy laws, his argument deals exclusively with concepts of enforcement. ${ }^{76}$ Thomas takes as his starting point Justice Powell's discussion of enforcement in Bowers. ${ }^{77}$ Couched in terms of the legal prohibition of cruel and unusual punishment, Thomas's discussion is restricted to questions within the domain of enforcement and criminal penalty principles. ${ }^{78}$ First, he argues that public officials, such as police officers, are directly involved in anti-gay violence. ${ }^{79}$ Second, he argues that private individuals feel empowered to carry out similar forms of "enforcement." the unlawful use of state power as a tool of law enforcement."11 Thomas's framework of analysis is principally a move from considering direct state enforcement to an examination of privatized, state-sponsored enforcement. He redirects the discussion of sodomy laws to other means of punishment, but he does not move the line of inquiry away from the concern with enforcement matters. ${ }^{82}$

74. Thomas, supra note 64 .

75. Id. at 1461,1477 . Thomas uses statistical and qualitative research on anti-gay hate crimes and reviews court cases that show the law's direct support of murderers and batterers of lesbian and gay people.

76. Id. at 1487 (explaining that, at its foundation, his constitutional analysis is about "bar[ring] a state from effecting the enforcement of these laws by instigating, encouraging, or permitting" homophobic violence and describing analysis as measuring "methods that government employs to enforce its commands").

77. Id. at 1470-71.

78. The project, in the terms Thomas sets out, is "a functional, rather than formal interpretation of the prohibition against the infliction of cruel and unusual punishments." Id. at 1486.

79. Id. at 1464 ("Governmental involvement ranges from active instigation to acquiescent indifierence."); see also id. at 1465-66, 1477.

80. Id. at $1485-86$ ("In other words, private homophobic violence punishes what homosexual sodomy statutes prohibit.").

81. Id. at 1477.

82. Most notably, Thomas's focus on anti-gay violence does not address more pervasive and everyday expressions of the force of sodomy laws. Due to his enforcement-focus, Thomas investigates only the most dramatic and exceptional instances in which lesbian and gay people encounter this aspect of the law. The processes by which sodomy laws constitute social relations and affect routine behaviors and gestures is outside the scope of his project. 


\section{Opposition to the Enforcement Principle}

The foregoing has shown that the enforcement principle broadly influences legal thinking about sodomy laws. Some scholars, however, have argued against this prevailing convention by highlighting the material injustices that sodomy laws produce, whether or not the laws are enforced. This section analyzes the work of Professors Janet Halley ${ }^{83}$ and Christopher Leslie, ${ }^{84}$ who illustrate the important limitations of the enforcement principle. ${ }^{85}$ In discussing these works, it may seem as if I am identifying deficiencies. For the most part, however, my discussion is not intended to be a criticism of "failings." I am primarily explaining efforts the projects did not undertake, or conceptual frameworks they did not adopt, due to the particular scope of issues they were addressing. In so doing, I identify lacunae this Article seeks to redress.

Halley's work implicitly repudiates the enforcement principle. She argues that the maintenance of sodomy laws and debates about their retention, modification, and repeal shape the social understanding of sexual identity, and the attendant discourse yields material consequences such as stigma and the homosexual closet. She emphasizes that such consequences are not purely symbolic, but define and injure:

This particular effect of public conflict over sexual-orientation issues cannot adequately be described if we assume that the cultural effects of legal practices are "merely" symbolic. The role of the law in constituting persons by providing a forum for their conflicts over who they shall be understood to be is deeply material, even though it involves not physical force but the more subtle dynamics of representation. ${ }^{86}$

Unlike Halley, Leslie directly challenges the notion that because sodomy laws are not enforced, they do not cause material harm. He argues that these laws have three direct impacts: damage to the psychological

83. Janet E. Halley, Reasoning About Sodomy: Act and Identity in and after Bowers v. Hardwick, 79 VA. L. Rev. 1721 (1993) [hereinafter Halley, Reasoning About Sodomy]; Janet E. Halley, The Politics of the Closet: Towards Equal Protection for Gay, Lesbian, and Bisexual Identity, 36 UCLA L. Rev. 915 (1989) [hereinafter Halley, Politics of the Closet].

84. Christopher R. Leslie, Creating Criminals: The Injuries Inflicted by "Unenforced" Sodomy Laws, 35 HaRv. C.R.-C.L. L. Rev. 103 (2000).

85. For an analysis of impacts of unenforced sodomy laws in the criminal justice system, see William J. Stuntz, The Uneasy Relationship Between Criminal Procedure and Criminal Justice, 107 YALE L.J. 1, 7 (1997) [hereinafter Stuntz, Uneasy Realtionship] (describing use of unenforced sodomy statutes by prosecutors to induce guilty pleas for lesser-included offenses in charges such as sexual assault); William J. Stuntz, Substance, Process, and the Civil-Criminal Line, 7 J. ConTEMP. LegaL Issues 1, 35-36 (1996); but cf. William J. Stuntz, Self-Incrimination and Excuse, 88 Colum. L. Rev. 1227, 1288 n.220 (1988) (discounting implicitly other social impacts of sodomy laws in stating "offenses like adultery and sodomy, which remain nominal crimes in many places but which have been legalized in all but name").

86. Halley, Reasoning About Sodomy, supra note 83, at 1729. 
well-being of lesbians and gays, encouragement of anti-gay violence, ${ }^{87}$ and facilitation of police harassment. ${ }^{88}$ Neither Halley nor Leslie engage scholarship outside of the sodomy law, or the law and sexuality literatures, and therefore they do not directly engage the social norms debate. Their claims concerning the material mjuries caused by sodomy laws, however, are relevant to the discussion of law's direct, micro-level effects in individuals' lives and, in Halley's case, the sociopolitical practices which flow from that intrusion.

The current literature, Halley's and Leslie's work included, contains a significant gap in that no research has empirically measured the impact of sodomy laws on individuals' lives. Neither Halley's nor Leslie's work involves field research. ${ }^{89}$ Nor has anyone else conducted such research on the subject. The absence of such documentation constrains the persuasive force of their analysis. In fact, insofar as these authors rely on court briefs, judicial opinions, and newspaper reports to argue that sodomy laws matter, they risk creating the impression that they are only identifying the unusual occurrence or special case. Empirical work such as field research may be the best, if not the only, way to prove and present a compelling argument that overcomes those problems..$^{90}$ Field research also offers possibilities for brimging unique information to bear that is available only through ethnographic documentation. ${ }^{91}$

Indeed, some of this Article's empirical findings strongly support Halley's and Leslie's assessment that sodomy laws both diminish the selfesteem of many lesbians and gays and encourage anti-gay violence. For some individuals, however, instead of diminishing self-esteem, sodomy laws build inner strength or harden their sense of nonconformity and resistance to legal and social dictates. Such effects should be considered in an effort to appreciate the material effects of unenforced sodomy laws. The

87. Halley makes a similar claim regarding anti-gay violence. See id. at 1729-30.

88. A significant part of Leslie's article discusses indirect effects sodomy laws have had on justifying status-based discrimination by governmental and private organizations. For example, courts deny custody to lesbian and gay parents due to their quasi-criminal status, and employers fire or do not hire lesbian and gay workers on the ground of likely criminal activity. See Leslie, supra note 84, at 135-78. Those issues are beyond the scope of this Article.

89. Halley's data, for example, include court opinions, amicus briefs, records from legislative hearings, and newspaper reports. Leslie's is also a research project that includes the same types of texts.

90. Halley curiously suggests: "This rhetorical deployment of the material has grave effects on who plays in the ensuing phases of the debate. These effects are measurable not by empirical means, but by the tools offered by cultural criticism." Halley, Reasoning About Sodomy, supra note 83, at 1730. The effects on "who plays in the ensuing phases of the debate," however, are fairly easily measurable by empirical methods as well. For example, the impact on people's lives, how they orient their behavior, whether they appropriate negative sanctions: all these and more are measurable through empirical mcans such as ethnographic field research and perhaps even statistical studies using appropriate indices.

91. In Part II, I discuss, in more detail, the unique advantages of empirical research and what sociologists call "grounded theory." See infra discussion at notes 115-I16 and text accompanying notes 128-129. 
underlying social realities that produce different results should also be assessed according to intersections with structural inequalities, such as the likelihood that lesbians and gays of different classes or racial groups will resist internalizing the law's message or will minimize the impact of the law's material intrusion.

Empirical research may also productively limit the types of claims or assumptions that authors are willing to make. Halley and Leslie, for example, make statements which suggest they rely in part on an intentionalist assumption about the purpose and impact of sodomy laws, despite a lack of empirical data to support that position. Leslie contends, for instance, that "[s]tates maintain sodomy laws to pin a badge of criminality on every gay man and lesbian... states use sodomy laws to create a criminal class composed of homosexuals," men and lesbians as criminals. Social ordering necessitates the criminalization of sodomy . . .."93 Similarly, Halley writes:

Legal deterrence of homosexuality ... does all it can to motivate people to change their public self-presentations, fostering a pervasive and unquantifiable regime of mutability. Moreover, because control over the meaning of public identity is kept firmly in the hands of the antihomosexual majority, that majority retains the power to dictate still more changes. ${ }^{94}$

Empirical research casts significant doubt on the theoretical assumptions that underlie these claims. The data suggest that the consequences of sodomy laws far exceed purposeful motivation, producing unforeseen, unseen, and dysfunctional results. Many of the effects are subtle and hidden from the awareness of members of the public, including supporters of sodomy statutes and sometimes even lesbians and gays themselves. The laws, for example, place lesbians and gays outside the regular protections of law enforcement in matters unrelated to sexuality and also fracture local neighborhood and community structures. ${ }^{95}$ Indeed, the law's effects manipulate and injure people's lives in ways that many of those who support the law for strictly symbolic purposes would likely not have wanted or even imagined. Additionally, as elaborated in Part III, members of the public, including those who fully support lesbian and gay rights, are actually involved in the law's surveillance in a manner which does not support an intentionalist or functionalist perspective.

Furthermore, as discussed in Part IV, sodomy laws have played a significant role in strengthening anti-gay ideologies in other institutions of cultural authority such as religion and medical discourse, which in turn

92. Leslie, supra note 84 , at 110.

93. Id. at 112 .

94. Halley, Politics of the Closet, supra note 83, at 958.

95. See infra text accompanying notes $231-255,290-308$. 
bolster the political support for sodomy laws. Hence, a straightforward intentionalist model of sodomy laws that assumes the effect of these laws is an expression of public sentiment (without recognizing that the laws, in fact, also help to generate that sentiment) obscures the complexity of law's dynamic relationship with society and systems of social control.

At a conceptual level, Halley provides a robust analysis of the relationship between law and the production of knowledge about sexual identity through modes of social discourse. Her work, however, was not meant to, and does not in fact, provide a conceptual framework for understanding either the micro-level ways in which law affects public space or the particular sociocultural imstitutions that transmit and bolster law's message. Leslie, in contrast, provides no conceptual framework to understand the relationship between law, social control, and social interactions. I hope to supplement their work $\mathrm{m}$ this regard. The conceptual model that I develop-analyzing law's implication, at a micro-sociological level, in social surveillance of public spaces and, at a macro-sociological level, in effecting other sociocultural institutions-supports some of Halley's and Leslie's conclusions by describing the underlying dynamics that produce the results they identify. ${ }^{96}$

Finally, at different points in their analyses, Halley and Leslie both attempt to demonstrate that sodomy laws matter by suggesting that sodomy laws are enforced at a significant level. I believe these suggestions are both misleading and counterproductive in their effort to contradict the enforcement principle. At one point, Halley states that "[s]odomy statutes are materially important for concrete, material reasons: under their authority, people are in jail. ${ }^{997}$ For his part, Leslie argues, im many respects

96. In Part IV, I suggest how the macro-level analysis of other social institutions that operate alongside the law, but also in significant part because of it, may assist not only Halley's and Leslie's work but other scholarly studies of law's influence on sexuality matters as well. Notably, Leslie states:

[S]odomy laws are obviously not the sole cause of homophobia. Homophobia is far too complex a phenomenon to have a singnlar explanation. Gay people are stigmatized by several sources, including religion, social mores, and, as this Article argnes, the law. Eliminating one cause of stigmatization among many may not be a panacea but would be a step in the right direction.

Leslie, supra note 84, at 105 . However, his view of these other macro-level influences and law's possible interactions with them does not go beyond that statement.

97. Halley, Reasoning About Sodomy, supra note 83, at 1731 \& $\mathrm{n} .29$ (citing convictions in Virginia). There is good reason to believe the convictions Halley cites are guilty pleas for lesserincluded offenses of charges involving sexual assault or convictions for public sex. See, e.g., Stuntz, Uneasy Relationship, supra note 85, at 58 ("Criminal sodomy laws, where they remain on the books, serve as useful devices for extracting guilty pleas in sexual assault cases.”); Sylvia A. Law, Homosexuality and the Social Meaning of Gender, 1988 WIS. L. REv. 187, 189 ("Where heterosexual sodomy is a crime, it is apt to be prosecuted as a lesser included charge against a man accused of rape or aggravated assault."); Mitchell Lloyd Pearl, Note, Chipping Away at Bowers v. Hardwick: Making the Best of an Unfortunate Decision, 63 N.Y.U. L. REV. 154, 156-57 (1988) ("Though sodomy statutes are rarely used-at present-against consenting heterosexual adults, they are often used against persons charged with sexual assault or abuse when there is doubt on the issue of consent. Some prosecutors consider sodomy charges a useful tool in plea bargaining such cases."); id. at $157 \mathrm{n} .15$ ("[B]ecause 
accurately, ${ }^{98}$ that sodomy laws facilitate police harassment of lesbians and gays. His discussion, however, involves significant slippage between historical episodes involving actual police enforcement of sodomy laws and contemporary police practices of nonenforcement. ${ }^{99}$

Both of these discussions risk creating the mistaken impression that the argument that sodomy laws matter hinges on the premise that the laws are often or regularly enforced. In particular, Halley's citation to people incarcerated, ${ }^{100}$ and Leslie's conflation of historical and contemporary police practices, ${ }^{101}$ cast unnecessary doubt on whether the damage to lesbians' and gays' psychological well-being, and other associated harms of sodomy laws, are influenced by the "knowledge" that the laws are enforced. Certainly, if sodomy laws were enforced, these other harms would be substantially worse. Nevertheless, as my empirical research suggests, even in a climate of nonenforcement, considerable harm still results. Admittedly, the knowledge of police enforcement in the past may contribute to individuals' present-day sense of vulnerability, but it is important to separate the past events and the social consequences at that time from the contemporary period of nonenforcement and contemporary consequences. This Article's analysis of sodomy laws' impact focuses ouly on the period in which the laws have not been enforced. Past events are relevant only insofar as they inform individuals' current sensibilities.

lt is important to note that Leslie develops one other argument that unnecessarily limits the scope of his challenge to the enforcement principle, and in a sense, implicitly relies on it. In his discussion of anti-gay violence, Leslie reproduces a mistake made by Kendall Thomas. ${ }^{102} \mathrm{He}$ focuses on violent attacks by gay-bashers as though this constitutes the "privatized" mechanism of sodomy laws' enforcement. He writes: "[S]odomy

most defendants plead guilty to sodomy as a lesser charge rather than face charges for rape or aggravated sodomy (which includes an element of force), there is little recent appellate law on the subject.") (citation omitted). Cf. William N. Eskridge, Jr., Gaylaw: Challenging the Apartheid OF THE CLOSET 375 (1999) (documenting exceptionally small number of same-sex consensual sodomy cases from 1880 to 1995$)$.

98. Aspects of Leslie's assessments in this regard are supported, and extended further, by the empirical findings in Part III. For example, episodes in which police officers use the threat of sodomy laws to blackmail gay men or con artists pose as police officers to extort money from unsuspecting gay men. See infra text accompanying notes 283-284.

99. See, e.g., Leslie, supra note 84 , at $130 \&$ n.I77 (stating "police routinely stake out and operate undercover in gay bars and pick-up places in order to find gay men willing to engage in oral sex"). Leslie cites William N. Eskridge, Jr., Challenging the Apartheid of the Closet: Establishing Conditions for Lesbian and Gay Intimacy, Nomos, and Citizenship, I961-1981, 25 HofsTrA L. REv. 817,860 (1997), which discusses police practices in the 1960s and 1970s; see also Leslie, supra note 84, at 130-32 \& n.193 (relying on support from Jon J. Gallo et al., The Consenting Adult Homosexual and the Law: An Empirical Study of Enforcement and Administration in Los Angeles County, I3 UCLA L. REv. 643 (1966)).

100. See Halley, Reasoning About Sodomy, supra note 83, at I731 \& n.29.

101. See Leslie, supra note 84 , at 127-35.

102. See supra text accompanying notes 76-82 (discussing similar aspect in Thomas's work). 
laws make gay individuals targets for physical violence in the form of gay bashing, sometimes perpetrated as de facto enforcement of sodomy laws." 103 Leslie also explicitly relies on Thomas for the proposition that "sodomy laws represent 'constructive delegation of governmental power' to those citizens who use violence against gay men and lesbians as a means of enforcing those laws." 104 Overemphasis on these extraordinary moments of violent intrusion, as if such violence is the law's primary mechanism for control and the public's principal form of involvement, however, is a dangerous mismeasure of the interplay between law and society and the general public's role. Leslie and Thomas's depiction does not explain the daily and routine ways in which the public at large is involved in disciplining and regulating lesbian and gay people's lives, the ways in which even neighbors and family are also empowered by the laws, and the lawv' implications in other routine social interactions.

Despite the limitations 1 have identified in these authors' works, as well as those in the previous section, ${ }^{105}$ I share the purpose and commitment animating their endeavors. These scholars should be credited with having made the first steps toward moving the terms of the discussion beyond conventional considerations of law and social order. Their work points in the direction of an analytic path that this Article will take up and widen.

Turning from the specific literature on sodomy laws, the balance of the Article addresses the micro- and macro-social effects of sodoiny laws specifically and the implications this study has for ongoing academic discussions in the field of social norms scholarship more generally. Immediately below, in Part II, 1 explain my theoretical and methodological approach, and then the historical background that informs the study.

Il

\section{Methodological, Theoretical, and Historical Foundations}

Although social norms scholarship has begun borrowing extensively from sociology, commentators have observed that "[w] hat is still missing is a discussion of the theory underlying that sociology." 106 Part II both describes the sociological theory that guides this project and the reasons for the inethodological approach adopted.

103. Leslie, supra note 84 , at 104 . Leslie states "sometimes," because some gay bashers are prone to attack lesbians and gays not with the mens rea of enforcing law's dictates, but simply because lesbians and gays are more vulnerable.

104. Id. at 124 \& n.137 (citing Thomas, supra note 64, at 1481-82).

105. See supra Part 1.B (analyzing the work of Jed Rubenfeld and Kendall Thomas).

106. Harcourt, supra note 10 , at 300 ("One of the great contributions of social norm proponents has been to integrate sociology into the public policy discussion of crime. What is still missing is a discussion of the tbeory underlying that sociology."); see also Jeffrey J. Rachlinski, The Limits of Social Norms, 74 CHI.-KENT L. REV. 1537 (2000); Etzioni, supra note 7, at 157. 


\section{A. Towards a Constitutive and Empirical Analysis}

This Article's method for studying sodomy laws borrows from an emergent body of work in sociolegal studies known as constitutive theories of law. ${ }^{107}$ I explore the relationship between law and everyday life, or rather between law on the books and law in action. Other scholarship on sodomy laws may do some of the same. The distinction between this study of sodomy laws "in action" and previous academic work is the methodological emphasis on inquiring (1) beyond formal institutions of state power and (2) beyond the extraordinary times in which law directly intervenes in people's lives. The present project accordingly tracks the constitutive effects of law; that is, the ways in which sodomy laws operate in daily life by shaping interpersonal relations, influencing daily habits, and helping define civic identity. ${ }^{108}$ Because many of these effects occur along a dimension that is subtle or subconscious, it is important to remain aware of the instrumental effects of law, including individuals' conscious efforts to subvert, confront, or follow law's dictates. Our examination of law's influences on social behavior should therefore try to account for these multiple effects of law as well.

In some respects, this project, and the works discussed above, share a common sociological perspective. Whether acknowledged or not, those scholars and jurists who adhere to the enforcement principle are engaged in what has become a mainstay of sociolegal studies: analyzing "the gap" that exists between legal rules and their actual enforcement. ${ }^{109}$ The field of law and society scholarship has long foregrounded "the gap problem," and

107. See, e.g., Alan Hunt, Explorations in Law and Society: Toward a Constitutive THEORY OF LAW 303 (1993) ("Law is to be understood not in itself, through the intersection of self-referentiality, but rather from addressing the connectedness of law, from viewing law in its location interacting with and interpenetrating other social processes.").

108. Robert Gordon persuasively argues for the benefits of examining law's force in daily, local, social interactions rather than concentrating on "a bunch of discrete events that occur within certain specialized state agencies ...." See Robert W. Gordon, Critical Legal Histories, 36 StaN. L. Rev. 57, 107 (1984). Gordon explains that the more restrictive view tends to

assume that the only question for a social history of law is the relation between the output of these agencies and social change. But if that output is all there is to law, how on earth are we going to characterize all the innumerable rights, duties, privileges and immunities that people commonly recognize and enforce without officials anywhere nearby?

Id. The present project is an attempt to study the quotidian life of the law. Gordon's discussion concerns the social reality produced by law as those rules more directly constitute individuals' selfidentity and interactions (such as landlords and tenants). My study adopts a broader definition of law's constitutive effects. I examine not only law's role in the formation and boundary-setting of a specific category of people, but also the patterns of behavior and individuals' expectations consciously and subconsciously influenced by law's sanction as a background matter.

109. For a discussion of sociology's role in the interdisciplinary movement that gave rise to "gap studies," see Alan Hunt, The Sociological Movement in Law (1978). For a discussion of anthroplogy's role in "gap studies," see Annelise Riles, Representing In-Between: Law, Anthropology, and the Rhetoric of Interdisciplinarity, 1994 U. ILL. L. REV. 597, 633 ("For many writers, law is partial or incomplete in one very particular way: A gap separates law from the real world and anthropology, as the study of real societies, stands to close that gap by relating law to society."). 
an influential result of that sociological perspective has been to focus legal inquiries on questions of whether (as well as how and why) legal rules lack application in practice. ${ }^{110}$ Insofar as they call attention to the enforcement problein, discussions about sodomy laws may be said to share in this sociological tradition.

Within sociolegal studies, however, this fairly narrow framework of analysis has been the subject of growing dissatisfaction. An emergent body of scholarship has recognized conceptual limitations of "gap studies" and has turned instead towards constitutive theories of law. ${ }^{111}$ In his analysis of these developments, Robert Gordon identifies the most likely reasons for law and society scholars' failure to take account of the constitutive effects of law. In a landmark piece, Critical Legal Histories, Gordon explains that scholars who were involved in the law and society movement were principally focused on effectuating progressive legal reform. ${ }^{12}$ Disillusioned by the failures of formal implementation, these scholars neglected the opportunity to refocus their efforts on the more subtle ways in which law produces and regulates social relations. ${ }^{113}$ John Brigham, one of the leading figures in constitutive legal studies, explains his dissatisfaction with law and society scholarship more generally:

Professor Harrington and I began a book series with the intention of developing a platform for constitutive work. We said we were focusing "on the law $\mathbb{I N}$ society, shifting attention away from the postwar framework which conceptualized law outside of society only to discover its political character." We wanted to "go beyond the truism that law is political and begin to examine the ways in which law constitutes social relations." We wanted to "challenge

110. For example, Stewart Macaulay starts his seminal article by asking: "What good is contract law? who uses it? when and how?" Stewart Macaulay, Non-Contractual Relations in Business: $A$ Preliminary Study, 28 AM. Soc. Rev, 55, 55 (1963). Macaulay's study of the relative insignificance of legal nules in actual practice shares a common purpose or sensibility with commentators such as Dripps and Posner discussed above. This area of "gap studies" concerns the inconsequential nature of law in various social practices. See also RoBERT Ellickson, ORder Without LAw: How Neighbors SETTLE Disputes (1991). In this sense, although I share the sociological commitment to study the difference between law on the books and law on the streets, my purposes and the conclusions I draw are quite different.

111. Rosemary J. Coombe, The Cultural Life of Things: Anthropological Approaches to Law and Society in Conditions of Globalization, 10 AM. U. J. INT'L L. \& PoL'Y 791, 793 (1995) ("Constitutive theories of law recognize law's productive power, as well as its prohibitory and sanctioning functions-shifting our attentions to the working of law in ever more improbable settings. Focusing less exclusively upon formal institutions, law and society scholarship has begun to look more closely at law in everyday life, in quotidian practices of struggle, and in consciousness itself.").

112. See Gordon, supra note 108, at 108; see also Bryant G. Garth \& Austin Sarat, Justice and Power in Law and Society Research: On the Contested Careers of Core Concepts, in JusTICE AND Power IN Sociolegal Studies 1, 4 (Bryant Garth \& Austin Sarat eds., 1998).

113. See Gordon, supra note 108, at 108 (explaining, in detail, the loss of sociological perspective within the movement). 
the conventional idea that law simply referees contests of interest."114

I agree with Brigham that a critical shift in perspective entailed by the constitutive project is the methodological turn away from studying "law and society" towards studying "law in society." Whereas the former investigates the political character of law, the latter investigates the field of local social relations and everyday life in which law has a constitutive effect. The constitutive approach involves a methodological emphasis on empirical research to illuminate the ways in which people, as a matter of practice, understand and relate to legal rules. ${ }^{115}$ By privileging "research first," these projects brimg new data to the analytic table, thus enabling the remodeling of existing theories of law and social relations. ${ }^{116}$

Many works in constitutive sociolegal scholarship combine (1) a commitment to empirically based research with (2) a conceptual understanding of power relations influenced by the work of Michel Foucault. ${ }^{117}$

114. John Brigham, The Constitution of Interests: Institutionalism, CLS, and New Approaches to Sociolegal Studies, 10 Yale J.L. \& Human. 421, 431 (1998) (quoting FLYER, After the Law (1990)).

115. In his discussion of the virtues of empirical research, Brigham refers back to Gordon's survey of the types of "field-level" research that can illuminate the contours of law in mundane social affairs: "[Gordon] pointed to research that found the basic elements of formal legal rules of property and contract internalized by laypeople and routinely applied in contexts remote from officials and courts. According to Gordon, 'field-level studies would reveal a lot of trickle-down effects-a lot of mandarin ideology reproduced in somewhat vulgarized forms." Brigham, supra note 114 , at 428 (quoting Gordon, supra note 108, at 121). See also Riles, supra note 109, at 635 ("A corollary to this vision of law's incompleteness is that anthropological or sociological research provides a desperately needed empirical antidote to the unsophisticated ruminations of legal academics.").

116. One of the best works in empirically based, ground-up approaches to analyzing law's constitutive effects is Patricia Ewick \& Susan S. Silbey, The Common Place of Law: Stories FROM EVERYDAY LIFE (1998). Ewick and Silbey's research methods emphasize information gathered through qualitative field research as the most effective and reliable way to ground and remodel conceptual theories of law. Projects such as these, which derive theory from data, have a close connection to a genre of sociological research known as "grounded theory." See BARNEY G. GLASER \& Anslem L. Strauss, The Discovery of Grounded Theory (1967). Much stands to be gained from sociolegal scholars adopting a more explicit discussion of the research methods that they employ. In this project, I employ a grounded theory approach to reformulating theories of how a specific set of laws work in social relations. However, I agree with others, such as Michael Burawoy and Aaron Cicourel, that a researcher engaging in grounded theory always enters the field with some theoretical presumptions and unconscious filtering devices that are necessary, for example, in sorting out socially relevant behavior patterns and social relations. Michael Burawoy, Reconstructing Social Theories, in Ethnography Unbound: Power and Resistance in the Modern Metropolis 8, 9 (1991); Aaton V. Cicourel, Field Research: The Need for Stronger Theory and More Control over the Data Base, in CONTEMPORARY ISSUES IN THEORY AND RESEARCH 61 (William E. Snizek et al. eds., 1979). Therefore, although this project is "grounded" by the fact that it generates its final theoretical conclusions from the empirical research, it also relies on existing theories (such as constitutive theories of law) to organize and understand the research and its findings.

117. See, e.g., James Gray Pope, Labor's Constitution of Freedom, 106 Yale L.J. 941, 952-53 (1997); Mary Eaton, Homosexual Unmodified: Speculations on Law's Discourse, Race, and the Construction of Sexual Identity, in Legal Inversions: Lesbians, Gay MEN, and the Polmics of LAw 46-73 (Didi Herman \& Carl Stychin eds., 1995); Mark Barenberg, Democracy and Domination in 
This Article also relies on some of Foucault's msights to help articulate and better understand significant aspects of this project's fimdings. Alan Hunt, one of the pioneers of the constitutive approach, ${ }^{118}$ has strongly advocated such an incorporation of Foucault's work into sociolegal projects. ${ }^{119}$ To do so effectively, Hunt suggests, it is also necessary to effect a "retrieval of law" into Foucault's work. ${ }^{120}$ Hunt explains that one has to choose selectively from, or modify, Foucault's analysis of power to successfully combine constitutive sociolegal studies with Foucauldian theories. ${ }^{121}$

It is doubtful how far one really has to go to retool Foucault im order to analyze the constitutive effects of law; Foucault himself would have embraced some of the more nuanced ways of describing law's production of local social relations and law's involvement in individuals' selfsurveillance. ${ }^{122}$ Nonetheless, Foucault strongly disavowed theories that assumed power was located principally in the state's repressive apparatus or, as he called it, "power-sovereignty." 123 It is therefore important to acknowledge the potentially uneasy umion of Foucault's conceptual framework, in which power is often described as dispersed, productive, and exercised through local discourses, and empirical research that einphasizes the importance of law's influence on social relations. While recognizing

the Law of Workplace Cooperation: From Bureaucratic to Flexible Production, 94 Colum. L. REv. 753 (1994).

118. See generally Hunt, supra note 107.

119. Id. at 292-94; Al.AN Hunt \& Gary WickHam, Foucault and Law: Towards a Sociology of LAW As Governance (1994); Alan Hunt, Foucault's Expulsion of Law: Toward a Retrieval, 17 Law \& Soc. INQuirY 1 (1992).

120. Hunt, supra note 119, at 38; see also id. at 30-37.

121. Foucault, in fact, encouraged other scholars to forage through his work and to take what they need:

All my books ... whether [Madness and Civilization] or this one [Discipline and Punish], are little toolboxes, if you will. If people are willing to open them and make use of such and such a sentence or idea, of one analysis or another, as they would a screwdriver or a monkey wrench, in order to short circuit or disqualify systems of power, including even possibly the ones my books come out of, well, all the better.

Didier ERIBON, Michel Foucaulr 237 (Betsy Wing trans., 1991) (quoting Michel Foucault).

122. Frank Munger also suggests that constitutive theories of law complement Foucauldian cultural analysis. Frank Munger, Sociology of Law for a Postliberal Society, 27 Loy. L.A. L. REv. 89, 103 (1993). ("Constitutive theory seems to share with Michel Foucault's description of cultural history a belief that culture determines the microdistribution of power, thus decentralizing-but also largely determining-the allocation of power in society."). Munger argues that the state receives ample attention in Foucault's analysis of power:

Much of the recent work in sociolegal studies reflects an acceptance of this vision of the decentralization of power. According to Professor Foucault, the state itself links together an overall strategy from the micropowers implicit in such techniques; thus, its own power is inseparable from the manner in which it is exercised in the many different settings over which it presides.

Id. at 120-21.

123. Michel Foucault, The History of Sexuality: Volume I: An Introduction 90 (Robert Hurley trans., Vintage Books ed. 1990) (1978). 
this tension, scholars such as Hugh Baxter, ${ }^{124}$ Susan Silbey, ${ }^{125}$ and Jonathan Simon ${ }^{126}$ have called for new research agendas that embrace Foucauldian concepts while conducting inquiries that attend to law's more nuanced sociocultural effects. This Article follows that agenda and provides further confirmation that the marriage between Foucauldian and constitutive theories of law works.

Finally, while this project emphasizes the constitutive approach, it is not intended to overlook the instrumental features of sodomy laws as a result. That is, I do not want to repeat the mistake identified by Austin Sarat and Thomas Kearns that "[i]nstrumental and constitutive approaches have largely talked past each other." ${ }^{\text {"127 }}$ As Sarat and Kearns suggest, an empirically-based study should be able to identify both the constitutive and instrumental features of law. ${ }^{128}$ Out of field research and data-gathering, an understanding of both aspects of law's involvement in the social environment should emerge. Sociolegal work simply requires attentiveness to this distinction and a commitment to discuss both dimensions of law. "Only if we can find ways to bridge the great divide between instrumental and constitutive approaches in legal scholarship can we begin to appreciate the richness and complexity of the way law makes its presence felt in everyday life."129

Informed by the emergent sub-field of constitutive sociolegal studies, but taking into account law's instrumental effects as well, 1 hope to advance a thick description ${ }^{130}$ of the way sodomy laws operate through people's lives, and to improve upon other theoretical models that analyze law's impact in society. When sodomy laws "live[] in persons," "31 power is exercised through multivalent and unequal social relations: some individuals are its social enforcers, monitors, and judges, while others are defined as the outlaw class. ${ }^{132}$ Law may lack formal enforcement in that officials fail

124. Hugh Baxter, Bringing Foucault into Law and Law into Foucault, 48 STAN. L. REV. 449 (1996) (reviewing HUNT \& WICKHAM, supra note 119).

125. Susan S. Silbey, Making a Place for Cultural Analysis of Law, 17 LAw \& Soc. INQUIRY 39, $41-48$ (1992).

126. Jonathan Simon, "In Another Kind of Wood": Michel Foucault and Sociolegal Studies, 17 LAW \& SOC. INQUIRY 49 (1992).

127. Austin Sarat \& Thomas R. Kearns, Beyond the Great Divide: Forms of Legal Scholarship and Everyday Life, in LAW IN EvERYDAY LIFE 21, 61 (Austin Sarat \& Thomas R. Keams eds., 1993).

128. Id. at 55-56.

129. Id. at 61 .

130. ClifFord GEertz, Thick Description: Toward an Interpretive Theory of Culture, in THE INTERPRETATION OF CULTURES 3 (1973).

131. John T. Noonan, JR., Persons and Masks of the Law 4 (1976).

132. Cf. Robert Weisberg, Private Violence as Moral Action: The Law as Inspiration and Example, in LAw's VIOLENCE 175, 176 (Austin Sarat \& Thomas R. Kearns eds., 1992) ("Throughout our legal history, we observe the complex ways the law rationalizes itself out of this dilemma, while nevertheless at times punishing, permitting, accommodating, encouraging, or inspiring the very private violence it purports to supprcss or replace."). 
to arrest, try, or convict law-breakers; yet the sociological force of law may be found in other personal, family, and communal relations of domination and regulation. ${ }^{133}$ On the surface, the law on the books may appear moribund. At a deeper level of inquiry, however, these laws can be seen to manipulate, confine, sentence, and punish individuals' lives. This is the social experience of sodomy laws within South Africa and within the particular lives of many lesbian and gay people.

\section{B. Framing the Discussion}

In line with this sociological approach to analyzing the effects of sodomy laws, the body of this paper depends on the voices of many lesbian and gay South Africans. Their stories were gathered through seventy-one open-ended, intensive, one-on-one interviews that I conducted in the summer of 1995 and in the spring of $1999 .{ }^{134}$ While the 1995 interviews focused on individuals' recent and ongoing experiences under South Africa's sodomy laws, the 1999 interviews focused on the changes (or lack of changes) people experienced since the laws' invalidation. In 1995 and 1999, I participated in the meetings of groups of individuals with significant experience in lesbian and gay services and outreach programs. I also conducted background interviews with some of these participants, including clinical psychologists, HIV/AIDS workers, civil and political rights activists, and attomeys. These sessions were primarily designed to gather "secondary information" concerning the historical context of the anti-gay laws, and to identify issues for exploration in the primary interviews. I also have relied on two secondary sources as supplementary material: a collection of essays in Defiant Desire: Gay and Lesbian Lives in South Africa, ${ }^{135}$ as well as Male Homosexuality in South Africa: Identity Formation,

133. Law, as understood here, thus goes beyond Max Weber's classical definition of law as an order "externally guaranteed by the probability that coercion (physical or psychological), to bring about conformity or avenge violation, will be applied by a staff of people holding themselves specially ready for that purpose." MAX WEBER, ON LAW IN Economy and Society 5 (Edward Shils \& Max Rheinstein trans., Max Rheinstein ed., 1954). Law's enforcers are not merely those who wear uniforms or work for the state. Law empowers many social actors vis-á-vis the criminalized class. Kendall Thomas's discussion of gay-bashers as "privatized" enforcers is one example of the expansive reach of the state. See Thomas, supra note 64, at 1481-82 (framing his thesis as "violence against gays and lesbians perpetrated by other citizens represents the states" constructive delegation of governmental power to these citizens" and describing this as the "functional privatization of state power that structures the triangular relationship among victim, perpetrator, and state"); see also supra text accompanying notes 71-80. This Article will also discuss other actors (including loving family members, officious neighbors, and the observing public) whose power over disfavored individuals is amplified by the background setting of the law. Bringing attention to these actors and their multivalent forms of legally-backed force reveals surreptitious yet encompassing ways in which the law is diffused through the social body and into particular individuals' lives.

134. For a more thorough discussion of methodology, see Appendix A.

135. Defiant Desire: Gay and Lesbian Lives in South Africa (Mark Gevisser \& Edwin Cameron eds., 1994) [hereinafter DEFIANT DESIRE]. 
Culture, and Crisis. ${ }^{136}$ There are no other major works on lesbian and gay life in South Africa ${ }^{137}$ aside from a few journal articles, some of which have also helped in my endeavors. ${ }^{138}$

Several factors make the South African experience especially conducive to informing the American legal discussion. Like the United States, South Africa's criminalization of sodomy originated with European colonial settlers, and in their modern incarnation the laws have remained largely unenforced. ${ }^{139}$ The legal climate that existed between 1994 and 1998 , the time in which 1 conducted the first set of field research for this project, was also particularly favorable to the study of sodomy laws. During that period, the newly minted constitution contained equal protection guarantees against sexual orientation discrimination, but sodomy laws were still kept on the books. This legal climate allowed for a unique apprehension of the impact of sodomy laws in people's lives by giving me the opportunity to study sodomy laws while suspending the alternate influence of a generally hostile, discriminatory legal system. ${ }^{140}$ The constitutional prohibition of sexual orientation discrimination together with the maintenance of prohibitions on same-sex practices also resembled features of the present American legal environment, or rather where the American legal system seems headed. ${ }^{141}$ Finally, the South African legal transformation

136. Gordon Isaacs \& Brian McKendrick, Male Homosexuality in South Africa: IDENTTtY Formation, Culture, and Crisis (1992).

137. See T. Dunbar Moodie et al., Migrancy and Male Sexuality on the South African Gold Mines, in Hidden From History: Reclaiming the Gay and Lesbian Past 411, 411 (Martin Baumel Duberman et al. eds., 1989) ("Virtually no work las appeared on the history of homosexuality anywhere in sub-Saharan Africa, let alone in South Africa ....").

138. E.g., id.; Pierre De Vos, On the Legal Construction of Gay and Lesbian Identity and South Africa's Transitional Constitution, 12 S. Afr. J. Hum. RTs. 265 (1996).

139. See infra text accompanying notes 170-174 (discussing lack of enforcement in South Africa); see also supra note 97 (discussing lack of enforcement in the United States).

140. I also believe the constitutional environment facilitated my research in that lesbian and gay people were less insecure and more willing to talk about their experiences.

141. Current American constitutional law on sexual orientation is characterized by a similar disjuncture, with both Romer v. Evans, 517 U.S. 620 (1996) (invalidating anti-gay state referendum on rational basis equal protection grounds), and Bowers v. Hardwick, 478 U.S. 186 (1986) (upholding state sodomy law on rational basis due process grounds), on the constitutional law books. The legal environment appears to be moving towards greater protection against discrimination based on sexual orientation status but retention of laws that proscribe same-sex conduct. Romer, for one, signals the prospects of heightened judicial scrutiny for sexual orientation classifications in the future. See, e.g., Tobias Barrington Wolff, Note, Principled Silence, 106 YALE L.J. 247, 250 (1996) (arguing that Romer is similar to the Court's decision in Reed v. Reed, 404 U.S. 71 (1971), "the case that ushered in the era of heightened scrutiny for gender discrimination"). Furthermore, in several court cases involving the U.S. military's exclusion policy, where deference to the government is the greatest, some federal judges have signaled a willingness to use the Equal Protection Clause to invalidate status-based discrimination, by distinguishing prohibitions on conduct (which, they demur, are justified) from prohibitions based on status (which, they argue, are not). See, e.g., Pruitt v. Cheney, 963 F.2d 1160, 1165-66 n.5 (9th Cir. 1991 ) (reasoning that Bowers "was a case relating to conduct, not orientation" and therefore did not preclude heightened equal protection review for evaluating discrimination on the basis of sexual orientation); Watkins v. United States Army, 875 F.2d 699, 716-17 (9th Cir. 1989) (en banc) (Norris, J., 
with regard to sodomy laws-the invalidation of the laws by the Constitutional Court in 1998-provided a unique opportunity for analytic work. Most importantly, the South African legal transformation provided access to the ways individuals' lives may or may not change after the abolition of such laws, thus making it easier to determine what effects these laws truly have in operation. ${ }^{142}$ This aspect of the study also allowed interviewees to discuss the ways in which they now, in the aftermath of the laws, reflect on their past experiences and the role they previously assigned to the law in their life. Given the historical similarities of sodoiny laws in South Africa and the Uirited States, and the recently amended South African constitution, the South African experience clearly offers an important occasion to assess the social realties of the criminalization of sodomy and its aftereffects.

In terms of sexual identity, my discussion is circumscribed by speciflc demographic boundaries. Specifically, the project is confined to the lives of lesbians and gays in the proximity of industrialized urban areas or relatively large cities. By setting these boundaries, this Article's discussion avoids soine potentially vexing issues that might otherwise be raised due to variances in sexual desire and sexual practices. Other scholarship on samesex sexuality in South Africa concludes that participants in same-sex sexual practices in speciflc times (for example, during apartheid) and places (for example, single-sex hostels for mineworkers) have not defined

concurring) ("[T]he class of persons involved in Hardwick-those who engage in homosexual sodomy -is not congruous with the class of persons targeted by the Army's regulations-those with a homosexual orientation. Hardwick was a 'conduct' case; [the present plaintiff's] is an 'orientation' case."); Able v. United States, 968 F. Supp. 850, 864-65 (E.D.N.Y. 1997) (applying heightened scrutiny to invalidate military exclusion policy on the ground that classification was based on sexual orientation, not sodomy, and therefore distinguishing Bowers), rev'd Able v. United States, 155 F.3d 628, 635 (2d Cir. 1998) (reversing district court but stating "Romer ... differ[s] from this case because it involved restrictions based on status. In our previous opinion, we rejected plaintiffs' argument that the [Don't Ask, Don't Tell] Act was only a status-based prohibition and held that the Act targets conduct."); Cammermeyer v. Aspin, 850 F. Supp. 910, 918 (W.D. Wash. 1994) (invalidating National Guard's discharge of lesbian by distinguishing Bowers as concerning sexual act not sexual orientation); Meinhold v. United States Dep't of Def., No. CV 92-6044 TJH (C.D. Cal. May 14, 1996) (mem.), aff'd, Meinhold v. United States Dep't of Def., 123 F.3d 1275, 1284 (9th Cir. 1997) ("The Supreme Court, in upholding the Georgia statute, held that the Constitution does not confer a fundamental right upon homosexuals to engage in sodomy. Bowers never addressed the issue of whether a person's status as a homosexual, as opposed to conduct, was constitutionally protected."). The lesbian and gay rights movement has also been focusing on status-based antidiscrimination law. This Article's argument for the importance of sodomy statutes is, as such, also a caution not to underestimate the profound importance of sodomy statutes and, as a consequence, leave these laws behind in the litigation and legislative struggle.

142. Indeed, the longitudinal dimension of this empirical work, having interviewed the same people in 1995 (under the sodomy laws) as in 1999 (after the laws' invalidation), may be the first of its kind in the study of legal regulations of homosexuality. 
themselves as "gay" or "homosexual." 143 The present Article avoids such issues by focusing its inquiry on specific temporal and demographic locations. All my interviews were conducted with people living in or around major cities in South Africa such as Cape Town, Durban, Johannesburg, and Port Elizabeth. Almost every interviewee self-identified according to familiar non-heterosexual labels: "lesbian," "gay," and "homosexual," as one might expect in the United States. ${ }^{144}$ Indeed, many of my interviewees regarded their sexual identity for all practical purposes as indistinguishable from that of their American counterparts.

In terms of sociolegal history, several meaningful correlations also exist between the South African and American past. In sexual orientation matters, the two nations share a remarkably common history with regard to statutory and common law regimes and attendant exercises of state power. Part IV explains the development of South African sodomy laws, revealing important commonalities with the American experience. Notably, the two legal systems, including their respective sodomy laws, were not only originally imported by. European settlers, but also share a similar historical lineage tracing back to Christian edicts and possibly Roman law. ${ }^{145}$ In their

143. See, e.g., Glen Elder, Of Moffies, Kaffirs and Perverts: Male Homosexuality and the Discourse of Moral Order in the Apartheid State, in MapPIng Desire: Geographies of Sexualties 56 (David Bell \& Gill Valentine eds., 1995); T. Dunbar Moodie et al., supra note 137, at 411.

144. Indeed, the lesbian and gay section of contemporary South African bookstores, libraries, and individuals' personal collections are filled almost exclusively with books by American and European authors.

145. Pierre De Vos argues for the unique experience of colonialism in shaping South African "homosexual identity":

The emergence of a discourse on homosexuality in South Africa does not follow the same historical trajectory as its European colonial antecedents. Not only is the periodisation different, but the social process also transforms the discursive character of sexual relations in a different way. The central role of missionaries in the process of colonial conquest, the rise of the colonial state as the new sovereign power on the subcontinent, and the interest of the mining houses sometimes contested but mostly colluded in a formation of institutions to regulate the distribution of discipline on the bodies of all its subjects.

De Vos, supra note 138 , at 274 . The substantive focus of my project diverges from De Vos in that I am more concerned with the management and violence of law in people's lives, not with law's role in the construction of a "homosexual" identity. In terms of my analytic inquiry, the American and South African experience may share more affinities than the sociocultural phenomena conceming the construction of homosexual identity that De Vos addresses.

Nevertheless, 1 disagree with De Vos's characterization of the uniqueness of South African lesbian and gay identity. Relative to the phenomenal diversity of same-sex sexual rituals, identities, and practices across the globe, South Africans and Americans who self-identify as lesbian, gay, and "homosexual" are virtually identical. Cf. Third Sex, Third Gender: Beyond Sexual Dimorphism IN CUlture AND History (Gilbert Herdt ed., 1994) (demonstrating through case studies the expansive range of same-sex sexual diversity across space and time). Indeed, De Vos himself relies heavily on the experience of sexual orientation law and lesbian and gay culture in the United States in his discussion of South African lives. Id. at passim. His work thus indicates a recoguition of strong affinities between contemporary homosexual identity in at least these two countries, even if the American and South African category of experience is markedly different from many other areas of the world. Finally, it is important to note that De Vos characterizes the South African experience as unique in terms of its colonial legacy. As the discussion in the following Part indicates, the American and South African 
contemporary form, the sodomy laws of both countries virtually mirrored one another in text. ${ }^{146}$

The argument that follows indicates a similar periodization of legal regulation within the two countries. ${ }^{147}$ South Africa and the United States went through almost parallel historical stages: from actual enforcement of police powers, to police harassment, to a "Stonewall awakening," to a lesbian and gays rights movement, and finally to subsequent nonenforcement. Admittedly, the background of the apartheid state entailed important differences that contrast with the American experience. The discussion in Parts III and IV identifies some of those distinctions, such as the unique impact of racial discrimination combined with sexual orientation discrimination for South Africans of color. It is worth noting, however, that for white lesbian and gay South Africans who lived in relatively liberal and privileged conditions, the force of anti-gay laws was profound. This case study therefore illuminates the impact such laws can have by revealing the damage done to individuals who possess political liberties and material resources that should otherwise help protect them. ${ }^{148}$ The experience of lesbian and gay South Africans of color is also illustrative of broader lessons in this regard. Set within a racially discriminatory state and social system, the criminal laws against homosexuality entailed significantly worse problems for lesbians and gays of color. ${ }^{149}$ These conditions accentuate what exists in other industrialized countries; that is, the South African case study makes it easier to discern social dynamics that occur, though to a different degree, in other racially divided political and social systems.

experience share much in common both in terms of European colonial law and sodomy laws in particular.

146. See infra text accompanying notes 163-164.

147. Aspects of the South African social history with anti-gay laws and police harassment also surely vary from the American experience. One might, therefore, reason that some of the South African lesbian and gay individuals' responses to sodomy laws were based in part on these different social conditions. In certain respects, such variances in social contexts do reduce the potential for sharing comparative insights between the two countries. Interestingly though in this project, these constraints on drawing comparative lessons also have a significant benefit: they strongly suggest to scholars fixated on the enforcement principle that social context seriousiy matters. One cannot determine sodomy laws' impact based on their lack of enforcement without investigating the social context and effects. Additionally, in terms of social norms theory, these differences demonstrate the need for integrating a robust understanding of other social forces when examining a law's potential impact, in order to capture the true nature of the law's expressive and instrumental effects. In a country as vast and demographically diverse as the United States, it might call for different analyses of the same law in different geographic locations (such as the Deep South versus the Northeast).

148. See, e.g., infra text accompanying notes $227,255-256$.

149. See, e.g., infra text accompanying notes $253-255,286-290$. 


\section{A Brief History of South African Sodomy Laws}

\section{The Early Years: The Origin of Sodomy Laws in South Africa}

The criminalization of sodomy in South Africa predates the formal establishment of apartheid by more than two hundred years. In the seventeenth century, Dutch colonizers introduced the Roman Dutch common law as part of the new legal system in southern Africa. ${ }^{150}$ Under this legal regime, acts of "sodomy" were considered a crimmal offense. ${ }^{151}$ The definitional scope of the offense, however, only loosely resembled its modern incarnation. The crime of sodomy comprised a catalog of "unnatural offenses," which included a range of nonprocreative sexual practices such as sexual acts between men, sexual acts between women, bestiality, malefemale anal intercourse, and masturbation. ${ }^{152}$

150. The Dutch East India Company had set up a "refreshment station" at the Cape of Good Hope in 1652 and from there "[t]he South African legal system had its humble beginnings." Frank Berman, South Africa: A Study of Apartheid Law and Its Enforcement, 2 Touro J. TRANSNAT'L L. 1, 3 (1991). For a leading account of South African history from colonial beginnings to the start of the postapartheid transition, see Allister Sparks, The Mind of South Africa (1990).

151. De Vos, supra note 138, at 274; see also Arend H. Huussen, Jr., Sodomy in the Dutch Republic During the Eighteenth Century, in HIDDEN FROM HISTORY: RECLAIMING THE GAY AND LESBIAN PAST, supra note 137, at 141, 142. In the Dutch homeland, courts had been sentencing people to death for the crime of sodomy since the 1530s. Id. at 144-45 (documenting both pre-1730 sporadic cases of sodomy sentences evident in trial records and subsequent waves of persecution in 1700s). The Dutch occupied the Cape until 1795, so it is reasonable to suspect that the eighteenth century panic over sodoiny and the ensuing persecutions back home influenced the makeup of the common law of the Cape colony. Id. at 143-44 (accounting for panic by Calvinist ministers and members of the judiciary in Dutch Republic); $c f$. Lourens M. Du Plessis, An InTroduction to LaW 46-47 (Edwin Hees trans., 1992) (explaining limitations and expanse of Dutch common law in South African courts).

The Dutch law on sodomy also influenced early American law. The 1646 Calendar of Dutch Historical Manuscripts contains two of the earliest reported convictions for sodomy in the American colonies, both occurring on Manhattan lsland in the New Netherland Colony. See JoNATHAN NED Katz, Gay American History: Lesbians and Gay Men IN tHE U.S.A. 22-23 (1976). The Dutch reliance on religious texts and fervent retribution figured prominently in these cases. Id. (Calender of Dutch Historical Manuscripts reporting that the accused had been found guilty of "sodomy; second offense; this crime being condemned of God (Gen., c. 19; Levit., c. 18:22, 29) as an abomination, the prisoner is sentenced to be conveyed to the place of public execution, and there choked to death, and then burnt to ashes ....").

152. C.R. SNYMAN, STrafreg 388, 390 n.3 (1992); Edwin Cameron, Sexual Orientation and the Constitution: A Test Case for Human Rights, 110 S. African L. J. 450, 453 (1993); De Vos, supra note 138, at 274-75. See also Caineron, supra at 91 (briefly explaining origins of South African sodomy law in Roman law).

Notably, the American colonies in general also incorporated analogous, broadly defined conceptions of sodomy, the scope of which (like South Africa) gradually changed over time. Anne B. Goldstein, Comment, History, Homosexuality, and Political Values: Searching for the Hidden Determinants of Bowers v. Hardwick, 97 YALE L.J. 1073, 1082-86 (1988) (discussing American colonial incorporation of sodomy laws and subsequent historical changes in the offense's definition). Jonathan Katz argues that sodomy laws were instituted by European settlers in America to control for a range of nonprocreative sexual energies that the colonists pereeived would interfere with economic production and population growth. JONATHAN NED KATZ, THE INVENTION OF HETEROSEXUALITY $37-$ 40 (1995). Katz's theoretical explanation should similarly apply to the South African colonies. It would also dovetail with De Vos's view of the colonial experience as a significant factor in the cultural production of sexuality and its political regulation. 
The prohibition of sodomy had an extended life within the common law due to a combination of historical circumstances. Although England took control of the Cape in 1795, Roman Dutch law remained the law of the land in accordance with the rules of colonial succession. ${ }^{153}$ Hence, as the Dutch Republic's common law was ironically dying out back home, the Roman Dutch common law in South Africa was basically severed and left to survive on its own. ${ }^{154}$

Two events help explain the wane of the common law in the Dutch Republic and the resulting South African divergence with regard to the criminalization of sodomy. By the early nineteenth century, Holland had beconie part of a continent-wide codification movement, a development which left few interstices for common law to develop and, as a consequence, less of it to carry over to South Africa. ${ }^{155}$ Napoleon's annexation of Holland in 1810 also introduced the country to the French penal code, a generally more liberal system of criminal justice especially with regard to our topic: the French code did not impose criminal sanctions for sodomy. ${ }^{156}$ These legal developments, however, did not extend to South Africa. Rather, as mentioned above, the codification initiatives entailed the permanent separation of the Dutch common law from the Roman Dutch system. Had South Africa continued to operate under Dutch rule, or had the British conquered the Cape several years later, perhaps the criminalization of sodomy would have been modified or rejected. ${ }^{157}$

153. The British abided by the rule that conquered states should be allowed to maintain their system of law unless specifically superseded by subsequent acts of the conqueror. See Campbell v. Hall, 1 Cowp. 204, 209 (1774) ("The laws of a conquered country continue in force until they are altered by the conqueror.... [T] he King has power to alter the old and to introduce new laws in a conquered country...."). This rule was hypocritically not applied when it came to the laws of indigenous African communities. See DU PLESS1s, supra note 151, at 62-65 (analyzing the absorption of indigenous legal systems by Dutch and British colonial regimes).

154. Du PLESS1S, supra note 151, at 44-45, 47.

155. Id. The precedential effect of post-1652 legislation on the Cape colony (especially after British annexation) was dubious. Id. at 46-7. The South African Roman Dutch common law subsequently "did not have a foreign source from which it could grow: it became purely indigenous." Id. at 47. Notably, in 1809, Holland's first national criminal code contained moderate reform in the area of sodomy laws; it changed the crime from a capital offense to one with a maximum penalty of life inprisonment. See Huussen, supra note 151, at 146.

156. Huussen, supra note 151 , at 146 (characterizing introduction of French penal code's view on sodomy as liberal dawming of "a new chapter"). But see D.A. Coward, Attitudes to Homosexuality in Eighteenth-Century France, in History of Homosexuality IN Europe AND AMerica 35, 36 (Wayne R. Dynes \& Stephen Donaldson eds., 1992) (contending that generally worded provisions of Napoleonic Code permitted prosecution of same-sex practices).

157. Such conjecture is just that: conjecture. Progressive developments in Holland might have been resisted by the expatriate community in South Africa. Furthermore, Britain's subsequent control might have reversed any positive gains. For example, in the late nineteenth century, South African provincial legislatures enacted anti-sodomy statutes that were influenced by, if not directly modeled on, English laws. De Vos, supra note 138, at 276 (discussing English law's influence on provincial legislatures). It is an open question whether greater progressive influences in the Cape colony prior to England's control could have moderated such initiatives. 


\section{The Modern Era: The Preservation of Sodomy Laws}

The criminalization of sodomy under Roman Dutch law survived well into the twentieth century. Indeed, the Roman Dutch common law contained a built-in conservative pull: despite South Africa's earlier rule as a British protectorate and its later independence, the old Roman Dutch jurists and the decisions of centuries-old Dutch courts retained special precedential weight as sources of law within the judiciary's rules of interpretation. ${ }^{158}$ Accordingly, South African courts were guided by views on sodomy laws that were dominant prior to the early nineteenth century. ${ }^{159}$ This connection was especially unfortunate because the eighteenth century Dutch common law had developed during a period in Holland when massive waves of persecutions took place for acts of sodomy. ${ }^{160}$

Nevertheless, the South African common law crime of sodomy, and more generally of "unnatural offenses," gradually adapted to changes in popular values. Most significantly, in its modern incarnation, the legal definition of sodomy no longer applied to male-female or female-female relations. The crime of sodomy in South African courts only referred to sexual acts between men. ${ }^{161}$ Apparently, this part of the prohibition was retained due to persistent social prejudice against male homosexuality. A leading South African criminal law textbook, for example, argued that the continued criminalization of male-male sex was legitimate due to durable popular abhorrence of such practices. ${ }^{162}$

As of late 1998, the criminal law in South Africa still contained a number of statutes and judicial precedents that criminalized acts of sodomy. ${ }^{163}$ The common law criminalized male-male sex under the rubric of sodomy and "unnatural sexual offenses." Sodomy was also desiguated a criminal offense by statute. The Criminal Procedure Act 51 of 1977 specified sodomy as a Schedule 1 offense, a category of particularly serious

158. Du PLessis, supra note 151, at 45; T.P. Van Reenen, The Relevance of the Roman (Dutch) Law for Legal Integration in South Africa, 12 S. Afr. L.J. 276, 278-79 (1995).

159. See, e.g., Rex v. S. 1950 (2) SALR 350 (referring to old Roman Dutch law to determine whether male-male "touching ... of private parts" without physical gratification constituted unnatural offense); S. v. Cebekulul, 33(3) SA 221 (n) 16, 17-18 (1966) (following old Roman Dutch prohibition against mutual masturbation).

160. Huussen, supra note 151, at 144-45 (providing historical account of three waves of persecution in 1730, 1764, 1776). A landmark South African sodomy case demonstrates the nature of such gravitational commitments. In the 1926 case Rex $v$. Gough and Narroway, the court predicated its holding, in significant part, on the ancient prohibitions of sodomy that were validated by the early Dutch common law and the works of ancestral jurists. Rex v. Gough \& Narroway, 1926 C.P.D. 159, 161 CPD 159, 161 (on file with author). See also Cunningham v. Cunningham 1952 (1) SALR 167, 169(A) (on file with author).

161. Cameron, supra note 152, at 453.

162. Id. at 458 (citing $2 \mathrm{~J} \mathrm{R} \mathrm{L} \mathrm{Milton} \mathrm{SA} \mathrm{Criminal} \mathrm{Law} \mathrm{and} \mathrm{Procedure:} \mathrm{Common} \mathrm{Law}$ CRIMEs 270-71 (1990)).

163. See Barbara Adair, Sexual Orientation-What the Law Says, Equalrry 3 (July-Sept. 1995) (explaining the various statutory and common law prohibitions against same-sex sexuality). 
offences including murder, fraud, and rape. ${ }^{164}$ The somewhat bizarre Section 20A of the Sexual Offences Act 23 of 1957, known as the "men at a party" statute, outlawed sexual gratification between men when more than two men (hence a "party") were present. ${ }^{165}$ Additionally, age of consent laws treated same-sex partners differently than male-female partners. ${ }^{166}$ Sex between same-sex partners was a criminal offense if one of the partners was under the age of nineteen. ${ }^{167}$ Sex between a male and female, however, was a criminal offense if one of the partners was under the age of sixteen. ${ }^{168}$ Only the age of consent laws expressly prohibited acts between females, though the cominon law crime of "unnatural sexual offenses" could have conceivably applied to lesbian couples as well. ${ }^{169}$

In the last two decades, South African sodomy laws remained on the books, but like their American counterparts, they were generally not enforced. From the 1950s to the 1970 s, the South African police regularly harassed individuals under the auspices of these laws. ${ }^{170}$ However, that era, what lesbian and gay South Africans refer to as their own "pre-Stonewall" years, ${ }^{171}$ was succeeded by a legal regime $\mathrm{m}$ which the formal powers of the criminal justice system were generally not visited on lesbians and gays. Professor Edwin Cameron, probably the leading authority on sexual orientation law in South Africa, explamed the dormant character of sodomy laws' enforcement: "These laws are seldom enforced. On the contrary, most Attorneys-General (the chief regional law enforcement executives of

164. $\$ \$ 40,42,49$ of Criminal Procedure Act of 1997, 1998 (1) JSRSA 2-277-78. A Schedule 1 offense allows police officers to arrest, without a warrant, any person suspected of committing the prohibited act. It also allows the police to use deadly force against a suspected offender when that individual cannot be arrested or prevented from fleeing.

165. The statute provides: "A male person who commits with another male person at a party any act which is calculated to stimulate sexual passion or to give sexual gratification, shall be guilty of an offence." $\$ 20 A(1)$ of Sexual Offences Act 23 of 1957, 1998 (1) JSRSA 2-246. The statute further explains that "a party" means any occasion where more than two persons are present." Id. at $\S 20 \mathrm{~A}(2)$. The political battles and comprises that gave rise to this bizarre wording are discussed at length in Mark Gevisser, A Different Fight for Freedom: A History of South African Lesbian and Gay Organizationthe I950s to 1990s, in Defiant DesiRe, supra note 135, at 14, 30-35.

166. $\$ \$ 14(1)(b) \& 3(b)$ of Sexual Offences Act 23 of 1957, 1998 (1) JSRA 2-245.

167. Id.

168. $\$ \$ 14(I)(a) \& 3(a)$ of Sexual Offences Act 23 of 1957,1998 (1) JSRA 2-245.

169. Such an application to female couples would have been unlikely given that both the late 1960 s and late 1980s legislative drives to enact a female-female age of consent law considered and rejected extending the criminal prohibition against consensual sex to adult women. See Gevisser, supra note 165 , at 31,35 (providing history of 1960 s statutory initiative); see also id. at 60 (relating the background history of special President's Council's Ad Hoc Committee's recommendation in 1988 to investigate "the possible widening of the criminal prohibitions on gay conduct to include gay women") (quoting President's Council's Ad Hoc Committee).

170. See Gevisser, supra note 165, at 30-31, 46-47; Glen Retief, Keeping Sodom Out of the Laager: The Policing of Sexual Minorities in South Africa, in DefIANT DESIRE, supra note 135, at 99, 99-103.

171. Gevisser, supra note 165, at 47 ("Many South African gay people refer to the 1979 Mandy's Raid ... as South Africa's 'Stonewall."'). 
the Department of Justice) have indicated in private that they will not prosecute gay adult men who have gay sex in private or who 'party' at gay venues." "172 According to official sources in South Africa's Western Cape, no case of private consensual sodomy had been prosecuted since 1972, a fact which accorded with the internal (though unofficial) policy of that region's Office of Attorney General. ${ }^{173}$ Neither the Cape Town Regional Magistrate's Court nor the Wynberg District Magistrate's Court had any record of a single prosecution. ${ }^{174}$ Although the threat of arrest weighed on the minds of individuals interviewed for this Article, none of them had ever been arrested and they had no knowledge of anyone who had been arrested.

\section{The New South Africa: The Judicial Invalidation of Sodomy Laws}

All of the criminal laws mentioned above, with the exception of the age of consent statutes, were struck down in October 1998 by South Africa's Constitutional Court. ${ }^{175}$ In a landmark decision, National Coalition for Gay and Lesbian Equality v. Minister of Justice, ${ }^{176}$ the Court held that sodomy laws violated the constitutional rights to dignity and privacy and the guarantee of equality. ${ }^{177}$ The decision represented the most meaningful judicial victory for the gay rights movement since the abolition of apartheid.

The outcome of the sodomy litigation was not a foregone conclusion. On appeal to the Constitutional Court, the Minister of Justice, in an

172. Cameron, supra note 152, at 92 ; Retief, supra note 170 , at 103 ("In more recent years, police have stopped the constant harassment of gay bars and social gatherings and have kept a lower profile with respect to lesbian, gay and bisexual communities. Since the 1980 s gay bars have operated without attempts being made to close them down ...."); cf. Gevisser, supra note 165, at 43 (noting that "even though the anti-sodomy laws were 'sleeping' and seldom applied" this did not foreclose police use of common law sodomy offenses in early 1970 s harassment of gay organizations).

173. IsAACs \& MCKENDRICK, supra note 136, at 153 (detailing information from communication with Attorney General's Office).

174. Id. These reports help explain why some commentators cite statistics from the South African Central Statistical Services (CSS), claiming the continuation of a certain level of enforcement of sodomy laws and "unnatural sexual offenses." See id. at 151; Kevan Botha \& Edwin Cameron, Sexual Privacy and the Law, 4 S. Afr. Hum. RTs. Y.B. 1993, at 219, 223-26 (Neil B. Boister ed., 1994); De Vos, supra note 138, at 275 n.44. Most of these prosecutions concern public sexual offenses. See ISAACS \& MCKENDRICK, supra note 136, at 151-52 (clarifying that statistics do not dispute lack of enforcement against sodomy between gay men in private). It is also uncertain what percentage of these figures represent charges of nonconsensual acts. See Botha \& Cameron, supra at 225 (explaining that prosecutions for "unnatural sexual offences" in 1992 were apparently against consenting adults, without making a similar claim for sodomy prosecutions). As an illustration, the Western Cape, which comprises over sixty percent of the CSS's reported prosecutions and convictions, is the saine region in which there has not been a single prosecution for private, consensual sodomy since 1972. See IsAAcs \& MCKENDRICK, supra note 136, at 153.

175. Nat'l Coalition for Gay and Lesbian Equal. v. Minister of Justice, 1998 (12) BCLR 1517 (CC). The age of consent laws were not a part of the sodomy litigation. The civil rights group that brought the action, however, has since begun planning a suit on the age of consent laws as well.

176. Id.

177. Id. 
unanticipated move, decided to oppose the plaintiffs' petition. ${ }^{178}$ In an initial public statement, the Minister stated, "I respect the rights of gays and lesbians as guaranteed in our New Constitution. The rights of gays and lesbians and those of the public have to be balanced."179 The Minister of Justice subsequently withdrew his motion of opposition, ${ }^{180}$ but only after the plaintiffs ainended their request for remedial relief to comply with some of his objections. ${ }^{181}$

Similarly, the plaintiffs could not be assured of a favorable response from the Court. Admittedly, the Justices' political leanings were generally reflective of the governing African National Congress, an exceptionally progressive party. Such ideological monikers, however, had already proven a disappointment to lesbian and gay rights organizations lobbying the legislature. When the ANC-dominated Parliament convened in its role as the Constitutional Assembly to draft the new Constitution, lesbian and gay rights organizations barely succeeded in getting the sexual orientation clause included in the final text. ${ }^{182}$ Part of the difficulty lay in the fact that the ANC's membership was deeply divided over the issue of

178. Minister Omar's initiative was surprising because another division of the ANC government, the Human Rights Commission, was one of the plaintiffs in the case. According to popular speculation, Minister Omar had made his decision on the basis of prospective political aspirations: a future in which he would likely try to draw support from South Africa's more conservative Indian community.

179. Ministry of Justice, Press Statement by the Minister of Justice, Dr A. M. OMar MP, Regarding a Court Case by the Human Rights Commission and the National Coalition For Gay and Lesbian Equality Brought Against the Ministers of Justice and SafeTy and SEcurITY, Sept. 3, 1997 (on file with author). The Chairman of the Justice Committee, Johnny de Lange, also stated: "clearly if there is an equality clause in the constitution then that must be taken into account, but no right is absolute, as there is a limitation clause." No Rights for Gays When It Comes to the Law, THE STAR, Sept. 10, 1997 (on file with author).

180. Although the Minister of Justice ended his opposition to the appeal, he did not support it either. Some speculated that this stance, and the similar stance by other defendants named in the action, meant the plaintiffs would not have an easy time convincing the Court. One joumalist wrote:

The application has been brought against the Minister of Justice, the Minister of Safety and Security and the attomey-general of the Witwatersrand, although none of the three is opposing the application, nor are they lending it their support, which will mean advocate Gilbert Marcus will have to present a convincing argument for the removal of the legislation.

Charlene Smith, Sodomy Laws in Firing Line, Saturday Argus, Nov. 25, 1997 (on file with author).

181. The Minister of Justice had argued that aspects of the plaintiffs' petition for retrospective relief would entail excessive and unpredictable changes in police discipline and law enforcement. Ministry of Justice, Press Statement by the Minister of Justice, Dr A. M. OMar MP, Regarding the Application brought by the Nationaol (sic) Coalition for Gay and Lesbian EqualitY, Sept. 18, 1997 (on file with author); see also Jermaine Craig, Courts Must Debate Gay Laws Omar, THE STAR, Sept. 10, 1997 (on file with author). The plaintiffs removed that aspect of their request within weeks of the Minister's complaint. ApPLICANT's HEADS OF ARGUMENT; Nat'l Coalition for Gay and Lesbian Equal. v. Minister of Justice, CASE No. CCT11/98 (on file with author).

182. For an insightful history of the pohtical background and tenuous nature in which the sexual orientation clause was included in the Constitution, see Eric C. Christiansen, Note, Ending the Apartheid of the Closet: Sexual Orientation in the South African Constitutional Process, 32 N.Y.U. J. INT'L L. \& POL. 997 (2000). 
homosexuality. ${ }^{183}$ Lesbian and gay rights advocates, therefore, worried about the depth and durability of the ANC's commitment to sexual orientation rights. ${ }^{184}$ In the decriminalization campaign itself, lesbian and gay rights organizations had first turned to the ANC-dominated Parliament, but met with considerable intransigence. Admittedly, at the time, the Ministers of Parliament were busy fashioning the founding legislation for the postapartheid state. Regardless of the underlying motivation for the lack of legislative reform in the area of lesbian and gay rights, the lack thereof became the primary reason the groups decided to direct their decriminalization efforts to the judiciary. ${ }^{185}$ Because arguments on the basis of the Constitution's equality clause had not worked with Ministers of Parliament, however, it might not compel the Justices either. The Justices could hide behind twists in legal reasoning-such as distinctions between statusbased versus conduct-based discrimination ${ }^{186}$ or jurisdictional concerns $^{187}$ - to avoid issuing a decision on such a politically sensitive matter.

Another reason to harbor doubts about the outcome of the case related to a series of recent lower court decisions. In the previous five years, three important lower court judgments had been handed down, with mixed outcomes. One decision was clearly negative. The court restricted the custodial rights of a lesbian mother on the basis of the judge's homophobic common sense: "[A]ny right-thinking person would say that it is important that the children stay away from confusing signals as to how the sexuality of the male and the female should develop." 188 The two other cases, $S . v$. $H .{ }^{189}$ and State $v$. Kampher ${ }^{190}$ directly involved sodomy laws, and the judges in these cases questioned whether sodomy could be considered a

183. Significant rifts within the ANC over lesbian and gay rights were clearly evident before and during the transition. See Derrick Fine \& Julia Nivol, The Lavender Lobby: Working for Lesbian and Gay Rights Within the Liberation Movement, in DEFIANT DESIRE, supra note 135, at 270-72.

184. See Gevisser, supra note 158, at 74 ("[G]iven the evidence up to 1993, it would be premature to suppose that the lesbian and gay movement can be assured of support from a future ANC govermment. Official ANC support of gay issues has been at worst grudging and at best half-hearted."); Rachel Holmes, "White Rapists Made Coloureds (and Homosexuals)": The Winnie Mandela Trial and the Politics of Race and Sexuality, in DEFIANT DESIRE, supra note 135, at 291 (maintaining that despite the then-draft constitution's clause on equality, recent signs of homophobia within factions of the ANC "should be the clearest warning yet that documentary commitments do not guarantee correlative action, protection and support from either an umbrella liberation organization or a future government").

185. Telephone Interview with Jonathan Berger, Former Coordinator, Gay and Lesbian Legal Advice Centre, National Coalition for Gay and Lesbian Equality (Jan. 18, 2001).

186. As suggested by the U.S. federal court cases discussed above, judges may distinguish constitutional principles protecting against discrimination on the basis of sexual orientation (status) from constitutional principles allowing prohibitions against sodomy (conduct). See supra note 140.

187. For example, the Court could have invoked principles of standing, such as mootness, as a basis for dismissing the suit. See supra note 59 (discussing U.S. courts' reliance on standing doctrine in avoiding review of sodomy laws).

188. Van Rooyen v. Van Rooyen, 1994 (2) SALR 325, at 328-29.

189. S. v. H., 1995 (1) SA 120 (on file with author).

190. State v. Kampher, 1997 (4) SA 460. 
valid criminaI offence. However, as I explain below, neither of these cases gave lesbian and gay rights activists the complete victory they sought, and $S$. v. $H$. in particular created unnecessary, though possibly unintended, hurdIes for future plaintiffs to clear.

The troubling aspects of the $S$. v. $H$. decision were especially significant because the judge in the case, Judge L.W.H. Ackermann, had since become one of the more prominent members of the Constitutional Court. ${ }^{191}$ For the most part, Judge Ackermann's discussion in $S$. v. $H$. involved a strong criticism of the maintenance of sodomy laws. ${ }^{192}$ Nevertheless, he refrained from invalidating the laws. Instead, he substituted the defendant's one-year suspended sentence with a caution and discharge. ${ }^{193}$ At the conclusion of his opinion, Judge Ackermann also added some analytic ambiguities, effectively diminishing the strength of his objections to the laws. His analysis culminated in the following qualified statement: "[A]t the present time a custodial sentence is not an appropriate sentence for consensual, adult, private sodomy taking place under circumstances which pose no threat to any legitimate societal interest." ${ }^{194}$ In the final paragraph of his opinion, Judge Ackermann also added the following concern: "One possible qualification needs to be mentioned... There may be special situations where a legitimate societal interest might justify a different view being taken of private sodomy, even between consenting adults. The position of prison inmates comes to mind."195 Judge Ackermann then proceeded to explore a hypothetical situation concerning the regulation of prison inmates' sexuality, but he concluded that such regulations would have to apply to heterosexuals and homosexuals alike. This somewhat awkward and seemingly gratuitous aside at the end of his opinion, in light of his earlier qualified statements, rendered Judge Ackermann's position on the subject (and the law im general) uncertain.

Some of Judge Ackermann's ambiguous language was subsequently adopted by a magistrate judge in order to justify the conviction of a prisoner for sodomy and the imposition of a suspended one-year sentence. ${ }^{196}$ The magistrate quoted at length from Justice Ackermann's opinion and

191. Notably, Justice Ackermann would also author the Court's opinion in National Coalition for Gay and Lesbian Equality v. Minister of Justice, 1998 (12) BCLR 1517 (CC).

192. For example, he quoted at length from the dissenting opinions in Bowers v. Hardwick and stated his approval of many of Justice Stevens' and Justice Blackmun's conclusions therein. $S . v . H$, 1995 (1) SA at 126-27.

193. Id. at 129.

194. Id. Implicit in this statement is the fact that a sentence might still be justified, just not a custodial sentence. The judge's decision to give the defendant a caution in the case supports this conclusion. Furthermore, the nature of Judge Ackermann's qualification, namely, that his stateinent applies to acts of sodomy that occur "under circumstances which pose no threat to any legitimate societal interest," seems gratuitous for one interested in seeing the complete invalidation of the laws.

195. S. v. H, 1995 (1) SA at 129.

196. State v. Kampher, 1997 (4) SA 460, 462 (quoting magistrate's opinion). 
then stated: "This current incident occurs in prison, and therefore the words of the Honorable Justice Ackerman [sic] are respectfully correct when stating 'There may be special situations' and later 'consenting adults undergoing imprisonment could well serve a legitimate societal interest." 197 The magistrate concluded:

In my humble opinion the accused should receive a message that he is fully within his right to exercise his sexual preference, yet within reasonable bounds. The rights and interests of non-homosexual males in prison must be protected. It is desirable that they should not be exposed to the homosexual activities of others, albeit visually or otherwise. In my opinion, the incident was not "cloaked" in full privacy.

Furthermore, I am of the humble opinion that the continued practice of sexual relations in prison is undesirable.

... Although the sentence is one of suspended imprisoument, it is my humble opinion that through this, the message as stated [above] is brought home to the accused. ${ }^{198}$

Based on this logic, the magistrate requested the appeals court to reject the defendant's appeal and confirm both the conviction and sentence. ${ }^{199}$

On review, the appeals court, in State $v$. Kampher, ${ }^{200}$ rejected the magistrate's views and set aside both the conviction and sentence, thus straightening out some of the wrinkles caused by Judge Ackermann's opinion. The Kampher court issued a lengthy critique of the continued viability of sodomy prosecutions under the new constitutional dispensation. In doing so, the court also marshaled authorities from various foreign sources such as American scholarship and judicial opinions, European case law and legislation, and international human rights treaty law. ${ }^{201}$ The court,

197. Id. ("Die huidige voorval vind plaas in die gevangenis en daarom is die woorde van Sy Edele Regter Ackerman [sic] met respek korrek as gemeld word dat 'there may be special situations' en later 'consenting adults undergoing imprisonment could well serve a legitimate societal interest."') (translation by Charl du Plessis).

198. Id. at 462-63 (quoting magistrate's opinion) ("'Ek is respekvol van oordeel dat beskuldigde ' $n$ boodskap moet kry dat hy die volste reg het om sy seksuele voorkeur uit te oefen, maar dat dit binne perke gedoen moet word. Die regte en belange van nie-homseksuele mans in die gevangenis moet beskerm word. Dit is so dat dit wenslik is dat hulle nie blootgestel word aan homoseksuele dade van ander nie, hetsy visueel of andersins. Die voorval was myns insiens ook nie in volle privaatheid gehul nie. $E k$ is voorts respekvol van oordeel dat die handhawing van seksuele verhoudings in die gevangenis ongewens is. . . Hoewel die vonnis een is van opgeskorte gevangenisstraf, is dit verder my respekvolle siening dat die boodskap soos gemeld in para 6 hierdeur wel aan beskuldigde oorgedra word.") (translation by Charl du Plessis).

199. Id. at 463 (quoting magistrate's opinion) ("The Honourable Justice of Review is respectfully requested to confirm both conviction and sentence.") ("Sy Edele die Hersieningsregter word derhalwe respekvol versoek om skuldigbevinding en vonnis te bekragtig.") (translation by Charl du Plessis).

200. Id.

201. See, e.g., id. at 460-61 (listing 16 United States court opinions and 5 Canadian ones); id. at 484-85 (quoting Thomas C. Grey, Bowers v. Hardwick Diminished, 68 U. Colo. L. Rev. 373, 384-86 (1997)). 
however, appeared to confine its holding to the conviction in the case at hand, rather than striking down the laws in general. Still, the opinion in Kampher was indicative of the forthcoming Constitutional Court decision and the general shape of the new South African legal order. ${ }^{202}$

Within one year after Kampher, the Constitutional Court decided National Coalition for Gay and Lesbian Equality. ${ }^{203}$ Justice Ackermann, writing for the Court, relied heavily on foreign sources of law including Justice Blackmun's dissenting opinion in Bowers and several American law review articles. ${ }^{204} \mathrm{He}$ also referred repeatedly to then-Professor (now Judge) Edivin Cameron's leading article on the subject. Most importantly, the opinion quoted a particularly moving statement froin Cameron: the criminal laws, Cameron wrote, "[e]ven when ... not enforced ... reduce gay men ...to what one author has referred to as 'unapprehended felons." "205 Underlying Cameron's pointed characterization of the sodoiny laws lies a complex and profound relationship of law to people's everyday lives. The following Part attempts to relate and analyze the broader social experiences to which Cameron's remark alludes.

\section{III}

\section{The Micro-Sociological Dimension of Sodomy Laws}

\section{A. Before the Abolition of Sodomy Laws}

\section{Locations of Regulation and Social Panoptics}

Sodony laws interact with other forms of societal censure to produce a geography of oppression. The following discussion of neighborhood animosity and public surveillance reveals how even the most personal spaces are often regularized by a disciplinary control. For a lesbian or gay person, two locations, one's hoine and popular gay-friendly places, offer the best prospect of safety and security. Other areas, includimg the general

202. Jennifer C. Lukoff, Comment, South Africa Takes the Initial Step Towards a Brilliant Twenty-First Century: A Comparative Study of State v. Kampher \& Bowers v. Hardwick, 18 N.Y.L. ScH. J. INr'L \& CoMP. L. 459 (1999).

203. Nat'1 Coalition for Gay and Lesbian Equal. v. Mmister of Justice, 1998 (12) BCLR 1517 (CC), 1998 SACLR LEX1S 36.

204. See, e.g., id. at 145 (citing Bowers v. Hardwick, 478 U.S. 186, 205-214 (1985) (Blackmun, J., dissenting); id. at $\approx 84$ n.78 (citing Thomas C. Grey, Bowers v. Hardwick Diminished, 68 U. CoLo. L. Rev. 373 (1997)); id. at $\neq 71$ n.48 (citing John M. Finnis, Law, Morality and "Sexual Orientation," 69 Notre Dame L. Rev. 1049 (1994)); see also id. at $\neq 141$ n.125 (Sachs, J., concurring) (citing Patricia Williams, Response to Mari Matsuda, 11 WoMEN's RTs. L. REP. 11, 11 (1989)); id. at *163 n.161 (citing Christine A. Littleton, Reconstructing Sexual Equality, 75 Calm. L. Rev. 1279, 1285 (1987)).

205. Nat'l Coalition for Gay and Lesbian Equal., 1998 SACLR LEXIS at 55 (citing Edwin Cameron, Sexual Orientation and the Constitution: A Test Case for Human Rights, 110 S. AFr. L.J. 450,455 (1993). Notably, the Kampher court and Justice Ackermann in his $S$. v. H. decision had also chosen to quote from Cameron's discussion. See Kampher, 1997 (4) SA 460 at para. 25; S. v. H., 1995 (1) SA 120, 127. 
public domain, may raise concerns of physical security or mental distress. The discussion that follows describes the ways in which lesbian and gay South Africans negotiate these spaces. Most places either require or condone only practices that conform to a heterosexual presumption. ${ }^{206} \mathrm{Here}$, lesbian and gay couples are generally able to pass, but at the cost of concealing romantic or intimate affection or other signs of their sexual identity. Even more inhospitable are areas where lesbian and gay people, especially open couples, do not think of venturing. In contrast to all these are safe zones, locations that may either permit, favor, or actually encourage lesbian and gay people to feel free and act freely.

Spatial locations present various threats and manifestations of power, and sodomy laws intersect this field in multiple ways. As the following accounts reveal, many lesbian and gay individuals believe that sodomy statutes directly or indirectly proscribe various displays of public affection between same-sex partners. For these individuals, laws frame and help produce conditions of hostility and create the need for self-monitoring in public space. Safe areas, in contrast, are marked off by lack of detection and relative freedom from the law. Yet, the absence of the law and law enforcement in these places also creates an exposure to other risks. For example, local thugs often know they can prey on lesbians and gays outside gay bars. And many lesbian and gay people think their own criminal status precludes them from claiming state protection or filing a complaint.

In the discussion that follows, readers might have a nagging feeling that generalized homophobia and societal stigma are also responsible for some of these social effects. Of course there is an obvious truth to such an intuition, for the sociological complexities of societal phobia cannot be reduced to a single cause. That said, there are at least three reasons to believe that this examination of sodomy laws can afford unique insight into how homosexual identities and individuals' behaviors are constituted and self-regulated. First, law and legal prohibitions are a part of the equation of social control which operate in the lives of lesbians and gays through the mechanism of generalized stigmatization itself. Isolating the legal dimension and studying it can contribute significantly to our understanding of the general phenomenon of stigmatization and social control of homosexuality. ${ }^{207}$ Second, the remarkable fact, identified in the discussion of the interviews that follow, is how often the law is implicated or invoked in various social relations and processes of identity formation. As it turns

206. Cf. Tobias Barrington Wolff, Compelled Affirmations, Free Speech, and the U.S. Military's Don't Ask, Don't Tell Policy, 63 BRook. L. Rev. 1141, 1144 (1997) ("[T]here is a presumption of heterosexuality that pervades our lives. In all but the most unusual of circumstances, people will assume that any given individual is straight unless they have reason to believe otherwise. That assumption informs every conversation and interaction.").

207. See Leslie, supra note 84 , at 105. Part IV elaborates the need to acknowledge law's role in the context of other social forces at a macro-sociological level. 
out, law too plays a significant role. Finally, this Article's discussion of social interactions that occurred in South Africa after the sodomy laws were abolished substantiates the significance these laws had in people's lives. The findings indicate not only that lives were changed by the absence of sodomy laws, but that the critical transforming event of invalidating the sodomy laws contributed significantly to changes in behavior and outlook.

The following discussion is organized according to the spatial areas in which lesbians and gays negotiate their lives. I begin the discussion by examining the force sodomy laws exert in the most local of places: relationships to oneself, to home, to neighborhood, and to local community. My discussion then expands into a consideration of the broader social space outside the confines of the lone self and beyond one's immediate residence. In this broader domain, the physical setting is the wider public arena; the conditions of oppression here are characterized by a dynamic intersection of legal rules and the visibility of lesbians and gays under a social gaze.

This last point requires further theoretical elaboration before turning to the discussion itself. The concept of regulation through visibility and surveillance is borrowed from Michel Foucault. The relevant aspect of Foucault's work is his analysis of the Panopticon, Jeremy Bentham's architectural innovation for perfecting social control within a penitentiary. ${ }^{208}$ Foucault used the structural design of the Panopticon to illustrate the effect of subjugating habits, thoughts, and deeds through an all-encompassing mode of surveillance. The blueprint for Bentham's Panopticon was fairly simple. A tall, observational tower was situated at the center of the prison. The tower's observational deck had large open windows which looked out onto a ring of prison cells below. Each cell along the ring contained two windows, one on the inside in view of the tower, and the other on the outer wall allowing the light to pass through and illuminate the prisoner's rooin. ${ }^{209}$ This architectural innovation

reverses the principle of the dungeon; or rather of its three functions--to enclose, to deprive of light and to hide-it preserves only the first and elimmates the other two. Full lighting and the eye of a supervisor capture better than darkness, which ultimately protected. Visibility is a trap. ${ }^{210}$

208. Michel Foucault, Discipline and Punish: The Birth of The Prison 200 (Alan Sheridan trans., Vintage Books ed. 1979) (1978). Other scholars have also used Foucault's discussion of the Panopticon to describe particular social dynamics related to the regulation of sexuality. See, e.g., Kenji Yoshino, Assimilationist Bias in Equal Protection: The Visibility Fresumption and the Case of "Don't Ask, Don't Tell," 108 Yale L.J. 485, 545 (1998); Kath Weston, Families We Choose: Lesbians, Gays, Kinship 163 (1991).

209. FoucaulT, supra note 208, at 200.

210. Id. 
Foucault explains the resulting impact: "Hence, the major effect of the Panopticon: to induce in the inmate a state of conscious and permanent visibility that assures the automatic functioning of power."211

The state's relationship to lesbian and gay individuals under a regime of sodomy laws constructs a similar, yet dispersed, structure of observation and surveillance. The public is sensitive to the visibility of lesbians and gays as socially and legally constructed miscreants. Admittedly certain individuals, namely those who are certified with various levels of state authority, are more directly linked to the extension of law's power. Yet the social effects of sodomy laws are not tied to these specialized agents alone. On the ground level, private individuals also perform roles of policing and controlling lesbian and gay lives in a mimetic relation to the modes of justice itself. ${ }^{212}$

The outcome of this political matrix is the creation of (legal) visibility and an encompassing social gaze. In later interviews, Foucault described this as the dispersion of "panoptisms" in which the state apparatus does not exclusively exercise the function of surveillance and control; instead, this power and its processes are channeled through individual actors throughout the social body:

The Panoptic system was not so much confiscated by the State apparatuses, rather it was these apparatuses which rested on the basis of small-scale, regional, dispersed Panoptisms. In consequence one cannot confine oneself to analysing the State apparatus alone if one wants to grasp the mechanisms of power in their detail and complexity. There is a sort of schematism that needs to be avoided here ... that consists of locating power in the State apparatus, making this into the major, privileged, capital and almost unique instrument of the power of one class over another. In reality, power in its exercise goes much further, passes through much finer channels, and is much more ambiguous, since each

211. Id. at 201. The mechanism of visibility might not always serve to regulate or oppress marginalized groups. Professor Kenji Yoshino persuasively argues that social context determines whether visibility or invisibility serves to empower or disempower members of marginalized groups. See Yoshino, supra note 208, at 537. At the same time, Yoshino calls for analyses of social contexts to "recogniz[e] the power of the state to make a group's mutability or invisibility an immense liability to that group." Id. at 538.1 attempt to heed Yoshino's words by examining the process by which the state and the mechanism of visibility regulate lesbians and gays in various public spaces.

212. In the concluding section to Discipline and Punish, Foucault discusses the grafting of the "prison-form" and the institutional model of justice onto other organized settings and social spaces. FoucAult, supra note 208, at 293-308. Individuals enact forms of the justice system-such as policing, judging, sentencing-in a copycat-like fashion within the modes and social relations of everyday life. 
individual has at his disposal a certain power, and for that very reason can also act as the vehicle for transmitting a wider power. ${ }^{213}$

Foucault's analytic insight is relevant to the issue of sodomy statutes and their local administration. Indeed, many lesbian and gay individuals regularly feel themselves under the eye of power. The following section concerns the expression of sodomy laws in the formation of personal identity and in discourse with family and neighbors. The subsequent analysis takes off from that discussion and opens onto the site of residences, migration routes, and public venues.

\section{Constituting Self}

Many people first learn about the existence of sodomy laws during their adolescence. For lesbian and gay individuals, the law tells them, at an early age, that they are outside the boundary of social acceptance. A common misunderstanding of the law is that it outlaws homosexuals or bans being gay. ${ }^{214}$ The distinction between conduct and identity is conflated, ${ }^{215}$ and one clear message sent is that homosexuals are delinquents; the law

213. Michel Foucault, Questions on Geography, in Power/KNowledge: Selected INTERVIEWS AND OTHER WrITINGS 1972-1977, at 63, 72 (Colin Gordon et al. trans., Colin Gordon ed., 1980).

214. NC, a social worker at a lesbian and gay health organization, explained: "If I had to draw up a composite of my clients, I would say they do not understand the laws. They are under the impression that homosexuality, not just sodomy, is against the law." Interview with $\mathrm{NC}, \uparrow 12$, in South Africa (July-Aug. 1995) (on file with author). See also Interview with TG, $\uparrow 2$, in South Africa (July-Aug. 1995) (on file with author) (describing understanding of sodomy statutes as "laws that don't accept any gay relations"); Interview with MN, $\varsubsetneqq$ 2, in South Africa (July-Aug. 1995) (on file with author) (stating, when asked to define sodomy laws, "being homosexual in South Africa is illegal"). The fact that many lesbians and gays are afraid of discussing their feelings with friends or family makes it difficult for thein to gather clearer information about the law. For those who believe the law criminalizes being homosexual, it is even more unlikely for them to be open about their sexuality or raise questions about the law for fear of detection.

215. Paradoxically, one of the causes of this misinformation may have been public statements by lesbian and gay rights organizations. For example, a leading gay rights organization disseminated a flier announcing a public meeting to discuss ongoing political efforts. The flier stated: "Unjust laws still say that adult men who show love to each other are criminal." National Coalition for Gay and Lesbian Equality, Decriminalization of Same-Sex Conduct Volunteers Meeting, October 12, 1997 (flier) (on file with author). A spokesperson for the premier gay and lesbian rights organization was also quoted in a newspaper article as stating that lesbians and gays fear they are committing an offense "when they express love and affection towards each other." Prakash Najdoo, Gay Coalition Goes to Court to Stop Persecution of Men Who Party with Each Other, SundaY INDEPEndent, Aug. 24, 1997 (quoting Zackie Achmat, convenor of National Coalition for Gay \& Lesbian Equality) (on fle with author). Leading newspapers' coverage of the sodomy litigation also sent a confusing signal about what the law criminalized. For instance, in covering a regional court opinion which struck down a part of the sodony laws, a newspaper article stated the decision was a relief to "people whose sexuality has been condemned for centuries as a criminal offense." Adult Gay Sex Is Not a Crime, Court Rules, CAPE Arcus, Aug. 5, 1997 (on file with author). See also Pierre de Vos, The State, the Church and Homosexuality, THE CAPE TIMES, Aug. 26, 1997 (on file with author) (criticizing time it took for first South African Court "to come to the conclusion that gay men are not, by definition, criminals" in overturning sodomy conviction). Of course, some discussions of the subject appear to involve hyperbole or other rhetorical devices, but they add confusion to an already ambiguous law. 
signifies public abhorrence of lesbians and gays. Even for individuals who keep the distinction between act and identity fairly clear, the law unmistakably signals disapproval of homosexuality. This affects individuals' self-image both in their reflections of themselves and in their parents' assessments of them, another prism through which they perceive themselves.

\section{a. Self-reflection}

The societal condemnation expressed through the law shapes an individual's identity and self-esteem. Notably, many, if not most, individuals ultimately do not try to conform to the law's directive, but the disapproval communicated through it, nevertheless, substantively affects their sense of personal identity and their relationship to community. $R F$, one of my interviewees, talked about his wish to consider himself a "law-abiding" member of society, but the criminal laws made that image of himself unrealistic, unachievable. ${ }^{216}$ Another statement by RF, that "it [the law] makes you not be yourself," 217 indicates the internal contradictions (for example, how can a person be something she is not?), or rather the sense of disassociation from oneself, that the law can inspire. Another interviewee, BW, explained that he resented being labeled a criminal because he is a "citizen, who earns a living [and] pays taxes."218

Many lesbians and gays are determined to resist having their lives circumscribed or degraded by the law's expression of disapproval. Yet resistance itself defines one's sense of self and place in society. AP explained to me that, as a youngster, he was afraid of the laws and that his awareness of the laws' existence inade him feel "alone and inferior."219 Now twenty-nine years old, AP considers himself "a sexual radical.,"220 AP not only confronts those in authority who try to use the laws against him, he says he "courts disaster for the political end... to see how far authorities are willing to go in order to control gay sex."2221 AP told me of an occasion in which he dealt with a security guard who caught him having sex. He seemed to know he may easily get caught given the location: a restroom at a shopping center. AP felt that the guard was just trying to perform his job in evicting him from the premises. So, AP explained to the guard that although he sympathized with his position, the guard should understand the constraints gays have in meeting each other and in being able to have

216. Interview with RF, $\mathbb{3} 3$, in South Africa (July-Aug. 1995) (on file with author).

217. Id. (also श 3).

218. Interview with BW, II 20, in South Africa (July-Aug. 1995) (on file with author).

219. Interview with AP, ף 3 , in South Africa (July-Aug. 1995) (on file with author).

220. Id. If 8. Instead of calling himself gay or homosexual, as most of my interviewees would, AP also said he thought of himself "affirmatively [as] a faggot." Id. ๆ 1.

221. Id. \1 3 . 
sexually intimate relations. ${ }^{222}$ (The guard ultimately agreed with AP.) AP thought that if he were ever confronted with a police officer trying to arrest him for sodomy or a related charge he would do the same: "I would sit down with the cop and explain the illegitimacy of the law and the conditions which necessitate where I have sex."223

Although AP may be atypical in his method and capacity for direct confrontation, he shares much in common with a large category of people who resist internalizing law's degradation of homosexuality. Others commit themselves to resist internalizing the law's message, but they do not choose or hope to confront authority directly as AP does. However, like $\mathrm{AP}$, their identity is shaped through resistance. They consider their sexuality a defining part of their identity, one worth fighting for; they develop a self-identity that encompasses transgressive attitudes and behavior; and they are deeply suspicious of certain forms of authority.

The following words by a popular speaker, addressing a predominantly gay male audience at a fund-raising event, indicate the law's influence on self-identity in the process of working against its effects:

The simple fact is that male gays in South Africa have no legal right to practice their gayness. Almost every gay here this afternoon is, according to South African law, a criminal. ... ... We exercise the freedoin we think we might have in South Africa not by right but by favour, by indulgence. We are dependent on, at best, the goodwill of the police to meet and act as we do; and at worst we are dependent on their blind eyes, their lack of knowledge or their mefficiency. ${ }^{224}$

This statement indicates the type of attitudes and self-understandings individuals adopt through the process of resistance. The statement refiects a sense of being defined by the laws, offended or degraded enough to rise to action, and embracing an oppositional stance towards authorities. To claim that sodomy laws do not impact individuals who resist its dictates misses these consequences. Many lesbian and gay individuals' selfunderstanding and self-esteem are shaped in significant part by the criminal laws against homosexuality whether they internalize the law's expressive statement or resist it. ${ }^{225}$

222. Id. $\lceil 6$.

223. Id. ๆ 7.

224. Gevisser, supra note 165, at 60-61 (quotation marks omitted) (quoting Edwin Cameron, Benefit inaugural event, March 1986).

225. From his life history, GD appeared to be a person whose outward boldness (of a nature probably best described as brashness) was founded, in part, on his defiant view of himself in relation to the law and police. See Interview with GD, ๆ 3, in South Africa (July-Aug. 1995) (on file with author) ("These laws have not shaped my attitude towards myself. I suppose I am fairly arrogant. I have never had a guilt trip regarding the law, but it has shaped some of my experiences. That's different."). The following is one of several encounters with the police GD described: 


\section{b. Reflection of Self through Family}

In several interviewees' experience, the law appears to have bolstered their parents' fear and hostility towards homosexuality. This creates unique problems for lesbians and gays in terms of their self-identity and their sense of home as a place of sanctuary. For many lesbians and gays, the attitude their parents have towards homosexuality is an important factor not only in their adolescence, but also throughout their adulthood. Based on my interviews, it appears that parents' negative reaction to their child's "coming out" was often influenced by their perception of prevailing social norms, including an awareness of the laws against homosexuahity. The community's view of their child's sexuality, expressed in part through the law, was explicitly mentioned by the parents in some of these encounters. ${ }^{226}$ Other interviewees worried that the law, along with other social censures, would shape their parents' view and therefore they never revealed their homosexuality or intimate relations to their parents. JC, a woman in her mid-twenties relates her experience:

My father is Catholic and a lawyer. He goes very much by what the law says. As long as the law deems homosexuality to be immoral, he will react terribly if I ever try to tell him about my life. So, I am forced to lie to him about things that are the most important to me. ${ }^{227}$

Admittedly, JC's father may have a more pronounced sense of what the law dictates because of his professional training and experience as an attorney. However, one might also suspect that legal education teaches a

On one particular occasion I was blatantly insulted by the city council police at Sea Point. They called out, "You Queer!" I said back, "And?" They said some hateful statements, thimgs like I was offending God. I sent a written objection regarding this matter to the city council, and had three or four exchanges with them. But, I never received a satisfactory apology nor anything from the officers themselves. I later saw the officers one evening. They walked away as I was approaching. (laughs)

Id. If 10. TQ, in describing his assertiveness with regard to the police in a situation involving the treatment of a gay youth, explaincd:

I'm certainly not a very timid person and I suspect that I come across quite hard. And I would in a sense be doing that because I've had such an ordeal from the authorities. So when I'm standing there in a sense I'm saying I won't have you do to others what you did to me. Interview with TQ, I 8, in South Africa (Mar.-Apr. 1999) (on file with author).

226. Of course it is important not to underestimate the fact that law is only one thread in a larger system of oppression that influences the views of parents. Perhaps sodomy laws entail two unique aspects in this regard. First, such morally-based laws are popularly thought to represent, or codify, the prevailing views of the community, and are taken by some parents to be an unmistakable statement about the status of their children. See discussion infra note 366 (discussing "folk wisdom" that law represents public morality). Second, some parents might also be overreacting out of fear for their child's well-being; and the law, as far as they understand it, represents part of the threat to homosexuals in society. See Zackie Achmat, Legal Gains Are No Easy Victories, q: The Gayteway to South Africa, at http://www.q.co.za/news/1998/9810/981006-ncgle.htm (Oct. 6, 1998) (stating, after a lower South African court struck down a sodomy law, "[f]ears by parents that their lesbian and gay children could be prosecuted are gone").

227. Interview with JC, 96, in South Africa (July-Aug. 1995) (on file with author). 
healthy skepticism of the association between law and morality. Indeed, individuals who have less experience with the application and interpretation of law may be more likely to view law as representative or reflective of social morahity. Another interviewee explains that her father has "a faith in the law. When it comes to gays and lesbians he says soinething like, 'It's against the law for a reason. Queers just aren't normal people." 228 In a newspaper story about the laws, the director of a gay and lesbian organization explained that "many families rejected their children because they felt that by performing acts of sodony their children were criminals."229

Other parents may imvest the law with authority based not on its supposed instantiation of what is morally right, but rather on its reflection of what the community accepts as proper. In other words, even if law is not imbued with ethical authority, law is understood by many to reflect the values and interests of powerful social groups. Thus, parents of lesbian and gay children unay be concerned about their own standing in the community due in part to the cultural rules and societal norms they perceive to be expressed through the law. ${ }^{230}$ The result is often the same: strong disapproval of their child's sexual identity and, in many mstances, rejection of their child.

In matters involving individuals' self-reflection and reflection through their parents and family, the fact that sodomy laws imvolve criminal sanctions has a special effect. It is not simply the devaluation that lesbians and gays inay feel from the lack of protection under anti-discrimination laws. Under sodomy laws, their sexual relationships are officially illegal, their thoughts considered officially illicit. NC, a social worker who coordinates a lesbian and gay health service center, explained that

[sodomy] laws affect the psychological esteem of many of the clients I have worked with. People feel im conflict with the laws. For many clients, the most important thing that shows they are worth something is the final Constitution. But, for their self-esteem, these continunig anti-gay laws tell them that they are still criminals. ${ }^{231}$

NC's statement is especially significant, because she is describing a state in which the anti-discrimination laws, at least on the books, clearly cover sexual orientation discrimination, yet criminal prohibitions against same-sex behavior remain. The effects of the latter are considerable

228. Interview with DB, ๆ 11, in South Africa (July-Aug. 1995).

229. Charlene Smith, supra note 180.

230. Of course there are other cultural signals that parents are clearly responding to, such as, in the specific ease of JC's father, the influence of Catholicisin. The discussion of law's effects alongside these other social influences is an attempt to identify whether and in what manner sodomy laws are also invoked, and what unique attributes such legal sanctions might possess.

231. Interview with $\mathrm{NC}$, supra note $214, \boldsymbol{7} 3$. 
enough to counter the positive reinforcement provided by the other protections in the law.

\section{Verbal Harassment and Disputes}

Sodomy laws impact people's lives by supporting the hostility and threats posed by individuals outside the family. Many lesbians and gays, for example, have engaged in verbal confrontations with a person who is intolerant of homosexuality and who rhetorically invokes the law. If the dispute is on the subject of sexuality itself, the antagonist may refer to the law as authority to bolster her argument. This type of dispute seems fairly common and unsurprising. ${ }^{232}$ Other disputes, however, are not about sexuality at all (for example, a neighbor's complaint about the level of noise), yet the lesbian or gay individual's status under the law gives the antagonist the opportunity to make a connection to their status and to capitalize on that vulnerability. ${ }^{233}$ In this section, I discuss both types of confrontations. Such interpersonal disputes present one location in which the power of sodomy laws is exercised with indirect but far-reaching results. In these situations, individuals are empowered by the law to carry out verbal ostracism and other aggressions against lesbians and gays. Through these verbal exchanges we can identify ways in which sodomy laws play a vital role in defining social relations and affecting the distribution of social norms.

$\mathrm{AB}$, for example, is a Black gay preacher and political activist who told me about his frequent experiences confronting the law in conversations with others. $A B$ often tries to engage people about their anti-gay views but he keeps bumping up against the law: "I have often had to counter social prejudice that comes from having these laws. In debates with people, especially police, many will say that since 'it's a criminal offense in our country' gays should be treated like garbage."234 Other interviewees reported similar experiences. JC, for example, is a young, successful artist. While at art school, she was confronted on numerous occasions by faculty members who scolded her because she was a lesbian, oftentimes saying to her that it was against the law. ${ }^{235} \mathrm{AC}$, a lesbian woman and a teacher, explained her sense of it: "People use these laws as a point of argument against gays and lesbians. It allows them to think that we are up for

232. See infra text accompanying notes $226-235$.

233. See infra text accompanying notes 236-238.

234. Interview with $A B$, If 7 , in South Africa (July-Aug. 1995) (on file with author). 1 asked interviewees to describe if reference to the laws ever came up in conversations or disputes. Though it occurred several years ago, one interviewee explained that his army doctor

would verbally torment me, thinking he could force or convince me not to be gay. There's one conversation that I particularly remember. On that occasion, he scolded me saying that homosexuality was illegal and that I could be incarcerated or put in jail. He asked how did I feel in an army uniform and told me that I was a disgrace to it.

Interview with BW, supra note $218, \llbracket 6$.

235. Interview with JC, supra note 227 , 19 4-5. 
ridicule. We are often the subject of ridicule, mockery, jokes. It's as though we've given up our rights for the heterosexual community."236

In heated conversation, a rhetorical reference to the criminal status of homosexuality has different effects depending on the situation and personalities involved. Such antagonistic statements may be most disturbing when voiced by government officials or others in authority. ${ }^{237}$ That the laws are not actually enforced is a useless rebuttal. The crux of the other side's position refers to the rule of law as a symbolic marker: a designation of the moral rectitude of lesbian and gay behavior. That sentiment is not denied by the lack of enforcement; the fact that no one is apprehended for committing such an offense does not effectively rebut the notion that the law signifies the acts as condemnable..$^{238}$

Faced with such verbal confrontations, a lesbian or gay person might experience a variety of einotional and psychological reactions. For individuals who wish to view themselves as law-abiding citizens, these rhetorical jabs can cut quite deeply. In some cases, such a verbal assault results in individuals concealing their sexual identity. For instance, $A B$ explained that she does not "coine out" to people if she hears them refer to the law supportively or make hostile remarks related to the law. ${ }^{239}$ It is difficult to ascertain the exact motivation behind individuals' closeting themselves in response to another's invocation of the law. I suspect that, in part, some individuals did not want to be associated with the status of a legal offender. ${ }^{240}$ At the same time, some individuals were perhaps worried about

236. Interview with AC, $\ 11$, in South Africa (July-Aug. 1995) (on file with author).

237. For example, $W J$, in stating that "[t]he laws still have a significant effect on my life," referred to expressions of hatred and prejudice in which people had cited the laws. Interview with WJ, TI 5,8 . He recalled the most recent affront being a statement made by a conservative member of parliament in a meeting with a gay rights organization. Id.

238. A form of this reasoning occurs in Justice Burger's concurring opinion in Bowers $v$. Hardwick. See Bowers v. Hardwick, 478 U.S. 186, 196 (Burger, J., concurring). Justice Burger, in tautological fashion, relies on the Iristory of legal condemnation of same-sex practices to ground his justification for further ethical and legal proscription. Id. The fact that the laws are formally unenforced does not detract significantly from the logic of such reasoning for its proponents, nor diminish the stigma produced by the statement.

239. Interview with $\mathrm{AB}$, supra note $234, \mathbf{9} 73,10$.

240. In describing the more general process of coming out, WJ, for example, explained that knowing about the criminalization of homosexuality "prolonged iny conning out process and my initial acceptance of myself. The laws created an atmosphere for me in which 1 thought that iny identity was abnormal and that my heart-felt emotions were wrongfully unacceptable." WJ, supra note 237, § 3; see also Interview with AP, supra note 218 , $\llbracket 3$. Such personal narratives of one's coming out experience, 1 suspect, still apply in the different stages or instances in which lesbians and gays must balance the costs and benefits of outing themselves, which, as other scholars in the field of sexuality have powerfully described, is a continual iterative process. See Kenji Yoshino, Suspect Symbols: The Literary Argument for Heightened Scrutiny for Gays, 96 CoLum. L. Rev. 1753, 1810 (1996) ("Gays can never be out and be done with it; they must continually reiterate their sexual orientation against a heterosexist presumption that reinstates itself at every pause."); $i d$. at 1810-11 (providing a description of the complex aspects of different gradations and instances of coming out); see also Marc A. Fajer, Can Two Real Men Eat Quiche Together? Storytelling, Gender-Role Sterotypes, and Legal Protection for 
the potential use of the criminal law-the possibility of some involvement of law enforcement or the criminal justice system due to the law's enforceability. ${ }^{241}$ Whatever the precise reason, faced with the threatening message inherent in statements favoring criminal punishment for homosexuality, many lesbians and gays respond by concealing themselves and sometimes gay bashing others. RF expressed a sense of his own collaboration:

The laws have come up in discussions that I have been in with people. People's response has been both positive and negative. The negative say some very hurtful things like "It's right for those fucking moffies!'242 If you are closeted you usually allow them to say these things. You deny friends and, worse, may even make negative comments yourself for fear of being discovered. ${ }^{243}$

So far, the experiences described in this section have involved occasions in which the subject of a verbal confrontation bears directly on the evaluation of a person's sexual identity. Sodomy laws, however, are also invoked in confrontations that do not directly relate to a person's homosexuality. In disputes about seemingly unrelated matters, a person's sexual orientation and, consequently, their position in relation to the law may be brought into account.

Two common sites of such disempowerment are the home and local neighborhood. To understand the social dynamics that operate in such disputes, it may be useful to consider an analogy to the "free market." In the regular scheme of things, verbal disputes between neighbors take place in a sort of free market: an open competition or contest between individuals with differing preferences. When heated disagreements arise, individuals may assail one another through invectives, threats, or other verbal attacks. Government plays no apparent role in these matters. Yet this conception of private disputes is vulnerable to the same critique that has been leveled against the classical free market model: the market is never truly free because the state necessarily affects background rules which influence who wins and who loses. ${ }^{244}$

Lesbians and Gay Men, 46 U. MIAMI L. Rev. 511 , 595 (1992) ("Even for those of us who choose to be completely open about our sexual orientation, the choice to hide constantly recurs. Each time gay men and lesbians meet a new person or interact with a new group of people, we must decide whether to come out yet again.").

241. See, e.g., Interview with BN, 997 8-9, in South Africa (July-Aug. 1995) (on file with author).

242. "Moffie" is a pejorative term for lesbians and gays; the etymology of the word is unclear. Interestingly, like the word "faggot" in the United States, lesbian and gay liberationists attempted to coopt the term and use it in an affirmative manner, but they met with little success. Shawn de Waal, Etymological Note: On "Moffie," in Defiant Desire, supra note 135, at $\mathrm{x}$.

243. Interview with RF, supra note 216, $q 4$.

244. See, e.g., Duncan Kennedy, Cost-Benefit Analysis of Entitlement Problems: A Critique, 33 STAN. L. Rev. 387 (1981) (arguing that existing distribution of legal entitlements and unavoidable allocation of baselines affeets bargaining behavior and final outcomes in liberal law and economics models). 
In the context of this study, the state, through the adoption of sodomy laws, helps structure the nature and influence the outcome of certain disputes. A lesbian or gay individual is at a distinct disadvantage vis-à-vis heterosexual actors because of the background rules that define his or her sociopolitical position within the community, and because of the potential for enforceinent of laws against him or her. ${ }^{245}$ A hostile neighbor may introduce the specter of the state's criminal enforcement apparatus by threatening to invite police intervention on her behalf. Such invocations of the law might also be made more subtly. The state is arguably always latently present in these settings, favoring one group of actors over another. In short, the legal position the state adopts concerning the criminal status of lesbians and gays helps set the ground rules within which the "marketplace" of competing actors operate.

A specific example of a neighbor's invocation of the law illustrates the point. Recall that one provision of South Africa's sodomy statutes specifically prohibits erotic gratification in the context of three "men at a party, "246 and consider the following altercation:

On one occasion, I was at a friend's party with several gay people and the neighbor threatened to close down our function. We were sitting outside the friend's house in Rustok. His next door neighbors were Muslim and it was their day of fasting. They said they were disturbed by the noise. But it wasn't just that we were having soine people together, but because we were gay. The neighbor specifically said, "You moffies are making a noise" and threatened to shut us down. ${ }^{247}$

This episode illustrates the force of sodomy laws in "private" disputes. The neighbor's pejorative statement about the sexual orientation of the guests combined with her threat to shut down their gathering ushers the specter of state power to the fore. In open argument, naming the other person "moffie" and threatening to summon law enforcement to control his behavior is bolstered by the state's position on such matters. The neighbor

245. One of the unanticipated findings of this study was the level of concern many individuals had about the possibility of police involvement when, as a general matter, these laws are unenforced. One possible explanation is that the information on non-enforcement is unknown to (or not trusted by) these individuals. Another possible explanation, and a likely one, is that despite the lack of actual enforcement, sodomy laws retain the potential for enforcement and the threat of their use weighs heavily on individuals' minds in various romantic settings. Regardless of how reasonable it might be to rely on the assurance that a prosecution or arrest for sodomy will not happen, people may be frightened by its prospect, and especially concemed if they believe it is a police officer's duty, and sometimes penchant, to apply anti-gay laws in certain situations.

246. See supra text accompanying notes 165 .

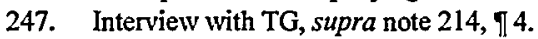


aligns herself with prevailing state powers, buttressed by the existing criminal statutes. ${ }^{248}$

In some disputes, the state may more clearly manifest itself through the actual presence of police. Take for example the account of HR, a lesbian woman living in the western cape. She described a history of problems with her neighbors, including difficulties that had already made her concerned for her safety, even in her own home. ${ }^{249}$ In one incident that was memorable to her, she and her partner were having an argument while standing outside their house. "The lady living at my neighbor (sic) was standing outside as well and a police car coincidentally drove by. She called to the police saying ' $Y a h$, they're fighting. Lot of bloody lesbians in the house." HR and her partner ceased immediately as they saw themselves in the reflective gaze of the police car. The car stopped for a while, then finally drove off. 250

This encounter with the police, and the neighbor's willingness to summon the officers, illuminates the threat that some feel when police are not immediately present but can be called to the scene. HR's having ceased immediately shows how the state's direct presence can control her and her partner's every move. The law's involvement in a seemingly "one time" incident, however, can also influence individuals' actions beyond that occasion. The experience for those who live it and for others who are told about it counsels future restraint. Many lesbians and gays learn to monitor their volume, close their curtains, discipline their emotional gestures, and adopt other devices to keep their private lives out of neighbors' sight. HR reports that she has decided to still hold get-togethers with lesbian friends, despite the difficulties with her neighbors. She speaks in terms of luckiness that she has thus far avoided any further repercussions. ${ }^{251}$

The problems of living close to neighbors, such as in an apartment complex, was first made apparent to me by BW. BW lives in an apartment complex where each unit has a small garden visible to two or three other units, all of which share the same wooden fence. He explained how the laws threaten his social life, even in his home: "I have often wanted to have nice parties with lesbian and gay friends. But, I am very wary of

248. I should make one thing clear, lest my perspective on the incident is misunderstood. I do not necessarily agree with the interviewee's suggestion that the neighbor would have tolerated the noise if the partygoers were not gay. In fact, I am skeptical of such an assessment given the neighbor may simply have wanted peace and quiet on her religious holiday. The point is simply that the neighbor, seemingly annoyed by the disturbance and wanting to close down the party, was strengthened in her ability to control the situation by the gay men's relationship to the law. Her reference to their sexual orientation and connecting it to an invocation of law enforcement yielded power she would otherwise not possess without the background presence of the criminalization of homosexuality.

249. Interview with HR, qๆ 3,7, in South Africa (Mar.-Apr. 1999) (on file with author).

250. Id. $₫ 4$.

251. Id. $\llbracket 5$. 
neighbors getting upset and authorities being called in. 1 now live in an apartment complex which makes matters of privacy much worse."252

\section{Residential Zones and Migration}

Because of the potential threat from individuals in their surrounding community, many lesbians and gays try to live in areas that provide them with a significant degree of privacy and security. Having a choice of where to live of course depends on one's financial resources. So, this is another matter in which socioeconomic status affects the level and type of injuries that occur. Also, black South Africans, due to the legacy of apartheid, are likely to suffer disproportionately from deprivations that vary according to socioeconomic status. In fact, many black lesbian and gay South Africans still live in townships. ${ }^{253} \mathrm{lt}$ is generally difficult, if not impossible, for these individuals to devote limited financial resources to moving out of these areas; and the areas themselves compound some of the problems already discussed. Poorer residential areas, especially townships, are densely populated and thus many of the problems that lesbians and gays face with neighbors and local communities are exacerbated there.

Where a lesbian or gay person lives can play a very significant role in their overall sense of security. TG is a thirty-seven year old black man living in New Brighton township on the country's west coast. With a veteran's knowledge of South African lesbian and gay history, he relayed to me the current cartography of dangerous areas:

There are many areas of South Africa that are especially hostile. Bloemfontein, Pretoria, and Beaufort West are the worst. You cannot walk hand-in-hand or you'll be called a sinner, given names, called things like "worse than the devil." I know of people

252. Interview with BW, supra note $218, \mathbb{1} 16$.

253. The apartheid government provided for townships to develop on the outskirts of major cities because blacks were necessary to help run the economy but were prohibited from living in white urban areas without special permits. See Christopher A. Ford, Challenges and Dilemmas of Racial and Ethnic Identity in American and Post-Apartheid South African Affirmative Action, 43 UCLA L. REv. 1953 (1996). Ford explains that townships

are the African living areas that were permitted to spring up in loose constellations around the country's major centers of employment during the apartheid years .... For the most part, squalid commuter settlements housed Africans forced to travel sometimes for hours daily on public transportation to areas where they worked.

Id. at 1962 . When racial residential restrictions were lifted, in part in 1986 and in full in 1991, blacks were still unable to move into the cities primarily because of enormous financial barriers. FED. Research Div., Library of Cong., SOUth Africa: A Country Study 186 (Rita M. Bymes ed., 3d ed. 1997) ('In 1986 the government called for 'orderly urbanization,' under which a limited number of blacks could live in officially 'white' urban areas, as long as housing was available. Few black workers could afford to take advantage of this policy, however, and demographic trends did not change noticeably."); $i d$. at 188 (noting same lack of demographic change after major residential segregation laws were lifted in 1991). To this day, townships are mostly densely populated, sprawling areas, extremely impoverished and often lacking basic infrastructure. See, e.g., Joshua Raboroko, "The Dark City" In A Severe State Of Decay, The Sowetan, Apr. 18, 2000, 2000 WL 20069684. 
around Cape Town who've had to move from small towns to bigger cities because of really hostile communities. ${ }^{254}$

TG's account accords with the stories of other interviewees. If one has the luxury of being able to choose, the preferred areas to live and places to travel are often determined by the factor of local prejudice. The fact that many lesbians and gays who can afford to relocate do relocate reveals the gravity of these concerns. IT provides an illustrative example. IT has had many privileges in South African society; he is forty-seven years old, a middle-class professional, and white. His personal experiences indicate that he has a range of choices available, which, although limited by anti-gay local prejudices, are broadened by his race, gender, and class status:

I could not live in a suburban environment. Instead, I know I must live in more cosmopolitan areas, which tend to de-emphasize the concern for nuclear family arrangements. It is also difficult to select places to travel. Resorts and packaged tours mostly cater to straight couples in a way in which my presence may easily be objected to. ${ }^{255}$

The previous accounts of poor neighborhood and community relations indicate why people like IT would need to analyze such situations so carefully. The fact that these areas are so closely scrutinized also indicates the nature of the threat posed by neighbors and members of the community in their ability to leverage the law against lesbian and gay residents. In terms of broader residential factors, for some lesbian and gay foreign nationals living in South Africa, the prospect of sodomy law's decrimmalization along with other positive developments in gay civil rights, figured prominently in their decision to migrate to South Africa. ${ }^{256}$

\section{Restricted Public Places}

Perhaps every romantic couple with plans to go out for the night hopes the evening will run smoothly. For same-sex couples, such occasions may be riddled with dangers and fear. Interviewees explained how they consider the risk of encountering trouble from strangers and the prospect of involvement with the police. Their statements reveal precautionary measures, or a sense of vulnerability, based on the potential for sporadic enforcement of the laws. For example, PC stated:

I think I've been very lucky being a gay man who hasn't had direct encounters with the police over these laws. I suppose I haven't

254. Interview with TG, supra note 214, ๆ 3.

255. Interview with IT, ๆ 9, in South Africa (July-Aug. 1995) (on file with author).

256. CM explained that his decision to migrate from Zimbabwe to South Africa was principally due to the difference in anti-gay laws. See Interview with CM, II 9, in South Africa (July-Aug. 1995). Also, IT, a gay anti-apartheid activist who had returned from exile explained, "l would not have come back if 1 did not have word that South Africa was destined to change its domestic sexual orientation laws." Interview with IT, supra note 255 , ๆ 5. 
particularly provoked attention. I am very selective, for mstance, in which restaurant to go to on a date. I would not go to a "family" restaurant and I'm deliberately discreet in selecting a dark place or an establishment that is known for being hospitable towards homosexual couples. ${ }^{257}$

PC's account is troubling. He is in his late forties; yet when going out with his partner, he reports that he is "deliberately discreet in selecting a dark place." He routinely seeks personal safety by trying to evade the sight of the general public. Foucault's analysis of the Panopticon helps explain this account. ${ }^{258}$ The mechanism of illumination under a watchful gaze creates a particularly effective means of behavior control: "Full lighting and the eye of the supervisor capture better than darkness, which ultimately protected. Visibility is a trap.".259

While a heterosexual couple might experience some frustration thinking about where to spend the evening, many lesbian and gay couples routinely consider more serious issues of safety. ${ }^{260} \mathrm{JC}$, a twenty-five year old lesbian woman, fears that her being seen with her partner might risk her partner's job: "We also generally try to choose gay and lesbian places and seek out safe areas. This secrecy is psychological violence, which I find outrageous that it still exists in this country. I think of these secretive strategies as a sort of survival techmique."261

hidividuals report that relating to the surrounding world in such a tactical manner affects who they are. Some people are not adept at this sort of strategic thinking, and some just find it unpalatable. This practice of analyzing situations can feel like one is shaping one's mind to think like a strategist or conspirator. The world as a lesbian or gay couple is generally mapped according to safe areas, zones of vuhierability, and sites of public exposure. These various fields constrain where one goes, how one acts, and how secure one can ever feel. Calculation and living within these constraints may becoine second nature.

There are many who are determined to resist having their lives circumscribed by such social prejudices and legal hazards. Yet, as also explained above, resistance itself defines one's sense of self and place in society. It may also prove difficult to succeed, that is, to refrain from being constantly aware of the gaze and the imminence of legal and social sanctions. One interviewee stated:

257. Interview with PC, $\{$ T $4-5,6$, in South Africa (July-Aug. 1995) (on file with author).

258. See supra discussion at text accoinpanying notes 208-213.

259. Foucault, supra note 208, at 200.

260. For example, one gay man reported:

My partner and I are limited in the places we know we can go for entertainment.... We

choose only those places where we know we will not be harassed . . . For example. it's best

to go to a place where we know the owner is gay.

Interview with NK, ๆ 8, in South Africa (July-Aug. 1995) (on file with author).

261. Interview with JC, supra note $227, \mathbb{1 0 .}$ 
I have not let laws and social prejudices stand in the way of where I go on a date.... I am always ready to deal with an adverse reaction, but have not yet directly encountered it. This does not mean that it is not a recurring issue. ${ }^{262}$

\section{Restricted Movement and Gestures}

The Panopticon was considered an especially effective tool because it held the promise of producing the desired behavior by inducing the subject to regulate herself, to "become[] the principle of [her] own subjection."263 Under the eye of an eternal gaze, the inmate would rationally conduct herself-body and mind-in accord with the prescribed rules. Although she could hope the guards were not watching at a given moment (they could see her, but she couldn't see them), the extent of the penalties involved and the risk of being wrong led to a rational response: conformity with the expected modes of behavior. This disciplinary technique thus efficiently produced subordination through internalization of prevailing rules and expectations.

When lesbian and gay people move through public spaces under the eye of a social gaze, they must also consider the implications of visibly deviating from prescribed norms. To be sure, social sanctions play a role, but the accounts of many lesbians and gays indicate that the laws have a direct bearing on how they behave. ${ }^{264}$ One possible reason for sodomy statutes having such a powerful effect is the interpretation laypersons may give to the laws. The various interpretations people have of the law, in turn, produce different attitudinal and behavioral responses.

One factor influencing a person's understanding of the law is whether he or she is connected to someone with specialized knowledge of the law, for example, a friend who is an attorney. Among those individuals who do not have such a link or contact, many may think that simple public displays of affection violate the statutes. ${ }^{255}$ Others, on the other hand, fear the expansive interpretation that police, prosecutors, and judges might give to conspicuous public gestures. ${ }^{266}$ Still others believe that while such public acts are not strictly prohibited, overt displays of affection subject such actors to increased suspicion and surveillance by the local police and com-

262. Interview with IT, supra note 255, , 13.

263. FoucauLT, supra note 208 , at 203.

264. See infra text accompanying notes $272-275$.

265. $A C$ is a teacher in her mid-twenties. She explained that she is generally unfamiliar with the laws, but she thought "it's possible to be arrested for just holding hands." Interview with AC, supra note 236, , 8 .

266. See, e.g., Interview with $\mathrm{DB}$, supra note $228, \uparrow 2$ ("I know those laws are not as applicable to lesbians. But, besides my fear and my concern for gay male friends, I think that officials may find some way or another to apply certain laws against me."). 
munity. ${ }^{267}$ Other individuals who have greater familiarity with the literal text of the statutes may take seriously the consequences that are contained in the statute, ${ }^{268}$ such as the prospect of two-years' imprisonment ${ }^{269}$ or the ability of members of the public to make a citizen's arrest. ${ }^{270}$ Based on these multiple interpretations and responses to the law, it is apparent that the inherent vagueness of sodomy laws creates confusion and heightened concerns. As a leading South African jurist explained: "The problem is that no one knows what other male-male sex acts (like kissing or fondling) could conceivably still be held criminal."271 The sodomy laws' unsettling ambiguities, such as the definitional scope of an "unnatural offence" and the risk of being wrong often induce practiced self-restraint.

Indeed, from this mix of various understandings of the law, a common response often results: self-regulation of one's physical acts while in the eye of the public, especially when in the vicinity of law enforcement authorities. The following account by AC illustrates the extent of such selfmonitoring:

In 1993, I was in my first serious lesbian relationship. This was in many ways my induction to the "gay scene." The woman I was with was paranoid about our being detected by authorities. I had the sense that even though we loved each other we could possibly get "caught" for doing something wrong. We had to be sure to be discreet except in safe areas. ... If we walked by the police, she would say, "Take your hand off my leg. Let's not look. Just try to appear like straight friends." I immediately thought to a certain limited point as to how affectionate I could ever be, which I began to hate. As much as I liked this relationship, I couldn't bear this pressure. $^{272}$

AC's story is notable for its suggestion of an initiation rite im becoming a lesbian couple in public spaces. The effect of police officers' presence, including being on the lookout for them, illustrates the connection between public conformity and the legal realm. It is impossible to explain AC's story as simply a response to social sanctions. When moving in public, her physical comfort and measured behaviors stand and fall not at the sight of

267. See, e.g., Interview with HR, supra note 249, I 2 ("I do not agree with the homosexuality laws. They force everything we do to be closeted like walking on the street with your lover, kissing a lover on the street, or holding hands."); Interview with MG, \{f 4-5, in South Africa (July-Aug. 1995) (on file with author); Interview with BN, supra note 241, ๆ 9.

268. See, e.g., Interview with GD, supra note 225 , $\llbracket 2$.

I know a lot about the anti-gay laws since my lover is an attorney and we have had long discussions relating to the particularities of the law. I know that a majority of gay sexual acts are illegal. A couple are heavily illegal, such as sodomy, which you can legally be shot for. Id.

269. Sexual Offences Act $23, \S 22$ (g) (1957).

270. Criminal Procedure Act \$ 51 (1977).

271. Cameron, supra note 152, at 91.

272. Interview with $A C$, supra note 236 , I 10. 
other citizens as much as at the sight of police officials. The law then, rather than generalized homophobia, has a umique place in the regulation of her behaviors and her relationship to public space.

While AC describes her fear in relation to the police, other state officials may raise similar concerns. Police officers admittedly represent special threats and more direct extensions of the government's force throughout the social space. Other government officials, however, may also place lesbians and gays on a heightened state of alert. One individual explains, "I am therefore also very cautious of people in authority at state facilities, like sports parks. I know these people are one step away from the police."273

The measures couples adopt to avoid detection can have collateral impacts on other interactions they have with one another, and ultimately the definition and strength of their relationship. The regulation of physical gestures may preclude individuals, for example, from providing comfort in times of stress or from showing spontaneous affection in moments of joy. These constraints can also affect the way partners act towards each other when in private. Such an outcome may occur imperceptibly or, as the following account from $\mathrm{MG}$ shows, quite consciously:

We are never romantic when seeing each other for the first time in the day like when $l$ pick him up at work. When we walk along the beach front, we try to show no emotion. This constantly being on guard so as not to make even a sudden touch, puts a strain on our relationship. You just cannot let your guard down ... But, as anyone in a loving relationship knows, a slight touch can make all the difference. A comforting gesture can really help on a bad day or for simple tenderness. ${ }^{274}$

These accounts indicate the ways people adjust their expectations and personal behavior due to the legal regime's interaction with the social field and public spaces. For many people, the laws themselves create the sense of surveillance. One person explained, "I think even after the laws are scrapped there will be a lot of this still ingrained .... Even though I don't have any special knowledge about the laws, the general feel of it is enough. It's like a mother watching over a child."275 The eternal gaze that Foucault described was built on similar principles. In this context, sodomy laws not only help create and target lesbians and gays as criminal wrongdoers; they also help subject those individuals to an abiding sense of their place and movements within the impersonal public realm.

273. Interview with IT, supra note $255,916$.

274. Interview with MG, supra note 267, If 5. Notably, MG's partner works for the government within the criminal justice system. MG cited this as a reason they were particularly concerned about being "caught." Id. \4.

275. Interview with WJ, supra note $237,9\{18,23$. 


\section{7. "Safe" Places}

Insofar as the law's intersection with public surveillance of homosexuality creates dangerous and off-limited places for lesbians and gays, it also produces areas that offer relative security. The problems that lesbians and gays encounter in public space generate a need for gay-centered venues that can escape the encompassing public gaze. ${ }^{276}$ Gay bars and clubs are the emblematic safe havens for lesbians and gays to socialize openly, relatively free from those concerns. Yet, even the boundaries surrounding these safer locations and the environment within thein present significant threats. Going to a gay bar or club involves hazards that are produced in part by the criminal law's regulation of homosexuality.

Popular gay bars in the major cities are generally located in dark and remote areas of town, and usually in places with a limited police presence. ${ }^{277}$ The fact that these bars operate on the margin of the regular protections of law enforcement presents particular problems, most notably that of gay-bashing. A number of my interviewees discussed physical assaults that either they or soineone they knew suffered, most of which occurred directly outside a gay bar. ${ }^{278}$ Local thugs know that gay bars are the surest places to find lesbians and gays, and the pronounced lack of a police presence around these areas makes for especially vulnerable targets. Individuals are often assaulted after exiting a bar, and sometimes an assailant meets his victim inside the bar and then lures him outside to be ambushed.

In a number of ways, the laws against hoinosexuality play a part in producing this social reality. As other scholars have elaborated more fully, the criminalization of hoinosexuality helps generate anti-gay hate crimes. ${ }^{279}$ That is, the criminal laws support the attackers' inspiration to punish homosexuality with violence. Furthermore, the fact that these physical assaults often occur at gay bars is also produced, in part, by the background presence of the laws. The law's role in regulating public space through visibility and surveillance encourages these establishments to operate under conditions that effectively leave patrons more vuInerable to assault. Finally, the fractured relationship between the gay commumity and the police, created in significant part by the criminal laws against homosexuality, ${ }^{280}$ also means that the assailants operate under conditions of unique impunity.

276. Cf. Gevisser, supra note 165 , at 37 (explaining that because the authorities attempted to monitor homosexuality in public places instead of trying to uncover and wipe it out, "[ $t$ ]he "effect was to move the subculture indoors, into bars and clubs").

277. Interview with DB, ๆ 4 ("'G] ay bars and taverns have to operate in out-of-sight, seedy places. All gay clubs in Port Elizabeth are down dark streets and unsafe arcas."); Interview with BW, supra note $218, \mathbb{1 7} 17$ ("Those places are often in the seediest parts.").

278. See, e.g., Interview with BW, supra note 218 , ๆ 17; Interview with SS, ๆ 7, in South Africa (July-Aug. 1995) (on file with author); Interview with TR, Ffl 5-6, in South Africa (July-Aug. 1995) (on file with author).

279. See supra text accompanying notes 73-82, 102-104.

280. See infra Part III.A.9. 
Individual victims do not feel the impact of these assaults alone. Many of my interviewees, though not the victims of such crimes, knew of friends or others who had been. ${ }^{281}$ This knowledge created a sense of their own vulnerability and affected their understanding of self and their relationship to the larger community, leading some to conclude that not even gay bars were safe. Many of the interviewees who had not been the victim of assault used terms such as "lucky" to describe themselves, implicitly underscormg their general sense of the hostility and dangers that confront their lives and their vulnerable place in society. ${ }^{282}$

Inside the bars themselves, other dangers exist. A number of interviewees had been, or knew of someone who was, blackmailed by a person they met at a bar who was either a police officer or posed as one. ${ }^{283}$ The victim had engaged in one stage or another of proposing, agreeing to, or engaging in sexual relations, when the other person stated he was an undercover officer. The officer, or imposter, then threatened the victim with taking him to the police station if he refused to pay money or, in some cases, perform sexual "favors." Cape Town, in particular, appears to have a significant number of stories of police officers, sometimes plain-clothed and other times not, leaving with a gay male patron and then threatening to arrest the individual if he did not perform oral sex. ${ }^{284}$ The fact that these stories also travel by word of mouth means that many individuals are apprehensive or frightened when meeting someone at a bar or simply going to a bar with friends.

\section{The Intersection of Race}

Post-apartheid South Africa is still troubled by the vestiges of structural racism. For black lesbian and gay South Africans, the intersection of sodomy laws with racial discrimination causes added and unique hardships. Most urban blacks still live in townships: densely populated areas which offer scant, if any, gay-friendly social resources. ${ }^{285}$ Financial constraints mean that many young adults have to live at home with their parents. These close living quarters create additional problems in lesbian and gay individuals' personal lives and in their relations with the community. Once a

281. See, e.g., Interview with BW, supra note 218 , ๆ 17 ("I do not go to gay bars or clubs because I worry I could be assaulted. ... Although I've never been attacked, I have heard of people being assaulted ...."); Interview with CM, supra note 256, I 9 ("It's even difficult to go to gay bars. I know people have often been assaulted outside gay clubs."); Interview with TR, supra note 278, I 5 (describing an incident she recalled of a gay man outside a local bar who was attacked by a group of people and "stabbed an inch above the lung and aIso in the shoulder").

282. See, e.g., AA, If 5 ("I've been really lucky that nothing like that has happened to me."); Interview with MG, supra note 267, \ 2 .

283. See, e.g., NK, If 6 in South Africa (July-Aug. 1995); RF, II 7 in South Africa (July-Aug. 1995).

284. See, e.g., NK, ๆ 6 .

285. See supra note 253 (describing general conditions of townships). 
person is known for doing something wrong in this "small town atmosphere," an unshakable label attaches and, especially if such matters involve the law, he or she may become particularly vulnerable to abuse by the police. BN explains his relationship to the police in this community structure: "I'm very careful not to hold hands or kiss my lover in public. It's like the police can smell gays, like it was a part of their training. ... [I]n black communities ... gays are singled out as 'moffies' and never forgotten."286

Outside of the townships, race also plays a significant intersecting role in black lesbian and gay couples' lives. Social locations within the city center (places people go to relax, to meet others, or to find entertainment) are limited for blacks and, in certain areas, are fraught with danger. Gay bars are usually located in urban areas, where most blacks do not live due to persistent social and economic effects of apartheid's residential zoning laws. ${ }^{287}$ Interviewees explained that they wanted to go to gay clubs as a place of freedom and recreation. However, they faced difficulties because of the distance, financial costs, and informal racial discrimination of club owners. As a number of interviewees explained, although some clubs were called "integrated," in practice, this meant the social mixing of Asians and whites; blacks were given implicit, and sometimes explicit, messages that they were not welcome. ${ }^{288}$ Thus the social spaces and zones of protection available to black lesbian and gay individuals are significantly more limited than for their white and Asian counterparts. ${ }^{289}$

Conditions of racial discrimination also intersect with sexual orientation in suburban coinmunities and urban public spaces. Interracial couples, for example, are more likely than white couples to encounter the problems described above in the context of neighborhood animosity and problems with the police. JC explained that "it's difficult for two lesbian lovers to live together.... [W] have to be somewhat secretive with so many people.... [T] wo white people living together is not really as much of a

286. Interview with BN, supra note 241, \ 6 .

287. As discussed above, see supra note 253 , these apartheid-era laws prohibited blacks from living, though not fron working, in city centers. Today, many black communities are still located far from the city center, and tens of thousands of people still have to travel long distances to work and shop. It will take several years before migration patterns and economic advancement can overcoine the aftereffects of these zoning laws.

288. Interview with NC, supra note 214, I 11 ; Interview with TR, supra note 278 , ๆf 7-8. Interestingly, TR explained that in her experience, bars can try to maintain a racially exclusive, rather than inclusive, atmosphere by the genre of music the bar plays and the type of dress code it enforces. Id. $\lceil 8$.

289. Once a bar earns a reputation for being discriminatory, blacks may stay away for a long time. In one instance, several people held a public protest against a popular bar for its attempt to exclude blacks. The protesters succceded im having the bar owner institute reforms, but the effect of the original discrimination caused many blacks to stay away due to the feeling they were never genuinely welcome. See Interview with NC, supra note 214, \11; Interview with TR, supra note 278, Tf 9-10. 
problem, but as a mixed couple we invited greater suspicion."290 Lesbian and gay people involved in an interracial relationship also reported increased suspicion when they walked with their significant other im public. This factor accentuates many of the adversities described above. For many black lesbians and gays, their relationship to the police in the city center was already strained due to racism im the police force. A black person's being outwardly lesbian or gay often put him or her at special risk of becoming a target or singled out by racist white cops.

\section{Relation to Law Enforcement in General}

Perhaps the most dramatic and long-lasting effect of sodoiny laws is the fractured relationship many people have to the law and to the police force in general. Some people make a conscious connection between the sodomy laws and their antagonism toward the police. Many lesbians and gays believe that they have something to fear from police officers because of their status under the law. In times of trouble, this may result in their not reporting crimes committed against them, one effect of which is even further alienation from regular patterns of law and order. ${ }^{291}$ Others have a poor relationship to the police but do not consciously connect this fact to the anti-gay laws.

The police mandate of community protection and crime prevention is a threatening message for people who are supposedly a danger to public order or to public morality. Standing outside the law, many lesbians and gays are apprehensive of the police. BW explained his attitude: " 1 am fearful of the police. As a gay man in South Africa, it's like a feeling of someone being out to get you. They think 'we have to rid society of you.' Some of the police are also good people who are only trying to apply the law. But still, 1 mostly keep to myself ...."292 It does appear that many officers have an antagonistic view of lesbians and gays in part because those individuals' sexual conduct is illicit. ${ }^{293}$ Regardless of the extent to

290. Interview with JC, supra note 227, q 8.

29I. In South Africa, where the police force has been connected to the enforcement of a racist regime, the discrete social effects produced by sodomy laws are difficult to decouple from this historic relationship. Notably, however, many white lesbians and gays who otherwise had little to fear from the police, especially if they were not politically active in the anti-apartheid struggle, were alienated from the police because of the anti-gay laws. The interviews I conducted also focused on the post-apartheid period, and thus the interviewees' accounts suggested a relationship between the police and the sodomy laws that existed apart from the role the police played in the racist regime.

292. Interview with BW, supra note 218 , If I9; see also Interview with SS, supra note 278 , If 11 ("I feel very negative about the police, even witb the changeover in government. There are still the same faces on the police force. The state is still carrying on anti-gay legislation."). In a similar state of mind, WJ, a gay law professor, stated: "These laws against gays and Iesbians contribute to my lack of confidence in the police force as impartial ... I regard them as violent thugs." WJ, supra note 237, q.91 6,8 .

293. For example, IMG, a gay psychotherapist who 1 interviewed, has had hundreds of gay patients and numerous encounters with the police on patients' behalf. On several occasions, he has 
which this is true, it is a widespread perception within the lesbian and gay community, ${ }^{294}$ and significant consequences flow from that perception.

Several interviewees reported that, on one or more occasions, they did not turn to the police for help when they were the victim of a crime. This was especially likely to be the case in situations directly related to their sexual orientation. ${ }^{295}$ For example, a sixteen-year-old lesbian girl was raped by her brother-in-law who said he did it "to make a woman" out of her. She did not report the rape because explaining what happened would have involved comming out to the police. ${ }^{296}$

A significant number of those who refuse to report crimes committed against them are male sex workers. This failure to report occurs especially when the assailant was the sex worker's client. ${ }^{297}$ Although the person could possibly report the crime but omit the fact that they were engaged in sex for hire, if it is likely that they will at least have to explain that they were in a sexual relationship with the assailant, many are not willing to go to the police. "Chris" is a sixteen-year-old runaway who turned to sex work to make a living. He earned enough money to register for technical college and moved in with his boyfriend "David" to share costs. One of David's former clients becaine "insanely jealous." 298 The man physically threatened Chris and, to prove his point, cut off Chris's baby finger. SS, the social worker who told ine about Chris's story, took him to the hospital. Chris wanted to lay charges but felt that was impossible. As SS explained, "[t]he laws against sex work, age of consent, and gay sex all combined to leave Chris in a vuhierable state."299 Chris needed his parents' consent to bring a suit. And, if he went directly to the police, he would have to explain the circumstances that surrounded the assault. Even if he could omit the commercial nature of the relationship, he would have to explain that he

assisted gay male clients who were raped or physically abused. In his experience, police officers disregard or discount these types of cases due to both a sense that the victim involved himself in illicit activity and the stigma associated with gay sex. Interview with IMG, TfI 6-9, in South Africa (July-Aug. 1995) (on file with author).

294. See, e.g., GD, supra note 225, \21; WJ, supra note 237, \{โ 6, 8.

295. See, e.g., Interview with TG, supra note 214, ๆ 7 ("Some of my close friends have been in situations where they were either abused or raped....I had a friend who was recently raped and stabbed in the back. None of them ever went to the police.").

296. Interview with NC, supra note 214, ๆ 8 .

297. The illegality of prostitution is an obviously confounding variable in trying to determine the degree to which the criminalization of homosexuality affects the failure to report. Notably, in an ethnographic study of fifty male prostitutes, Donald West reports that the these individuals have a "low expectation of obtaining help or redress if they approach authorities." Donald J. West, Male Prostitution 113 (1993). In another part of the study, West states: "Their attitudes displayed a pervasive hatred of police, sometimes based on contacts in connection with offences unrelated to prostitution. Their most vociferous complaints, however, arose from a perception of police as antagonistic and prejudiced and prepared to misuse their powers to harass gay men." Id. at 287.

298. Interview with SS, supra note $278, \uparrow 4$.

299. Id. ๆ 6 . 
was in a sexual relationship with the man and he did not want to place himself at risk with the police. ${ }^{300}$

In various other situations, individuals do not report crimes committed against them that are "gay-related" for fear of the laws. Some interviewees explained that they, or someone they knew, felt unable to report crimes, such as violence or theft, committed by a sexual partner if it meant having to explain to the police the related incident or surrounding circumstances. ${ }^{301} \mathrm{MN}$, a woman in her twenties from a large township, explained: "We can be beaten up, but have nowhere to turn. In 1995, 1 was violently attacked by my partner. ... She stuck a knife to my throat. 1 knew 1 couldn't report this to the police. They would ask what I was doing with another woman." ${ }^{302}$ Similarly, OR told of an incident in which his partner had physically assaulted him including stabbing him with a knife. "I went to get help from the police, but when I got there, I decided not to go into the police station," he explained, "[h]ow could I tell the police what happened, that we were a gay couple?" ${ }^{303}$ Another interviewee's account suggested that failure to report such crimes was one of the problems she viewed as persisting despite the new constitutional promises for lesbians and gays: "Some of my close friends have been in situations where they were either abused or raped... None of them ever went to the police. They were too afraid to. That still needs to change." ${ }^{304}$

One of the effects that appears to result from these situations is the anticipation that a sexual partner might take advantage of this underlying vulnerability in relation to the law. PC explained: " 1 know that a sexual partner can steal from me or commit some other crime knowing that I'll have trouble reporting to the police. This hasn't yet happened, but it has always been in the back of my mind." 305 PC paused, thinking about something, and then added, "In actuality, I would probably report it if something did happen." ${ }^{306}$ One problem for PC, of course, is that even if he would in actuality report the crime, a potential wrongdoer might not consider that fact beforehand. The situation leaves PC susceptible to attack and having to worry about such matters vis-à-vis the very people with whom he would otherwise let his guard down. Interestingly, those individuals have the same reason to worry about PC. For example, BW, whom PC does not

\footnotetext{
300. Id. 9 9वा 4-6.

301. See $\mathrm{TG}$, ๆ 7; $\mathrm{AB}$, ๆๆ 9-10. $\mathrm{AB}$, qโ 8-10; $\mathrm{BN}$, ๆ 8.

302. MN, ๆ 6; see also BN, ๆ 8 ("It's especially difficult for a gay person to report being assaulted by someone. The police think it's a laughing joke.... 1 am afraid to go to the police station to report anything since 1 know there is a great chance they will lock me up instead.").

303. OR, I 6. OR also spoke about another incident in which he was robbed by a sexual partner and felt he could not report it to the police. Id. If 5 .

304. TG, ๆ 7; MG told of a man he knew who had been raped who, as MG described it, "has had to live with this trauma all these years and never sought assistance." MG, ๆ 8.
}

305. PC, ๆ 7; see also IT, ๆ 14.

306. PC, ๆ 7 . 
know, but who lives in the same town, stated, "I know not to ever take a person home who I may meet. I could be attacked or robbed." 307

Importantly, some individuals do not report to law enforcement authorities not out of a concern for their safety; they shun police protection due to disgust with the prospect of police involvement in their personal lives or due to their experience with police disregard of gay-related cases. One interviewee, GD, expressed a pronounced unwillinguess to rely on the police for protection: "I have absolute contempt for the police. I will not deal with them.... I have Alarmed Response burglar systems [a private security firm] and they're under specific instructions from me never to call the police to my home."2308

The alienation of a class of people from the regular modes of police enforcement is especially alarming in the South African context. South Africa has one of the highest crime rates in the vorld. ${ }^{309}$ Thus, the defiant attitude expressed by individuals like GD is particularly profound. Of course, GD's attitude betrays class privilege; he has sufficient resources to rely on private security and burglar alarm systems. Lesbians and gays with fewver socioeconomic resources at their disposal are even more vulnerable. They stand outside the law, not simply im symbolic terms but in terms of physical security on a daily basis.

\section{B. After the Abolition of Sodomy Laws}

In October 1998, the South African Constitutional Court struck down the country's sodomy laws. ${ }^{310}$ Many people had anticipated this result, ${ }^{311}$ such that related social changes were already underway at the time of the Court's decision. In this section, I present findings based on follow-up interviews conducted in Spring 1999.312 On balance, the data support the conclusions in the previous discussion, with one possible exception (the

307. BW, at 18 .

308. Interview with GD, supra note $225, \uparrow 21$.

309. South Africa: U.S. Policy and Bilateral Relations: Hearing before the House Int'l Relations Comm. Subcomm. on Afr., FED. NEwS SERV., Oct. 14, 1999 (statement of Susan Rice, Assistant Sec'y for Afr. Affairs) ("South Africa's rate of violent crime remains among the highest in the world."); Almost Half of $S$. Africans Fear for Safety, XInhUa News Agency, Feb. 27, 1988 ("Most South Africans view crime as a grave threat to the country's well-being and almost half the population fear for their personal safety, according to a survey."); Institute for Security Studies, Crime Index, Vol. 2:1 (Jan.-Feb. 1998), available at http://www.iss.co.za/Pubs/Crime\%20Index/Volume2-1/contents.html (last visited Mar. 1, 2001).

310. Nat'l Coalition for Gay and Lesbian Equal. v. Minister of Justice, 1998 (12) BCLR 1517 (CC); see supra text accompanying notes 203-207 (discussing the Court's decision).

311. See, e.g., South African Court Erases Sodomy Laws, Houston Chron., Oct. 10, 1998, at A25; Interview with TQ, supra note 225 , 11 ("1 wasn't expecting other than what we got anyway. I didn't see how it could be anything other than that.").

312. The first set of interviews occurred after the new interim Constitution was established, with the sexual orientation nondiscrimination clause already included. Hence, during the first stage of field research, people's lives were already affected by that overarching constitutional enactment. 
issue of coming out ${ }^{313}$ ). In the following discussion, I analyze four broad areas that indicate attitudinal and behavioral shifts: (1) attitudes about the priority given to decriminalization; (2) sense of individual and community openness in public places; (3) relationships to the police; and (4) effects from the process of change itself.

\section{Decriminalization as the First Priority}

The deep political support, among lesbians and gays, for the lesbian and gay rights coalition's decision to tackle sodomy laws first suggests the importance of the criminalization issue in these individuals' lives. I asked each interviewee whether he or she agreed with the decision to prioritize the decriminalization effort given other arguably more pressing concerns affecting the lesbian and gay community, such as custody, insurance benefits, and marriage. Nearly every interviewee supported the decision to combat sodomy laws first. ${ }^{314} \mathrm{DR}$, for example, stated: "I think that sodomy in all its symbolic implications represents for people not just anal penetration but intimacy, and certainly the sodomy laws look at homosexuality as literally being something that was disgusting, something that was unnatural." 315 One interviewee, who was involved in the political decision to prioritize the decriminalization campaigu, explained his view:

I went along with that. A lot of politically minded people had come together and decided that it was important strategically to make

313. The evidence on the coming out process was mixed. A crisis counselor and a psychologist who both work with gay patients each made a point of stating that their clients have had no less difficulty with the personal trauma of coming to terms with their own sexuality. One interviewee described the coming out process in the following manner:

My counseling and clinical experience of working with lesbian and gay men in terms of coming out is no more or lcss traumatic then what it was $10,15,12,8,9,5$ ycars ago. Coming to terms with your sexual identity is still an issue ... and changing a few laws here and there is not going to make the crisis of that experience more diminished.

Interview with SS, ๆ 3, in South Africa (March-April 1999) (on file with author); Interview with DR, I 6, in South Africa (March-April 1999) (on file with author) ("But, certainly on an individual basis, with some of my clients that hasn't been an issue. The coming out process is still very similar to what it was."). On reflcction, it appears their statements concern people coming out to themselves; that is, dcaling with their own sexual identity. Others I interviewed reported that many more people had been coming out publicly in a relatively smooth process. The picture of this social phenomenon is blurry. One interviewee, for example, described his own difficulties in drawing a conclusion: "It's a bit difficult with me, because my coming out and the Constitution is sort of quite close together ... but 1 don't know if that's got more to do with me than my personal story." Interview with WJ, 95 , in South Africa (Mar.-Apr. 1999) (on file with author).

314. Some did not: "I assumed that was one of these funny legal gamcs that I don't understand ... 1 really don't know what they were trying to do except waste timc and money. Maybe some lawyer needed a new car." Interview with TQ, supra note 225 , ๆ 3.

315. Interview with DR, supra note 312 , ף 15. See also Interview with $\mathrm{BD}$, ף 4, in South Africa (Mar.-Apr. 1999) (on file with author) ("The reason why it was important was . . because it became visible. It was important to tackle issues that were visible."); Interview with WJ, supra note 313, ๆ 7 ("It secmed to make sense. Trying with the most obvious and glaring discrimination and start with that."). 
sure that the sodomy laws were scrapped. We are a minority that defines ourselves by our sexual practice. So I assumed that would be something of a priority. ${ }^{316}$

$\mathrm{BD}$, a black lesbian woman, who knew the laws did not strictly apply to women, said: "The reason why it was important was . . . because it became visible. It was important to tackle issues that were visible. We wanted them to recognize our relationships first." ${ }^{\text {317 }}$

These statements suggest that individuals received a sense of placement in the broader community through the legal change. A few individuals explained their belief that the crimmal laws were the first legal burden to combat because that initiative focused on the heart of the normative matter: repulsion of homosexual sexual practices. These statements were particularly significant because the individuals did not highlight concerns with respect to direct legal effects of the law, such as its potential enforcement. Some interviewees' support for the decriminalization efforts rested on the empirical assuniption that the change in the laws would dimimish stigma and reform the general public's perspective. Regardless of the accuracy of that assumption, the adherence to it demonstrated a sense of stignia already being lifted, and hope for positive social interactions to be given a fresh start.

\section{Openness in Public}

All of the interviewees described the public climate as having significantly improved, and several attributed this, in part, to the change in the criminal laws. These attitudes were often expressed in reference to a new freedom to be open in public spaces, with the threat of the laws lifted. A crisis counselor for lesbian and gay men, however, explained a dichotomous reaction:

I think for some of my clients... it was a matter of feeling relief . . . it was like, 'at least, you know I couldn't be bust [sic] for that by the cops or it couldn't be used agamst me.' But as far as my personal social network was concerned, it was neither here nor there. ${ }^{318}$

When asked to describe the difference between his social network and his clients, he explained:

The social network that I move im, well, it's like those laws never affected them in any case .... But, one must look at the kind of social miheu I'm talking about. It's a largely gay, white, and [Asian], and middle class kind of cominumity of people who in

316. Interview with SS, supra note 312 , \1.

317. Interview with BD, supra note 315 , \4.

318. Interview with SS, supra note $312, \llbracket 3$. 
terms of police harassment and policing weren't really affected by those laws as homosexual black men. ${ }^{319}$

Other interviews cast significant doubt on the assessment that the laws' abolition did not affect white and Asian middle class males. A number of interviewees with these demographic characteristics stated that their sense of vulnerability had begun to dissipate. DR, a gay white psychologist, explained: "I think that ... it is far more different where the law is in your favor; in that what I was disallowed when I grew up could be allowed now. So now I can walk hand in hand with my lover." ${ }^{320}$ Other individuals described the changes as profound in scope, though sometimes subtle and subconscious for the individual person:

One of the things I've kind of noticed about human beings is that change tends to be greater and ... because the change tends to be greater you actually don't know you've actually changed your attitude about something and that's my feeling about a lot of issues in the gay society. If I talk to people today and I look at where they were a year ago, they actually don't realize they've actually come out. Often they think they're in the closet, but then you say to them "but you're around the road and you're actually holding hands"... So, I think in many areas that's what I'm sensingbecause we're adjusting. ${ }^{321}$

As indicated by these statements, the idea of being able to hold hands in public recurred in different individuals' comments. DR explained:

People walk around fundamentally saying, "I don't feel that frightened in terms of my legal persona." The legal persona and the legal issues are far more accessible ... and I [know this because] I'm quite involved with the subculture from a social point of view as well as from a professional point of view. ${ }^{322}$

On the other hand, IT, now in his mid-fifties, explained that he found it difficult to change his behavior, to relax or be open in public. He stated that his caution was, at this point, probably excessive, but described it as ingrained. ${ }^{323} \mathrm{He}$ expected this would be different for the young and for future generations..$^{324}$

Some individuals' attitudes concerning their neighborhood and local venues, in particular, changed, but this varied according to race and ethnic-

319. Id. ๆ 4 .

320. Interview with DR, supra note 312 , ๆ 14.

321. Interview with TQ, supra note 225 , ๆ 4.

322. Interview with DR, supra note 312 , ๆ 9.

323. 1T(2), I 5, in South Africa (Mar.-Apr. 1999).

324. 1d. 96 . 
ity. ${ }^{325} \mathrm{HR}$, who previously told a story of her neighbor summoning a police car while she was arguing with her partner outside her home, now stated:

As far as harassment from neighbors and police... I'm thinking that that changed a lot. But, in different communities it works differently. Maybe the [Asian] community doesn't have as much harassment. ... I'd say for the best part [Asian] people are in the middle. I know the Africans they do have a lot of harassment still. ${ }^{326}$

EM explained that in relation to neighborhoods and local public places, his and others' sense of "relative isolation" had significantly lessened. ${ }^{327}$ Even in conservative areas, gay bars appear to be increasingly integrated with straight individuals and heterosexual couples, ${ }^{328}$ and, as one interviewee put it, in neighborhood settings "gay identity is less important." "329

\section{Relationship to Law Enforcement in General}

Perhaps the most significant indication of transformation occurred in individuals' relationship to law enforcement. Some of these attitudinal and behavioral shifts also appear to be based on assumptions about changes within the police force itself. ${ }^{330}$ Regardless of the validity of the assumption, individuals had a very different set of perceptions and interactions with the police force than before, and in ways which were directly connected to the transformation in the criminal law. As one measure of attitudinal changes, in 1995, WJ had stated: "These laws against gays and lesbians contribute to my lack of confidence in the police force as impartial ... I regard them as violent thugs. ${ }^{9331}$ Without my directing him

325. Some interviewees were of the opinion that the clubs were also increasingly racially integrated. Interview with DD, \ 8, in South Africa (March-April 1999) (on file with author); Interview with DW, I 8, in South Africa (Mar.-Apr. 1999) (on file with author). However, those from black communities, or with direct links to black communities, disagreed. See, e.g., Interview with BD, supra note 315,15 ; Interview with SS, supra note 312,12 .

326. Interview with HR, supra note 249, f 2 . Strangely, at one point in the interview, HR told about an incident outside her home which occurred several years before, not realizing she had told me the "same" story back then. This time, however, in HR's recollection, the police ear had driven away without a care. Id. ๆ 5. In 1995, she had described the police officers actions as threatening. See supra text accompanying notes $249-251$.

327. Interview with EM, ๆ 5, in South Africa (Mar.-Apr. 1999) (on file with author).

328. Interview with AC, $\mid 6$, in South Africa (Mar.-Apr. 1999) (on file with author). AC noted:

[P] eople are feeling a lot more freer to come out, go to gay clubs, 1 mean, the one in Port Elizabeth a lot of straight people are starting to come as well, which is nice-heterosexual couples, single women, single guys who are confused (laughter). So, I think people are a lot more freer, like 1 say I can see visible [changes].

Id.; see Interview with TT, ๆ 6, in South Africa (March-April 1999) (on file with author).

329. Interview with EM, supra note $327, \uparrow 5$.

330. See Interview with SS, supra note 312, ๆ 16 ("I think institutions like the police are a military-like top-downward structure. If they are told you may not discriminate against gays, that comes from the top and that is what must happen, despite their personal prejudices."); $\mathrm{BD}(2), \mathrm{I} 14$ in South Africa (Mar.-Apr. 1999) ("Police in townships are more relaxed.").

331. WJ, 7 f $6,8 \mathrm{~m}$ South Africa (July-Aug. 1995). 
to his previous statement in his 1999 interview, WJ said: " 1 do think I am far more trusting of the police than before ... I [also] know if the police says anything, just report them, say 'what's your name, what's your number' and report them to the highest level."332

Like WJ, other interviewees also expressed newfound empowerment with regard to expecting and demanding fair treatment by the police in a range of situations. TQ explained that in his helping gay youths who are arrested for unrelated reasons,

I have noticed a dramatic change. When I've had to confront officers or gone to a station and said, 'That boy is going to be locked up. You have a right to do that, but he's gay, and I'm insisting therefore that he has a separate cell.' I have never had anybody moaning about that. They're more than happy to comply and separate them ... even if they're over eighteen. l've not had problems. ${ }^{333}$

Notably, some of TQ's statements indicate an inner strength built on resentment from the past:

I'm certainly not a very timid person and I suspect that I come across quite hard. And I would in a sense be doing that because I've had such an ordeal from the authorities. So when I'm standing there in a sense I'm saying I won't have you do to others what you did to $m e^{334}$

DR stated that in his view, the change is in a sense of having one's rights and dignity restored, which assists people in dealing with the police with the same power as other citizens and which assists lesbians and gays in reporting crimes committed against them. ${ }^{335}$ The absence of a fear of being arrested oneself simply for reporting a gay-related crime was, as to be expected, no longer present.

\section{The Process of Change Itself}

The 1999 interviews supported one of my initial hypotheses: measurable variations were not simply due to two types of regimes, one in which sodomy laws exist and one in which they do not; the fact and process of legal change itself makes a considerable difference. The transformation represented for many individuals the solidification of a long-

\footnotetext{
332. $\mathrm{WJ}(2), \mathbb{1} 5$.

333. Interview with TQ, supra note $225, \mathbb{7} 7$.

334. Id. \ा 8, supra note 225 .

335. Interview with DR, supra note 312, 丹 12. DR stated:

So there are cases where people will report depending how politicized they are and to what extent they believe their human rights ... have been violated ... but I think that people are beginning to recognize whatever happens in the context of violation ... that they can have recourse.
}

Id. 
awaited constitutional promise and heralded changes to come. People were elated, ${ }^{336}$ especially after an early legislative failure and the unexpected interference in the litigation by the Minister of Justice. ${ }^{337}$ For those who previously lacked a clear understanding of the law, the change signified a sweeping statement that all laws which had criminalized "homosexuality" were now invalid:

I think the awareness that I got is that all those things that apply no longer apply. So, it's basically you can do what you want. Not in the sense that you can go and screw whoever at anytime or any age or whatever. It's just a matter of things have changed and there's not an enforcement of just being with someone-that you could be arrested for sleeping with your lover-whatever applies to heterosexual community, that applies now to the homosexual community. ${ }^{338}$

The decision itself also provided opportunities for people to educate others, to discuss the issues soberly with family members and colleagues, and sometimes to seek and find approval. One interviewee, a law professor, uses the decision as a pedagogical tool for students in a regular course about equality. ${ }^{339} \mathrm{TT}$, a lesbian woman, performs a play for university students on gender violence. In open-ended discussions following a performance of the play, she explained, "We got into the whole question on sodomy," and several of the students, already familiar with the court's decision, discussed lesbian and gay issues approvingly. ${ }^{340}$ In terms of family relations, a number of interviewees remembered the very words their parents used when they first talked about the Court's decision. ${ }^{341}$ The event of the decision did not necessarily trigger accepting attitudes, but it created a unique opportunity for parents to provide strong and meinorable affirmation of their children.

The legal change in many people's minds stood as a new symbol, an index of lesbians and gays' social acceptance. For more practical purposes, it also erased doubt about the legal prohibitions on homosexuality and diminished related pragmatic concerns. These legal changes were among the few significant events that occurred during the brief period in which lesbian and gay individuals' hives improved substantially from 1995 to 1999. As mentioned earlier, the Constitutional Court's decision was the first major victory for lesbians and gays under the new Constitution.

336. Interview with $\mathrm{BD}$, supra note 315,72 ("The sodomy law does not affect me as a lesbian but it affects the men, the gay men. So for me, it was good because you get discriminated as gay and lesbian. ... It was a celebration and because our friends are all gay guys."); see also Donald G. McNeil, Jr., South Africa Strikes Down Laws on Gay Sex, N.Y. Times, Oct. 10, 1998, at AS.

337. See supra text accompanying notes 178-179.

338. Interview with DW, supra note $325, \$ 15$.

339. See Interview with WJ, supra note 313 , $\{$ f 4, 6 .

340. Interview with TT, supra note 328, II 2 .

341. Interview with WJ, supra note 313,72 . 
This, however, is far too superficial an explanation of law's relationship to broader social and cultural forces. The findings in this and the previous section indicate only the micro-level involvement of criminal laws in individuals' daily lives, in relative isolation from consideration of other competing macrosociological forces such as generalized homophobia and religion. It is important therefore to ground the above discussion in an understanding of the micro-macro link and of the limits and context of law. The next Part addresses those concerns.

IV

\section{The Macro-Sociological Dimension of Sodomy LaWs}

It would leave the story half told to discuss the influence sodomy laws have on social dynamics only at the micro-level of individuals' lives as described above. To understand the extent to which these laws impact social norms and individuals' behavior, we must examine their influence on macro-level social institutions as well. ${ }^{342}$ As leading cultural sociologists Richard Munch and Neil Smelser contend, "[b]oth microscopic processes that constitute the web of interactions in society and the macroscopic processes that result from and condition those processes are essential levels for understanding and explaining social life. ${ }^{p 343}$ In the case of studying criminal laws against homosexuality, and their relationship to the generation of social norms, this dual-level approach is especially important for a number of reasons.

First, the analysis which follows moves from a surface-level assessment of the symbolic and expressive function of sodomy laws to a more complete understanding of the dynamics and consequences involved. Social norms scholars commonly use sodomy laws as an example of law's expressive function. Their work, however, does not explain the mechanisms by which these laws infuse sociocultural understanding through dis-

342. For definitional purposes, micro-sociological inquiries may be described as primarily concerning the self and interactions with other people, whereas macro-sociological inquires concentrate on the institutional, cultural, and societal dimensions of authority and social control. Munch and Smelser offer this general definition of the two categories:

We see the micro level as involving encounters and patterned interaction among individuals (which would include communication, exchange, cooperation, and conflict) and the macro level as referring to those structures in society (groups, organizations, institutions, and cultural productions) that are sustained (however imperfectly) by mechanisms of social control and that constitute both opportunities and constraints on individual behavior and interactions.

Richard Munch \& Neil J. Smelser, Relating the Micro and the Macro, in THE MiCRo-MACRo LINK 356, 357 (Jeffrey C. Alexander et al. eds., 1987).

343. Id. at 385. See also Jeffrey C. Alexander \& Bernhard Giesen, From Reduction to Linkage: The Long View of the Micro-Macro Debate, in THE Micro-Macro Link, supra note 342, at 31 (agreeing with the argument made by theorists Peter Blau, Raymond Boudon, Dean Gerstein, and Niklas Luhmann, that in sociological work of this kind "the link between micro and macro must be made"). 
course and social institutions. ${ }^{344}$ The discussion which follows provides the theoretical foundation for analyzing the extent to which that expressive function influences other social institutions which, in turn, also shape social norms and discipline individual behavior. This approach provides an important additive to norms-focused research programs in terms of assessing the reach and depth of the expressive functions of laws.

Second, the macro-level assessment which follows is vital to contextualizing the findings and discussion of the micro-level dynamics analyzed above. Indeed, this Article's findings point to the significance of law in the management of lesbian and gay peoples' lives. Yet, in retrospect, this spotlight on law may raise more generalized concerns given that other social institutions generate homophobia and also directly threaten lesbians and gays. Religious conservatism, ${ }^{345}$ psychological discourse, ${ }^{346}$ demands of bureaucratic capitalism, ${ }^{347}$ and the mainstream media ${ }^{348}$ are also partly responsible for regulating the experiences of lesbian and gay people. Without a more thorough examination of these influences, a critic might reasonably object that I have given undue emphasis to the influence of the law.

I want to sharpen this criticism a bit more because I think it exposes a problem that stands to be corrected in a wide range of sociolegal studies mcluding law and sexuality scholarship. Framing this criticism in its strongest terms also allows me to define more precisely the conclusions reached by this Article, in that it provides the occasion to contextualize the place of sodomy laws in the overall social regulation of homosexual behavior. The discussion that follows can, therefore, help to resolve potential concerns about the emphasis given to law not only in this study, but in law and sexuality and in sociolegal studies more generally.

Let ine then sharpen this line of criticism by making the following point. Austin Sarat and Thomas Kearns have criticized contemporary sociolegal studies for adopting a "law-first" paradigm, privileging the role of law in determining social relations to the detriment of other sociocultural institutions. ${ }^{349}$ Consequently, the discipline of lesbian and gay lives must be explained by considering sodomy laws' involvement alongside other social

344. See, e.g., Kahan, supra note 13, at 421; Lessig, supra note 5, at 1013; Mazzone, supra note 12 , at 1041 .

345. See Didi Herman, The Antigay Agenda: Orthodox Vision and the Christian Right (1997).

346. See Edward Alwood, Straight News: Gays, Lesbians, and the News Media (1996); Peter M. Nardi \& Ralph Bolton, Gay-Bashing: Violence and Aggression Against Gay Men and Lesbians, in Social Perspectives in Lesbian and Gay Studies 412, $425-27$ (Peter M. Nardi \& Beth E. Schneider eds., 1998).

347. See David F. Greenberg, The Construction of Homosexuality 347-96, 434-54 (1988).

348. See Alwood, supra note 346.

349. See Sarat \& Kearns, supra note 127, at 22. Sarat and Kearns take a strong position that the effect of both the constitutive and instrumental approaches to analyzing law "is to mute the interactive nature of the relationship between law and everyday life, to exaggerate the importance of state law and to discount society's nonlegal normative resources." Id. at 22. 
institutions that also pose a threat to lesbians and gays in public spaces and in their personal lives. For example, historian George Chauncey, in his renowned book on gay life in the early twentieth century, writes:

[T] he threat of extra-legal sanctions-of ostracism and the loss of jobs, family, and social respect-was a much more potent threat than the threat of judicial sanctions. Indeed, the policing of queer ways, and thus of normal ways, was most commonly effected through the informal policing of the streets, in gossip and in jeers and manhandling visited on men whom other men regarded as queer. ${ }^{350}$

Chauncey's point could apply to this Article's emphasis on the impact of sodomy laws. At bottom, Chauncey implicitly cautions that the conclusions reached about sodomy laws' social influences underestimate or leave unattended the strength of nonlegal institutions that also police and impose sanctions on homosexual behavior. This Part's discussion addresses that concern.

Below, I first discuss the unique potential of the constitutive approach to incorporate nonlegal forms of social norm construction into its conceptual model. Second, I examine two nonlegal institutions that have contributed to regulating homosexuality - religion and medicine - and discuss the role law plays within, because of, and despite these other institutional forces. Third, I suggest unique characteristics of legal authority, which contrast with religion, medicine, and other nonlegal forms of institutional authority in this particular area of social norm formation and maintenance. Before embarking on this three-part analysis, however, I should make clear that none of the following arguments should be interpreted as supporting the supremacy of law in the regulation and maintenance of social norms. Rather, the following discussion considers the contextual place of law in social norms management and evaluates what that place is in the particular context of sodomy laws.

\section{A. Sodomy Laws and Social Contexts}

In principle, the constitutive theory of law easily accommodates the view that various social institutions operate in life, working both for and against the law, to shape identity, regulate social relations, and influence personal behavior. In this regard, Sarat and Kearns's near wholesale criticism of the sub-field should be tempered. ${ }^{351}$ As Rosemary Coombe has remarked, scholars in constitutive theory "acknowledg[e] that law interacts with other forms of discourse and sources of cultural meaning to construct

350. George Chauncey, Gay New York: Gender, Urban Culture and the Making of GAY MALE WORLD, 1890-1940, at 25-26 (1994).

351. See supra text accompanying note 349 . 
and to contest identities, communities, and authorities." ${ }^{352}$ Constitutive approaches to law are neither incapable nor adverse to acknowledging and incorporating nonlegal forms of institutional authority. On the contrary, constitutive theories can take account of these other influences on social relations as long as the theorists themselves are sensitive to the relevant issues and information.

In terms of the present project, acknowledging and understanding the significant role of other social institutions is almost impossible to avoid. It is difficult to approach any sociological discussion of sexuality while ignoring the inultiple institutional forces that interact to regnlate (hoino)sexuality. The prevailing view in sociology holds that the social organization of sexuality is the historical product of a combination of institutional discourses. ${ }^{353}$ The most basic building blocks of sexuality (such as the classification of people as heterosexual and homosexual and the assignment of nornative content to those categories) are considered to be the result of "intersubjectively negotiated social and historical productsthat sexuality was, $\mathrm{m}$ a word, constructed."354

This generally accepted view of the "social construction of sexuality" has been credited in large part to the work of Michel Foucault. ${ }^{355}$ In $A$ History of Sexuality: Volume One, Foucault gave an account of various nonlegal institutional discourses that have resulted in the modern understanding and regulation of sexual identities. Pointing to the late nineteenth

352. Coombe, supra note 111 , at 794 .

353. See, e.g., Eve Kosofsky Sedgwick, Epistemology of THe Closet 2 (1990) (discussing the "[n]ew, institutionalized taxonomic discourses-medical, legal, literary, psychological" that impact on homo/heterosexuality); Jefrrey Weeks, Sexuality and its Discontents: Meanings, Myths \& MODERN SEXuALITIES 181 (1985) ("[P]ower relations addressing sexuality operate through a multiplicity of practices and apparatuses (medicine, psychology, education, the law), each of which has its specific structures of regulation."); see also Steven Epstein, A Queer Encounter: Sociology and the Study' of Sexuality, in QUEER THEORY/SOcIoLogy 145, 145-46 (Steven Seidman ed., 1996) (describing the consolidation of social constructionism school within the sociology of sexuality).

354. Epstein, supra note 353, at 145.

355. Of course, the social constructionist understanding of sexuality was not simply the brainchild of Foucault. "Yet to some recent studies of sexuality working outside sociology," one commentator colorfully remarks, "the concept of social construction is assumed to have sprung, like Athena, fully formed from the head of Michel Foucault." Id. at 146. Prior to Foucault, sociologists in the traditions of labeling theory and social interactionism had already begun the theoretical groundwork for the social construction of sexuality. See, e.g., Kenneth Plumier, Sexual Stigma (1975) (exemplifying symbolic interactionism); Mary McIntosh, The Homosexual Role, 16 Soc. Pross. 182 (1968) (exemplifying labeling theory).

Still, Foucault's work has carried the day. The extent of his contribution is demonstrated by the willingness of leading scholars to use his work as the launching pad for their own projects. See, e.g., SEDGWICK, supra note 353, at 3 ("[Foucault's] results 1 will take to be axiomatic ...."); DAVID M. Halperin, SaInt Foucault: Toward a Gay Hagiography (1995) (as the title suggests, performing a veritable hagiography of the man); Thomas, supra note 64. Cf. Kenneth Plummer, Afterword: "The Past, Present, and Future of the Sociology of Same-Sex Relations," in Social Perspectives IN LESBIAN AND GAY Studies 412, 425-27 (Peter M. Nardi \& Beth E. Schneider eds., 1998) (dubbing, as the "Foucauldian Deluge," one of the two main intellectual trends in sociology of sexuality through the 1980's). 
century, Foucault explained that scientific discourses and modern concerns with the health and distribution of populations contributed to the identification and acceptance of "a new specification of individuals" ${ }^{356}$ : homosexuals. Yet, even here Foucault mentions law's involvement in the transformation:

As defined by the ancient civil or canonical codes, sodomy was a category of forbidden acts; their perpetrator was nothing more than the juridical subject of them. The nineteenth-century homosexual became a personage, a past, a case history, and a childhood, in addition to being a type of life, a life form, and a morphology, with an indiscreet anatomy and possibly a mysterious physiology.... The sodomite had been a temporary aberration; the homosexual was now a species. ${ }^{357}$

This organization of sexual identities, resulting from multiple, intersecting institutional discourses, forms the cultural field in which laws against homosexuality operate. Sodomy laws would not have the ability to regulate certain behaviors without this conducive cultural terrain. As the discussion in Part III reveals, sodomy laws are able to function in the social world because of a ready community of onlookers who receive these laws and act, or have the potential to act, on the law's symbolic statements and punitive sentiments. Additionally, sodomy laws would not affect a particular "type" of individual without an already settled classificatory system that distinguishes people according to their sexual orientation and assigns them normative markers (such as "sick," "normal," "wholesome," or "profane"). Accordingly, sodomy laws should be viewed as functioning within and because of various other institutional discourses, such as religion and medicine, that mark, regulate, and censure homosexual behavior and identity.

In considering such interrelations, we should neither elevate nor underestimate the influence of law in the formation of these other institutional domains. John D'Emilio argues that the "making of a homosexual minority" in the United States cannot be understood apart from the inner workings of an "ideological configuration of sin, sickness, and crime. ${ }^{3358}$ Indeed, these three realms of sin (religion), sickness (medicine), and crime (law) have historically worked to reinforce one another, producing structural sexual inequality. For our purposes, however, it is useful to consider the processes by which the third domain, law, aids and abets the other two. In the following discussion I address, first, the case of law in religion and, second, the case of law in medicine.

356. FOUCAULT, supra note 123 , at 42.

357. Id. at 43.

358. John D'Emilio, Sexual Polmics, Sexual Communities: The Making of a Homosexual Minority in the United States 1940-1970, at 129 (1983). 


\section{B. Law in Religion}

Sodomy as "vice" underpins both religious concepts of sin and legal concepts of criminality. While religious beliefs reinforce the law's stance against homosexuality, anti-gay religious convictions are theinselves prompted and legitimized by the law's criminalization of homosexual acts. In political terms, the state's condemnation of same-sex practices is perceived to be highly important to religious leaders in spreading the word against homosexuality. At least in their view, abandonment of these laws would constitute an erosion of the(ir) moral universe and a threat to the preservation of anti-gay beliefs within the community. ${ }^{359}$ The law's stance is thought to represent the sentiment of the general community. Thus, without law's condemnation, religious leaders are less able to convince their followers that their message reflects the cultural mainstream and is protective of current standards of "moral decency."

As a more general matter, religious texts are subject to interpretations that reflect the sociocultural norms of the time; law plays a constitutive role in shaping those underlying sociocultural understandings. According to historian John Boswell, popular Christian beliefs over the past centuries have, depending on the period selected, either tolerated, condemned, ignored, or celebrated same-sex sexuality. ${ }^{360}$ Boswell's point is that religious beliefs are not the originating source of intolerance against gays, but the repository for other sociocultural structures that give rise to anti-gay sentiments. ${ }^{361}$ Therefore, law may play a constitutive role in producing and shaping those cultural norms. This is especially true of laws that are believed to codify popular revulsion and meant to exert moral influence. ${ }^{362}$

Legal discourse also affects the substance and strength of religious mobilization over homosexuality. Some scholars have discussed the use and consequence of rights rhetoric in lesbian and gay social moveinents. ${ }^{363}$ In an insightful study, Didi Herman has employed this approach to examine the use and consequence of rights rhetoric in the mobilization of anti-

359. See HERMAN, supra note 345 , at 185-87.

360. John Boswell, Christianity, Social Tolerance, and Homosexualtty: Gay People in Western Europe from the Beginning of the Christian ERa to the Fourteenth Century passim (1980).

361. For a discussion of what Boswell means by the transhistorical existence of "gay" people, see John Boswell, Revolutions, Universals, and Social Categories, in HIDDEN FROM History: Reclaiming THE GAY AND LesBian PAST, supra note 137, at 17.

362. Boswell states that "[n]ot until 533 did any part of the [Roman] Empire see legislation flatly outlawing homosexual behavior, even though Christianity had been the state religion for more than two centuries." Boswell, supra note 360 , at 171 . After 533, if one agrees that law takes on a constitutive role of its own, reversing religious anti-gay sentiments would have likely been a more difficult goal to accomplish.

363. See, e.g., Janet Halley, Gay Rights and Identity Imitation, in The Polrtics of LAw: A Progressive CritiQue (David Kairys ed., 3d ed. 1998); Brigham, supra note 114, at 421, 439, 449, 460 (1998). 
gay religious conservatism. ${ }^{364}$ According to Herman's findings, the new religious right is mobilized not by the rhetoric of "disease and seduction" but rather by rhetoric regarding the place of lesbian and gay sexuality under the law. ${ }^{365}$ This shift of focus to the legal arena has expanded, mobilized, and radicalized the religious right's constituency. ${ }^{366}$ As such, laws on sexuality influence the membership of religious movements and the content of their message.

As evidence of an internal shift within religious discourse, Herman's study includes a content analysis covering a forty-year period of Christianity Today, the leading American conservative Protestant publication. ${ }^{367}$ Herman identifies specific shifts in response to an emergent importance of the legal realm in the contemporary cultural struggle over homosexuality. Herman explains, for example, that Christianity Today "continued to print news reports on gay activism. Whereas previously these items had centered upon developments within the church, by the 1980s the journal covered gay rights struggles generally, as well as the response to those demands made by local conservative Christians." 368

Herman examines how the religious right's understanding of and attitude towards homosexuality has bcen shaped by the move into the legal realm. As a general trend, she describes the religious right's rhetorical transition from "old moralists," who based anti-gay sentiment on "disease and seduction," to "new pragmatists," who base anti-gay sentiment on "liberalistic rights rhetoric." ${ }^{369}$ She also emphasizes that these groups became especially invested im promoting the idea of homosexuality as mutable in order to fend off legal change: "[T]he CR [Christian Right] has proceeded against gay rights, rightly or wrongly, on the understanding that if people think homosexuality has a biological foundation then the CR will be less likely, and less able, to stand in the way of protective law reform." ${ }^{370}$ In short, laws concerning homosexuality have shaped the rhetoric and practices through which religious discourse constructs and responds to lesbians and gays.

\section{Law in Medicine}

The criminalization of homosexual behavior has also infiuenced the medical profession's apprehension of same-sex desire, including the origin

364. HERMAN, supra note 345 , passim.

365. Id. at 18 .

366. Id.

367. Id. at 25 .

368. Id. at 52 .

369. Id. at 18 .

370. Id. at 74; see also id. at 72 ("On a practical level, the CR came to perceive the immutability question as a crucial political use, largely because the mainstream lesbian and gay rights movement had made it so."). 
and strength of the pathological model of homosexuality. ${ }^{371}$ Medical discourse on homosexuality figures prominently in Foucault's history of sexuality and in other more recent works in the field. ${ }^{372}$ Scholars also agree that the medical profession's initial view of homosexuality has contributed significantly to the historical mistreatment of lesbians and gays. ${ }^{373}$ Therefore, exploring the relationship between the criminal regulation of homosexuality and the medical discipline is critical to understanding the complex matrix of regulations governing lesbians and gays.

It bears emphasis that the pathological model of homosexuality is not a subject simply of historical note. The American Psychiatric Association's (APA) widely publicized decision to drop "homosexuality" from the list of official mental disorders in 1973 did not, in fact, entail a clean break from the pathological modeI. ${ }^{374}$ The decision itself was strongly opposed by professional associations of psychoanalysts, ${ }^{375}$ members of which continued to conduct research projects, publish articles, and treat individual patients without discarding their conviction that homosexuality constituted a mental disease. ${ }^{376}$ Additionally, the decision to drop hoinosexuality from the list of psychological disorders was followed by the introduction of a new pathological condition entitled "Gender Identity Disorder of Childhood" ("GID"). GID basically pathologizes the gender non-conformity of effeminate boys and masculine girls. As Eve Sedgwick has argued convincingly, GID has been used as a device to target lesbian and gay children before

371. The pathological model holds that homosexuality is per se a mental illness, such as a mental disease or psychological disorder.

372. See, e.g., Homosexuality: Research Implications for Public Policy (John C. Gonsiorek \& James D. Weinrich eds., 1991) (collection of essays on psychology, social issues, and homosexuality); WeEks, supra note 353; Eve Kosofsky Sedgwick, How to Bring Your Kids Up Gay, 29 Soc. Texr 18 (1991).

373. See, e.g., Kenneth Plummer, Homosexual Categories: Some Research Problems in the Labeling Perspective of Homosexuality, in THE Making of THE MOdern Homosexual 53, 53 (Kenneth Plummer ed., 1981) ("One of the key forces in shaping a 'homosexual type' has been the process of medicalization. In declaring homosexuality a 'disease' and a 'sickness'-albeit in diverse ways-the psychiatrists and physicians effectively found a way of separating out and controlling homosexuality."). The medical discourse on homosexuality is one of the three realms D'Emilio identifies as the ideological configuration of gay subordination. See supra text accompanying note 358 .

374. In 1973 the American Psychiatric Association (APA) decided to drop "homosexuality" from the list of mental disorders listed in the Diagnostic and Statistical Manual. TASK Force ON Nomenclature \& Statistics, American Psychiatric Association, Diagnostic and Statistical MANUAL of Mental Disorders (3d ed. 1980). The change was incorporated into the International Classification of Diseases. Charles Silverstein, The Origin of the Gay Psychotherapy Movement, in A QueER WorLd, 358, 360 (Martin Duberman ed., 1997). Notably, the new diagnostic manual (DSM-III) did refer to homosexuality under another rubric, "ego-dygnostic homosexuality," a diagnosis for people specifically troubled by their homosexuality. No similar category existed for people troubled by their heterosexuality. "Ego-dygnostic homosexuality" was dropped in the revised edition of DSM-IIl. WorK Group to Revise DSM-III, American Psychiatric Association, Diagnostic and Statistical Manual of Mental Disorders (3d ed., rev. 1987).

375. Silverstein, supra note 374 , at 360 .

376. Id. 
they reach adulthood. ${ }^{3 n}$ Furthermore, prominent members of the psychiatric community continue to proffer the view that homosexuality is a developmental disorder in need of repair. ${ }^{378}$ Finally, the popular effects of the pathological model are still with us; many people consider homosexuals to be "degenerates" or "perverts," that is, generally mentally unfit. ${ }^{379}$

377. Eve Kosofsky Sedgwick, How to Bring Your Kids up Gay: The War on Effeminate Boys, in TENDENCIES 154, 157 (1993) ("American psychiatry is simply engaged in a long, subtle process of reconceptualizing homosexuality as a mental illness with another name-the 'gender identity disorder of childhood.'") (quoting Lawrence Mass, Sissyness as Metaphor: A Conversation with Richard Green, 1 Homosexuality \& Sexualtry 213, 214 (1990) (quotations omitted)); see also Elvia R. Arriola, The Penalties for Puppy Love: Institutionalized Violence Against Lesbian, Gay, Bisexual and Transgendered Youth, 1 J. GENDER RACE \& JUST. 429, 456-68 (1998).

378. See Francis J. Beckwith \& John F. Peppin, Physieian Value Neutrality: A Critique, 28 J.L. MED. \& ETHICS 67, 74 (2000) ("[T]here are many psychiatrists who believe strongly that homosexuality is an illness and should be treated as a psychiatric disease."); Daniel W. Hicks, President of the Assoc. of Gay and Lesbian Psychiatrists, Psychiatric News, Jan. 19, 1998 (Letter to the Editor) (stating that "there are still many mental health care practitioners who see homosexuality as pathological" and describing some as "practitioners [who] see themselves as moral advocates who must uphold the denigration of homosexuality" and other as "clinicians who, in sympathy with the pain of their homosexual patients' dilemma of living in a homophobic society, try to 'change' the sexual orientation of those persons"). One organization, the National Association for Research and Therapy of Homosexuality (NARTH), was founded in 1992 to promote the view that homosexuality is a disorder to be cured with reparative therapy. The American Psychiatric Association recently issued a Position Statement strongly criticizing the work of NARTH. See APA Board of Trustees, COPP Position Statement on Therapies Focused on Attempts to Change Sexual Orientation (Reparative or Conversion Therapies), available at http://www.psych.org/pract_of_psych/copptherapyaddendum83100.cfm (Mar. 2000). Others have dismissed the organization as a "fringe of the mental-health establishment." John Leland \& Mark Miller, Can Gays "Convert"?, NewsweEk, Aug. 17, 1998, at 46, 49 (quoting Gregory Herek, research psychologist at University of California, Davis). Nevertheless, the threat is real. NARTH's Board of Officers includes professors of psychiatry at the Albert Einstein School of Medicine, the University of California at Davis, and the University of Kansas. See NARTH, Narth Officers, at http://www.narth.com/menus/officers.html (last visited Jan. 25, 2001), and the organization boasts a study of 206 psychotherapists who practice "sexual reorientation therapy." NARTH, Available Resources, available at http://www.narth.com/menus/reso.html (last visited Jan. 25, 2001). Furthermore, an electronic joumal, published by the Christian Leadership Ministries, features articles by psychiatrists who subscribe to the same principles as NARTH. See, e.g., George A. Rekers, Gender Identity Disorder, J. Hum. SeXuALITY, available at http://www.leaderu.com/jhs/rekers.html (last visited Mar. 15, 2001). Dr. Rekers is the Research Director for Child and Adolescent Psychiatry and Chairman of the Faculty in Psychology at the University of South Carolina, School of Medicine. See also David B. Cruz, Controlling Desires: Sexual Orientation Conversion and the Limits of Knowledge and Law, 72 S. CAL. L. Rev. 1297, 1300 (1999) ("Despite the dismissal of 'homosexuality' as a mental illness by professional organizations, conversion efforts did not disappear from the scene and . . . are even enjoying a current resurgence in national attention. One reason for their persistence is that some mental health professionals still believe that lesbians and gay men are mentally disordered."); Laura A. Gans, Inverts, Perverts, and Converts: Sexual Orientation Conversion Therapy and Liability, 8 B.U. PuB. INT. L.J. 219, 220 (1999) (describing NARTH as part of a wider trend).

379. For example, a police officer at the University of Nevada, Las Vegas, responded with the following statement to a campus-wide email announcement on Coming Out Day: "'Please be advised that many [most of us] deeply resent your unauthorized use of the university net system to promote this form of mental illness. You wish to belong to the above group, fine. Stop wasting my tax dollars with this trash."' Stacy J. Willis, Campus Hate: UNLV Cop Posts Anti-Gay E-mail; Students, president, panelists shout down police officer's message that homosexuality is a mental illness, SALT LAKE TRIB., Oct. 24, 1998, at A12. See also Sen. Lott: Homosexuality Is Like Addiction, Mental Illness, SALt LAKE TRIB., Jun. 16, 1998, at A1 (reporting Senate Majority Leader Trent Lott's statement that gay people 
Laws against homosexual conduct are implicated in the original conception and subsequent development of the pathological discourse on homosexuality. As a historical inatter, the early sexologists who designated the homosexual (or "mvert") as "a medical case" were inspired to do so by the state's use of sodomy statutes. Admittedly, their project had progressive underpinnings as they sought to replace criminal sanctions with clinical treatment. ${ }^{380}$ Nonetheless, the ability to designate this "new specification of individuals" as "deviants" worthy of cure and treatment was enabled by the criminalization of the subject. Social historian Jeffrey Weeks explains that the designation of homosexuality as a pathology emerged, in large part, out of the regulatory pursuit of homosexuality through law:

The sexologists translate[d] into theoretical terms what [we]re increasingly being perceived as concrete social problems.... The growing refinement in the legal pursuit of the perverse, with. .. new secular offences, lead[] to a controversy over the cause of homosexuality ... and consequently over the efficacy of legal control. ${ }^{381}$

The benevolence of the early sexologists soon gave way to a conservative movement in psychiatry which sought to discipline and punish ${ }^{382}$ the sexual wrongdoers. ${ }^{383}$ Sodomy laws had enabled this institutional legitiniacy to emerge and implicitly supported such clinical diagnoses.

should receive treatment "just like alcohol ... or sex addiction ... or kleptomaniacs"); Rivera Live (CNBC television broadcast, Oct. 21, 1998) (confronting Reverend Jerry Falwell on his reference to Ellen DeGeneres as “Ellen DeGenerate"); Rivera Live (CNBC televison broadcast, June 22, 1994) (Doctor Howard Hurwitz of the Family Research Council, stating that the "homosexualist is psychopathological ... mentally ill. Each and every one of you is psychopathological, going back to Freud, Menninger, Bethe, Sacarates. I read this stuff."). The notion that homosexuality is a mental illness also serves as the underlying premise of the "ex-gay ministries," the religious right movement that argues lesbians and gays should undergo conversion therapy. Hanna Rosin, Crusade Turns Gays to the Straight and Narrow, WASHINGTON PosT, July 31, 1998, at A1 ("The conversion theorists attribute homosexuality to early childhood traumas, such as sexual abuse-one modern conversion therapist asserts that 85 percent of lesbians were molested as children."); Religious Groups' Ads Target Gays, AP ONLINE, 1998 WL 6696086, July 16, 1998 ("The Christian Coalition and more than a dozen other religious groups have launched a national anti-homosexuality campaign with newspaper ads that describe it as a sin and a mental illness.").

380. WEEKS, supra note 353 , at 71,250 .

381. Id. at 75. Weeks explains that sexologists were called upon to help achieve effective legal control of homosexuality, which gave sexology significant social influence and subtly helped shape the discourse towards pathologizing the homosexual. Id. at 75-76; see also id. at 79 ("Early sexology, then, drew much of its claim to legitimacy from its association with more acceptable institutions of power, especially medicine and the law, and this is a tendency that has continued.").

382. Charles Silverstein, Psychological and Medical Treatments of Homosexuality, in Homosexuality: Research Implications for Public Policy, supra note 372, at 101-02 (arguing both that "psychiatric diagnosis of deviant sexuality is also a form of punishment" and that so-called treatment was used by psychiatrists to impose punishment for violation of social rules).

383. Cf. D'EmILIO, supra note 358, at 18 (describing how the medical profession's original intention to "wrest power over the fate of homosexuals and lesbians away from the criminal justice system" was a project that backfired). 
Sodomy laws have also reinforced the ontological universe of anti-gay psychiatry by promoting certain conceptions of agency and blame. The state's punishment of individuals for committing crimes against nature carries a subtle message: these are practices people can and should change. At an institutional level, psychiatrists have been able to take up a similar charge, trying to subdue these deviants' sexual transgressions and return them to heterosexual normalcy. At a personal level, individual therapists have been (and still often are) influenced by the background illicitness of homosexuality. Gerald Davidson argues that "this salient feature of [the lesbian or gay patient's] personality-because it is negatively sanctioned ...-colors the clinician's perceptions," leading the clinician to conclude that the patient's psychological disturbances are related to his or her sexual orientation. ${ }^{384}$ In some psychiatrists' minds, the fact that lesbians and gays are lawbreakers confirms that homosexuality is associated with asocial tendencies, another sign of a generalized psychological disorder. ${ }^{385}$

Finally, law's role in producing a demeaning and hostile environment for lesbians and gays indirectly supported the earlier psychiatric community's conclusion that homosexuality was a mental illness. Psychiatrists who studied homosexuality as a pathological condition reasoned (and later argued) that the poor mental health and social mal-adjustment of lesbians and gays confirmed that homosexuality constituted a generalized mental disorder. A paradigmatic example of this line of thinking is Irving Bieber's Homosexuality: A Psychoanalytic Study of Male Homosexuals ${ }^{386}$ the leading textbook on homosexuality for many years ${ }^{387}$ and the subject of favorable coverage by numerous popular newspapers and periodicals when it was first published in $1962 .{ }^{388}$ Bieber and his colleagues explained that the inherent mental instability of male homosexuality was evidenced by the fact that "[w]e found many homosexuals to be fearful [and] isolated." 389 The authors also suggested that gay men were destined to be unhappy ${ }^{390}$ and that attempts at long-term relationships were inherently futile. ${ }^{391}$ Not taken into account by the authors was the fact that many gay men would

384. Gerald C. Davidson, Constructionism and Morality in Therapy for Homosexuality, in Homosexuality: Research Implications for Public Policy, supra note 372, at 143.

385. See Katz, supra note 151 , at 185.

386. IrVing Bieber et al., Homosexuality: A PsychoANal ytic Study (1962).

387. Kenneth Lewes, The Psychoanalytic Theory of Male Homosexuality 206-07 (1988) (explaining that Bieber's monograph was "the most influential and lasting work of this period ... and it continues to be read and taught in psychopathology courses in universities"); D'EMILIo, supra note 358 , at 144 (explaining that Bieber's text was one of the two "most widely discussed books about the subject emanating from the scientific community in the $1960 \mathrm{~s}$ ").

388. D'EmILIO, supra note 358 , at 162.

389. BIEBER ET AL., supra note 386, at 254.

390. Id. at 317 .

391. Id at 318 . 
predictably feel "fearful [and] isolated" due to a generally hostile legal and social (including psycho-pathologizing) environment. Furthermore, the subjects of Bieber's and other psychoanalytic studies were often lesbians and gays who had either committed themselves or who were otherwise in the custody of the medical or criminal justice system. ${ }^{392}$ One should expect this set of individuals to suffer disproportionately froin emotional problems both associated and unassociated with their sexuality.

\section{Sodomy Laws in the Contemporary Social Field}

While my discussion has considered law's role in institutional discourses that have contributed to gay oppression, progressive developments in these other nonlegal domains may also work to counteract the constitutive power of laws against homosexuality. Importantly, the psychological discourse on sexuality has made a sharp enough break from its past to pose a challenge to the prohibition and regulation of lesbian and gay peoples' lives. ${ }^{393}$ There have also been progressive developments in theological discourse on sexuality. ${ }^{394}$ The lesbian and gay movement has made advances

392. John C. Gonsiorek, The Empirical Basis for the Demise of the Illness Model of Homosexuality, in Homosexuality: Research Implications for Public Policy, supra note 372, at 120-21 (criticizing the validity of earlier studies whose "samples were often drawn from legally or psychologically involved homosexuals").

393. The APA decision to drop homosexuality from its list of mental illnesses was profoundly important. Silverstein explains: "The publicity around the event also encouraged many gay people to come out, as if the APA gave them permission to disclose their sexuality to friends and family. For gay men who hated their homosexuality, the announcement was like an elixir that restored self-esteem and confidence." Silverstein, supra note 374, at 363 . The APA decision was also soon followed by the Association for the Advancement of Behavior Therapy (AABT), which issued a resoundingly positive statement on homosexuality. See Davidson, supra note 384 , at 138 (reproducing the statement of the AABT). The APA has also since issued its own boldly progressive policy statement. See American Psychiatric Association, Position Statement on Homosexuality, 150 AM. J. Psychiatry 686, 686 (1993). The symbolic victory in the APA's decision to remove homosexuality from the list of mental disorders seems to have not been disturbed by the sub rosa introduction of GID. Those who criticize the introduction and use of GID have done so, in part, to bring attention to an issue which has otherwise escaped public scrutiny. See supra text accompanying note 377.

394. The new Catechism of the Catholic Church does not retreat from condemning homosexual acts as "intrinsically disordered." CATHOLic ChuRCH, CATEChism of THE CATHOLIC ChuRCH 566, 7 2357 (1994). However, the Vatican also denounces "unjust discrimination" on the basis of homosexual orientation:

The number of men and women who have deep-seated homosexual tendencies is not negligible. They do not choose their homosexual condition; for most of them it is a trial. They must be accepted with respect, compassion, and sensitivity. Every sign of unjust discrimination in their regard should be avoided. These persons are called to fulfill God's will in their lives and, if they are Christians, to unite to the sacrifice of the Lord's Cross the difficulties they may encounter from their condition.

Id. at 566, ๆ 2358. A recent statement by the United States Catholic Bishops also counsels Catholic parents to "accept and love" their sons and daughters because "homosexual orientation (is) experienced as a given, not something freely chosen" and "by itself, a homosexual orientation cannot be considered sinful, for morality presumes the freedom to choose." United States Catholic Conference, Aliways Our Children: A Pastoral Message to Parents of Homosexual Children and Suggestions For Pastoral Ministers, 1997. There are even cracks appearing within the Southern 
in and through other social institutions as well, ${ }^{395}$ which ultimately allows for further resistance to the social effects of legal prohibitions. I believe it would be wrong, however, to conclude that these "counter discourses" offer sufficient resistance to negate law's regulatory force. To the extent that nonlegal discourses and social relations produce a visible and viable lesbian and gay community, sodomy laws take on a different hue of social regulation.

First, progressive trends in these other directions mean that law's sanction becomes a more significant variable in the equation. As other regulatory social institutions recede, law assumes greater primacy. Second, the progressive developments in other realms create a better, yet uniquely disturbing, situation in which lesbians and gays are visible, but remain the direct targets of criminal law. Had the other institutional discourses remained the same, lesbians and gays might have been more receptive to certain aspects of law's constitutive effects, such as internalizing law's message, remaining completely closeted, and seeking professional "treatment." However, sodomy laws in the modern era operate within a social field in which many lesbians and gays have access to a broader community, enough structural support for long-term partnerships, and a strong sense of self-worth. In this context, sodomy laws lose some of their constitutive capacities and instead operate more as a direct threat of potential violence. On the one hand, sodomy laws are thus less subtly constitutive of identity and function more effectively as a blatant exercise of regulation. On the other hand, the effects of sodomy laws still continue to shape the boundaries of social interaction, concepts of security, and expectations of many lesbians and gays.

In this respect, it is probably best to distinguish between law's constitutive role in the formation of sexual identity and law's regulatory effect once those identities are relatively settled. With regard to the latter, the findings discussed in Part III.A detail the exercise of legal power in regulating the conduct of lesbians and gays. At least by their own accounts, many lesbians and gays report that sodomy laws are a significant factor in a range of mundane decisions. As discussed earlier, this complex of social relations in which sodomy laws operate may best be described as the disciplinary techniques of law exercised through social panoptics, and criminal sanctions empowered by dispersed public surveillance. If one focuses too narrowly on the former set of issues, issues of identity and community

Baptists. Blessing for Gay Unions, N.Y. TrMES, Nov. 17, 1998, at A18 (reporting that a local Baptist church has defied state and national Baptist conventions by permitting ministers to officiate at "blessing ceremonies" for same-sex couples).

395. See, e.g., ALwood, supra note 346 (documenting progressive advances in popular news media in the 1990s). 
formation, ${ }^{396}$ these disciplinary processes by which laws operate may be overlooked. ${ }^{397}$

From the perspective of law as a disciplinary and regulatory force, sodomy statutes should also be distinguished from nonlegal institutional discourses because of the unique ways in which this feature of legal force operates. Perhaps most importantly, law is backed up by publicly sanctioned violence. An mdividual may be resistant to the pressure of informal social sanctions, ${ }^{398}$ but law's punitive measures are not subject to such forms of avoidance. Specifically, an mdividual may have the willpower to resist imternalizing social opprobrium produced by religious discourse, media representations, and popular culture. ${ }^{399}$ This resistance, however, will be entirely futile im the face of the penalties imposed by law. Law also has a unique aura of legitimacy because its substantive mandates are generally presumed to be reflective of society's interests as a whole. ${ }^{400}$ Lesbians and

396. Lesbian and gay studies has focused great attention on the first set of issues: the social construction of homosexual identity and the contours of the lesbian and gay community. Ironically, some scholars who have criticized the preoccupation with the social construction of homosexuality tum instead to studying the social construction of heterosexuality. JONATHAN NED KATZ, THE INVENTION of HETEROSEXUALITY (1995).

397. In this regard, I wish to encourage a broader incorporation of Foucault's work on disciplinary power into sociolegal studies of sexuality. Foucault's multi-volume set on the history of sexuality has been the conceptual touchstone for lesbian and gay scholarship, while his other research interests have received significantly less attention. In a recent translation of his essays, Foucault explains that his delving into the history of sexuality constituted one particular axis of intellectual pursuit-"the modality of the relation to the self." Michel Foucault, Preface to the History of Sexuality, Volume Two, in Ethics: SUbJectrvity AND TRUTH 204 (Robert Hurley et al. trans., Paul Rabinow ed., 1997). Foucault distinguishes that intellectual project from another "axis-the relation to rules-that 1 wanted to explore using the example of punitive practices." Id. at 203. He explains that "[t]here was always the risk of producing, with regard to sexuality, forms of analysis focused ... on the techniques of control and coercion, as in my previous work on sickness or criminality." Id. at 204. However, there is also good reason to redirect attention to the forms of analysis relating to "the techniques of control and coercion" as they relate to sexuality. It is this latter area of analysis that furnishes significant insights into "the techniques for 'governing' people," $i d$. at 203, as opposed to discourses of the body and identity.

398. Chauncey, for example, critiques the tendency in lesbian and gay cultural studies to accede to "the myth of internalization." CHAUNCEY, supra note 350, at 4.

399. Compare, for example, Michele Dillon's ethnographic work involving Dignity/Boston, a local chapter of a lesbian and gay Catholic group. Michele Dillon, Carholic IDENTITY: BALANCING REASON, FATTH, AND PowER 115-63 (1999). Dillon's study reveals significant ways that individuals in Dignity/Boston adopt "strategies by which they disconnect their Catholicism from the authority of the church hierarchy ... [and] how they use their interpretive autonomy to reappropriate the symbolic resources of Catholicism." Id. at 116. The Catholic church involves an especially heirarchical structure of authority. Hence, the ability of these individuals to uncouple their own religious beliefs from the church's doctrinal views on sexual orientation-while still maintaining their personal connection to Catholicism-is a strong indication of the emancipatory freedom available in relation to religious discourse.

400. This popular view of the law shares a common thread with classieal sociological schools, such as Durkheim's view of law as the expression of dominant social norms. See LISA J. McINTYRE, LAW IN THE SOCIOLOGICAL ENTERPRISE (1994). McIntyre states:

From the Durkheimian perspective the relationship between social and legal norms is straightforward: Law emerges from social norms. Durkheim was not alone in his view. The 
gays are thus likely to believe that the law's stamp of disapproval reflects the sentiments of the general public, rather than the political interests of a vocal minority. Correspondingly, anti-gay members of the community who subscribe to this same understanding of the law (viewing law as the expression of public values, rather than constituting those values) are likely to feel emboldened in their antagonism to lesbians and gays. Sodomy laws thus have a far-reaching and self-reinforcing effect: they create the sense that criminal prohibition reflects widespread societal interests even though (1) those interests may only represent a small minority, and (2) those interests may be partly constituted by the law itself.

Law also defines the boundaries of civic community and the expected behaviors of citizenship. In the same manner as a religious community is defined by its relation to the scriptures, the civic community in which one belongs is defined by its public laws. In this respect, sodomy statutes carry a special impact: they shape one's relationship to the civic realm. Criminal sanctions, which brand people as outlaws, are sure to shape an individual's sense of civic identity. Indeed, the findings discussed in Part III reveal an internal schism within those lesbian and gay individuals who wish to view themselves as law-abiding members of society. This feature of the laws' effect is amplified when sodomy laws are interpreted as condemning not simply a sexual practice but a constitutive part of one's personal identity. Under a legal regime in which sodomy laws operate, many lesbians and gays consider themselves, and are considered by others, as second-class citizens. Some lesbians and gays may not internalize these sanctions. Instead, they simply lose respect for the civic community itself, feeling alien to this realm of communal relations.

Sodomy laws also shape the relationship lesbians and gays have with the police and, as a consequence, their general protection under the law. Police officers are quite literally "law enforcement agents," or in common parlance, "the law." As the discussion in Part III shows, lesbians and gays learn not to rely on the police for problems that arise in situations even tangentially related to their sexual identity. The way the law regulates public spaces also encourages lesbians and gays to socialize in relatively hidden and isolated places, ${ }^{401}$ especially because the police are not around. This of course increases their vulnerability. Many lesbians and gays thus may be said to frequent a sort of legal underworld, not unlike prostitutes, illegal immigrants, and drug dealers, which makes them especially

idea that law implements custom and social expectations and norms, and that it is not the other way around, is firmly embedded in both folk and scholarly wisdom. Id. at 97.

401. See Martin P. Levine, Gay Ghetto, in GAY MEN: THE Sociology of MALE HomosexualtTy 182 (Martin P. Levine ed., 1979); see also Laud Humphreys, Tearoom Trade: Impersonal Sex in Public Places (1975) (describing isolated locations selected by men seeking casual sex with men). 
susceptible to victimization and abuse. In many ways, this situation is nothing new. Chauncey reports that one commentator of gay New York in the 1890s and 1900s "repeatedly deplored the fact that such youths felt justified in brutalizing fairies. 'The thievishly inclined regularly prey on androgynes,' he noted, because they knew the latter were considered 'outlaws' by the authorities and thus would not dare complain to the police for fear of drawing attention to themselves." 402 In short, lesbians and gays stand outside the law and are, as a consequence, the subjects of continued victimization.

This Article has argued that to understand the effects of law in general, and criminal laws against hoinosexual acts in particular, one must take into account the law's role in a wider social context. This part of the discussion has examined the ways in which the criminalization of hoinosexual practices interacts with other forms of institutional authority, such as religion and medicine. I have suggested some ways in which sodorny laws exert influence within these other domains. More importantly, however, are the ways in which progressive developments in these other domains affect the constitutive power of sodoiny laws more generally. The inodern social context in which sodomy laws operate is shifting; we are witnessing a gradual erosion in the underlying structure of sexual inequality. The metaphor of the closet has less appeal today compared with a decade or so ago, and issues of lesbian and gay "culture," "community," and "identity" are more common in conteinporary discussion.

In this context, however, sodomy laws still seriously matter. Sodomy laws have lost some of their constitutive capacities, and instead operate more as a symbolic, if not direct, threat of state-sponsored violence. These laws also carry unique impacts compared with other social forces of regulation. Studying these unique impacts has been the principal endeavor of this project. In looking to those aspects of how sodomy laws matter, I have attempted to sidestep certain issues about identity and the individual's relationship to herself. Instead, I have attempted to move the scholarship's discussion of sexuality towards the study of rules affecting inembers of lesbian and gay communities, or in Foucault's words, "the techniques for 'governing' people." ${ }^{403}$ I have also specifically attempted to help dislodge the continued adherence to the enforcement principle in legal scholarship and judicial considerations of criminal laws against homosexuality. From an empirical standpoint, then, we can hope to better understand the force of legal power expressed through social relations and law's collateral effects on individuals, community, and social interactions. In Part V, I conclude by suggesting implications this study might have for future research agendas in social norms scholarship generally.

402. ChaunceY, supra note 350 , at 59 .

403. Foucault, supra note 397, at 203. 
$\mathrm{V}$

\section{Conclusion: Reflections on SOCIAL NoRMS ScholaRSHIP}

At the narrowest level, this Article has analyzed what I have called "the social experience of sodomy laws" in South Africa. More broadly, the Article details the "indirect" costs and benefits of these laws and, by extension, other criminal laws, whether enforced or not, which target an aspect of an individual's identity. In this discussion, I have attempted to make good on the promise to follow the new turn in social norms scholarship: to ground the analysis in qualitative and empirical research and to explore the ancillary effects of law beyond concerns related to enforcement. My objective has been to add to our lexicon of sociological understanding an analysis of how such laws "may, in fact, reconfigure-for better or for worse - the way that we perceive, think, desire, or interrelate with others and judge others. ${ }^{3404}$ In this manner, the project has endeavored to play a part in meeting the "need to explore, beyond the effect of social meaning on behavior (especially short-term behavior) [and study] the way that these practices shape us as subjects of our time." ${ }^{205}$ Based on the particular findings of this Article, as well as its use of the constitutive approach, I want to end with a few suggestions for designing research agendas in social norms scholarship more generally.

Before discussing these suggestions, I should add an important qualification: this Article has dealt with the regulation of activities that many individuals use to define their very identity-what may be called identitarian features of people's lives - and, for that reason, the application of my conclusions may be limited to those dimensions of life. Although this qualification may limit the project's application, it also has important benefits. The existing social norms literature generally fails to distinguish sharply between social norms relating to identitarian activities (such as belonging to a gang ${ }^{406}$ or refusing to duel in an honor society ${ }^{407}$ ) and social norms relating to less meaningful aspects of individuals' lives ${ }^{408}$ (such as cleaning up after your $\operatorname{dog}^{409}$ or wearing a protective helmet ${ }^{410}$ ). Insofar as my analysis is limited to laws that regulate identitarian aspects of life, the following suggestions may not apply as a categorical matter to normsfocused research agendas. This limitation, however, suggests that existing

\footnotetext{
404. Harcourt, supra note 8 , at 182.

405. Id.

406. See Kahan, Alternative Sanctions, supra note 6, at 612-15.

407. See Lessig, supra note 3 , at 682 .

408. See, e.g., id. at 667-72 (analytically proceeding seamlessly from examples of discrimination against the disabled, to abortion, to buckling seatbelts, to anti-smoking).

409. See Robert Cooter, Normative Failure Theory of Law, 82 CoRNell L. REv. 947, 976-77 (1997) (describing informal enforcement of pooper-scooper laws); see also Richard H. McAdams, The Origin, Development, and Regulation of Norms, 96 MicH. L. Rev. 338, 406 n. 225 (1997) (picking up Cooter's pooper-scooper example and running with it).

410. See Lessig, supra note 5, at 968.
} 
social norms models might need to be rebuilt so that this distinction between the two types of social norms is taken into account. In that regard, this Article indicates that the discussion of law and social norms should, at a minimum, appreciate the constitutive impacts of law which are peculiar to activities that individuals rely on to define themselves as opposed to those which are far less meaningful. With this qualification in mind, I suggest three contributions this Article offers for future norms-focused research designs.

First, social norms scholarship should attempt to incorporate deeper investigations of the processes that generate identities and group formations. Some social norms scholarship takes certain background structures as given, whereas constitutive sociological work such as the present one tries to uncover the dynamics underlying those structures. Mark Tushnet, for example, makes the following criticism: "The new Chicago school appears to have rediscovered the idea of reference groups and re-labeled it 'social meaning.' The interesting question, of course, is how people come to see other people... as a reference group whose disapproval matters to them." ${ }^{.411}$ In part, Tushnet's criticism is that the current literature does not adequately acknowledge questions of identity formation which precede preference formation. ${ }^{42}$ Tushnet concludes that the conceptual lacunae in social norms scholarship result from the limited use of sociological tools. ${ }^{413}$ If so, the constitutive approach has much to offer.

The findings in this Article help illuminate the processes by which laws influence the composition of, and relations between, social groups. For example, a rich literature already exists analyzing sodomy law's influence in the social construction of "homosexual" and "heterosexual" identities. ${ }^{414} \mathrm{My}$ research supplements that work with empirical findings related to sodomy laws' involvement in shaping the boundaries of civic commumity, attitudes toward the state, and relationships to public space. Along these dimensions, law may be said to help constitute inembership within

411. Tushnet, supra note 7, at 582-83. Robert Cooter models the shifting equilibrium of social norm development within and between groups (and law's potential for directing those changes). See Robert Cooter, supra note 6, at passim. Yet, he does not question how law might be involved in the definition and boundaries of the groups themselves and the reasons the relevant individuals come to evaluate each other according to normative criteria. Also, consider Lawrence Lessig's extended analysis of the use of imprisonment as a failed threat to prohibit gentlemen dueling. See Lessig, supra note 5, at 971-72 (discussing social meaning of imprisonment as a badge of honor within an honor culture). Lessig does not broach questions concerning the law's involvement in constructing and influencing the boundaries of the relevant social groups (for example, the "gentlemen"; the audience for their actions; and the honor culture) which precedes the law's involvement in constructing and influencing their preferences.

412. For a few scbolars, Tushnet's criticism is inaccurate. See, e.g., Cass R. Sunstein, Social Norms and Social Roles, 96 Colum. L. REv. 903, 962-64 (1996) (discussing law's involvement in deflning the boundaries of caste-based groups).

413. See Tushnet, supra note 7, at 582 .

414. See, e.g., Halley, Reasoning About Sodomy, supra note 83, at 1721. 
the group, the relation of the reference group, and the notions and salience of community. This line of inquiry should be important to social norms scholars. Studying law's potential to change social norms between and within groups without studying the law's construction of those groups themselves misses or obscures vital sociological information.

Second, norms-focused research agendas should take into account law's potential effects on the rate, distribution, and ease by which social norms are transmitted. Sodomy laws, to the extent that they affect the nature of one's community and other social relations, also affect the ways in which social norms are transmitted between and within groups. If individuals' relationships with family members are fractured, or if they feel significantly safer frequenting public places where police are not around, we should expect that the network of relations in which they are embedded will modify, or mediate, the ways in which norms are transmitted. For example, the connection between the "general public" and the lesbian and gay community, the relationships of lesbian and gay individuals to the civic realm, and the informal relationships lesbian and gay residents have with their neighbors, all affect the structural processes and mechanisms of norm management. ${ }^{415}$ For legal scholars and policymakers interested in compliance with social norms, these collateral and feedback effects are especially important.

Finally, the constitutive approach facilitates analyses of how norms are produced and transmitted through institutionalized discourses, such as medicine, law, and religion; work such as this Article can bring to social norms scholarship a richer understanding of the law's relation to the broader cultural production of social norms. Contemporary sociological theory has focused attention on the role these types of institutional practices play in the production of cultural knowledge. While constitutive projects need not work within this tradition, the constitutive approach is especially conducive to it. In Part IV, I discussed how sodomy laws, at a macro-social level, interact with other institutional discourses to produce an encompassing normative system regulating homosexuality. This discussion is meant to improve current theoretical models by revealing the structure of the underlying processes that transmit or resist law's expressive function, structures that often serve as the connecting fiber between law and social change.

415. For social norms scholarship that recognizes similar structural processes, though with a continued emphasis on enforcement of the law, see Tracey L. Meares, Social Organization and Drug Law Enforcement, 35 AM. CRIM. L. REv. 191 (1998) (arguing that high rates of incarceration of African American males fractures the very community-based social organizations that are needed to mediate positive social norms and promote local order); see also Transcript, The New Chicago School: Myth or Reality?, supra note 3, at 7-11 (presenting Meares's discussion of her ongoing research agenda concerning intermediary institutions (such as the church)). 
A feature the above suggestions share in common is that they all indirectly implicate issues of enforceinent: how law can efficiently and successfully influence social norm transformation. I have argued throughout this Article that such insights cannot be gained without empirical, and in this case ethnographic, research. By looking beyond issues of enforcement to indirect costs and benefits of particular laws in shaping society and individuals' lives, we can deepen and expand our understanding of law's relationship to social norms. This Article has attempted to solve one piece of that larger intellectual puzzle.

\section{Appendix A: Methodology}

The project relied primarily on ethnographic field research conducted at two separate intervals. The first set of open-ended, one-on-one interviews occurred in summer 1995; the second took place in spring 1999. Participants were selected according to a "snowballing technique." This metliod involves identifying primcipal, or initial, participants and spreading out from there according to additional contacts that those participants provide. The National Coalition for Gay and Lesbian Equality (NCGLE) assisted in identifying the primcipal participants. The NCGLE is an umbrella organization for lesbian and gay groups throughout South Africa. Although it is primarily a civil rights organization, its affiliates include social and community service organizations, sports groups, and youtli organizations. Representatives of local NCGLE offices in Johannesburg, Cape Town, Durban, and Port Elizabeth provided the initial contacts. Emphasis was given to achieving racial, gender, and other demographic diversity (sucli as residents of townships). Most of the principal participants were affiliated in some respect with the NCGLE-e.g., as members, clients, or friends of members of the organization. To balance this effect, principal participants were asked to identify potential interviewees wlio did not have a close connection to the NCGLE. The 1995 interviews consisted of 39 people; the 1999 interviews involved follow-up interviews with 80 percent of the participants from 1995.

The 1995 interviews focused on individuals' recent and ongoing experiences under South Africa's sodomy laws; whereas the 1999 interviews focused on the changes or lack of changes people experienced after the law's invalidation. Because the interviews were open-ended, although I asked the following series of questions, I also let the interview at tinies roam relatively free from these "conversation-starters." Many of the questions were also worded generally and were meant to provoke reflections on a specific subject. I would therefore follow some of these questions witl nore detailed questions tailored to the participant's response as the need 
arose. The 1995 interviews were divided into three thematic segments, with a series of questions under each:

A. Obtaining demographic and other personal information from each individual

1 . What is your occupation?

2. What is your age?

3 . What is your educational background?

4. What race do you consider yourself?

5 . What is your religion and what religion were you brought up with?

6. How do you self-identify in terms of your sexual orientation?

B. Discussion of individual's knowledge about the sodomy laws and recent changes

1. What is your understanding of the sodomy laws of South Africa, specifically

(a) are sodomy laws still in force?

(b) what do sodomy laws prohibit?

(c) what could happen to someone found guilty of violating the sodomy laws?

2. Did you always have these understandings of sodomy laws or did you previously have another understanding of what the laws meant?

3 . When did you first find out about the sodomy laws?

4. How have you received information about the laws (e.g., reading, wordof-mouth, school)?

C. Discussion of experiences under sodomy laws

1. Have people ever used these laws in expressions of prejudice or hatred towards you or in reference to gays and lesbians in general?

2. Did you reflect on these laws in relation to your coming out experience or views of your sexual identity?

3. Did these laws affect your understanding of yourself differently at various times in your life?

4. Have you ever had encounters with police or other officials with regard to these laws?

5. Has anyone ever threatened you, either explicitly or implicitly, with reporting you under these laws?

6 . Have these laws restricted your social life, for example

(a) restricted activities like publicly holding hands;

(b) restricted your ability to hold openly gay or lesbian parties;

(c) created difficulties in reporting abuse of a lover or sexual partner?

7. Have these laws affected you in your job, such as shielding your sexual identity from co-workers and employers? 
8. Have these laws affected your aspirations in seeking certain jobs?

9. Have you ever faced a form of blackmail because of these laws?

10. Have these laws affected your ability to organize or work for gay and lesbian rights?

11. Have these laws affected your involvements in political affairs in political groups in general?

12. Have these laws affected your access to services or financial opportunities, such as finding an apartment, receiving inheritance, house loans, custody suits?

13. Have these laws affected relations or discussions with family or friends and their response to your sexual orientation?

14. Have you ever owned or been in a place (such as a bar) whose operation was affected by these laws?

15. Have these laws ever affected where you've decided to live or go for a vacation?

16. Have you ever been assaulted or the victim of another crime and had these laws affected whether or not you reported the incident?

17. Have these laws affected your personal relationship with or view of the police?

The 1999 interviews were more open-ended and allowed participants to reflect specifically on statements they made in their previous interview. A number of routine questions, however, served as the basis for the inore general conversation. The 1999 interviews were divided into two thematic segments, with a number of set questions under each:

A. Discussion of understanding and response to invalidation of sodomy laws

1. When did you first learn of the Constitutional Court's invalidation of sodomy laws?

2. Have you read the Court's opinion or excerpts of the opinion? If so, where (for example, newspaper articles, the actual opinion on the Internet)?

3. Did you know that sodomy laws were being challenged in court before the Constitutional Court's decision took place?

4. Immediately after it happened, did you discuss the Court's decision with anyone outside of the gay community?

5. Did your understanding of what the laws prohibited change in learning about the litigation and the Court case? (Explain.)

6. How has or how do you expect the Court's decision to change your or other people's lives? 
B. Discussion of experiences since invalidation of sodomy laws

1. How have any of your experiences, that we discussed when we spoke before, when the sodomy laws existed, changed? (Follow-up with specific examples from previous interview and questions about when the change occurred.)

2. Have you felt more free in certain places such as bars since the laws were struck down or since we last spoke?

3. Have you felt differently in your relation with certain people since the laws were struck down?

4. Has your relationship to or views of the police changed since the change in the law? (Explain)

5. Have you discussed the invalidation of the sodomy laws with your parents or other family members?

6. Have you discussed the invalidation of the sodomy laws with people who you are not out to?

Most all of the archival rescarch for the project was conducted at the Cape Town office of the NCGLE and at the University of the Witwatersrand Law School. The NCGLE maintains a small documents library containing material in Afrikaans and English. Of greatest use were a collection of nation-wide press clippings, legal briefs and court material from recent civil rights cases, and publicity material used by the NCGLE and other gay and lesbian groups in the decriminalisation campaign. The University of the Witwatersrand was an essential resource for conducting background legal research. The university's law library maintains a collection of documents on the establishment of the new South African Constitution, law reports of old South African cases, and studies of Parliamentary Commissions in the last century. 